A.

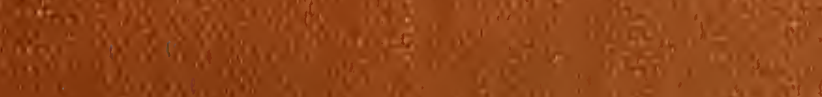

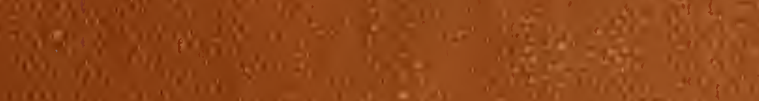

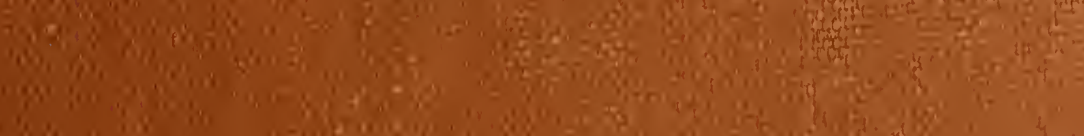

$n_{n}^{2}$

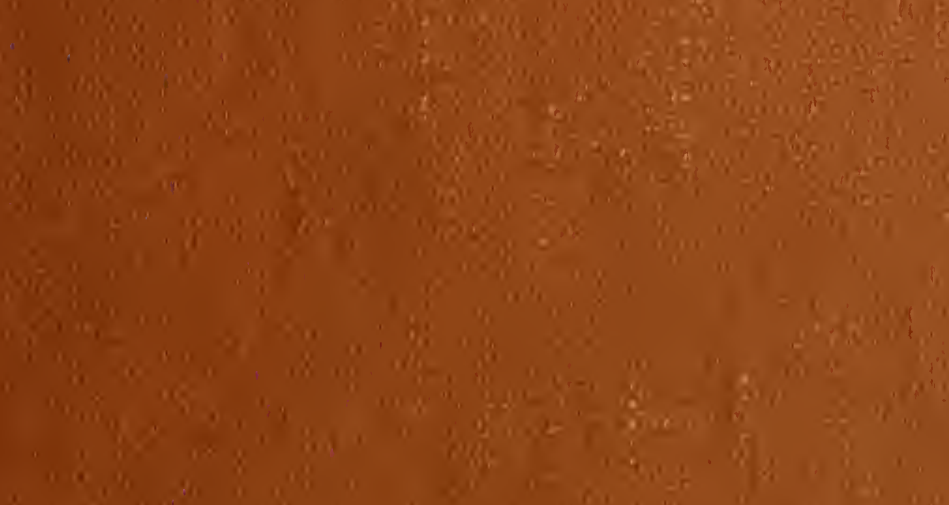

3
3

$20 y+2=0.020$

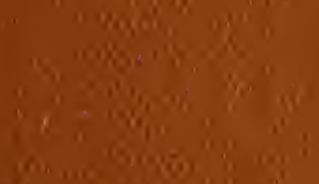

Whe

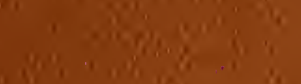

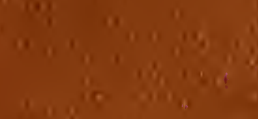

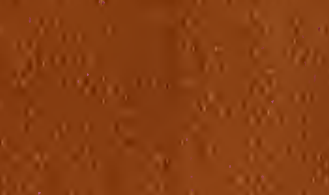

$\log _{0,3}, 250$

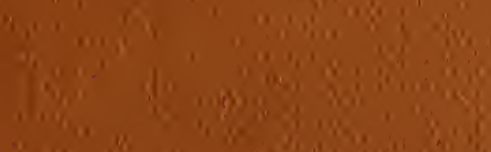

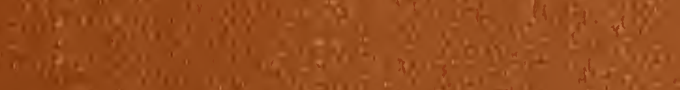

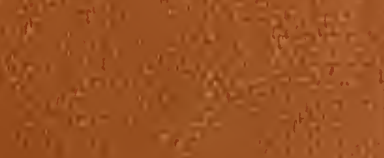

1.

Sh
$2: 28$

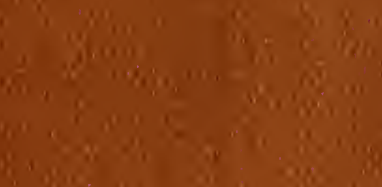

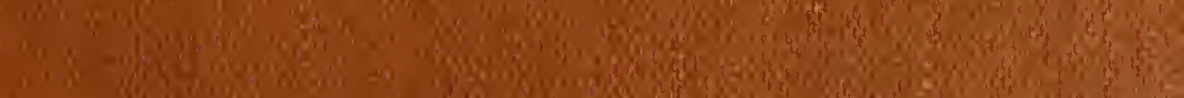
$x^{2}+x^{2}$

$\sin _{2} 2$

gow

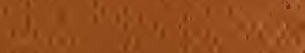

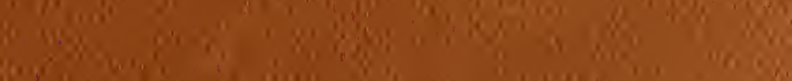
$\operatorname{lin}$

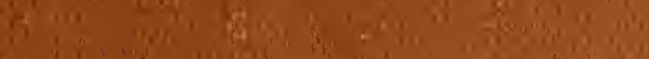

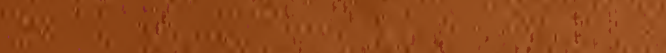

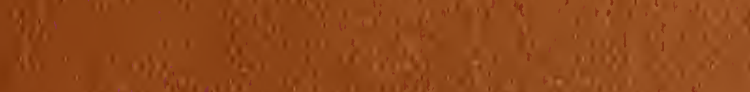

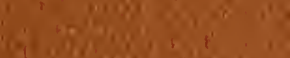

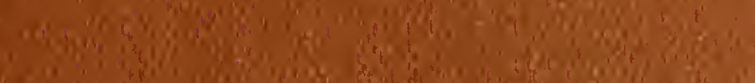
20.

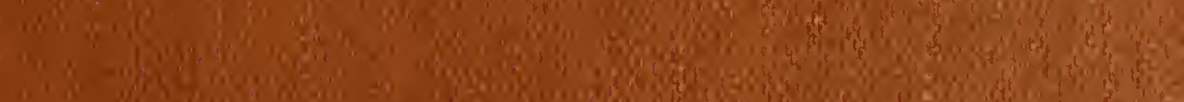

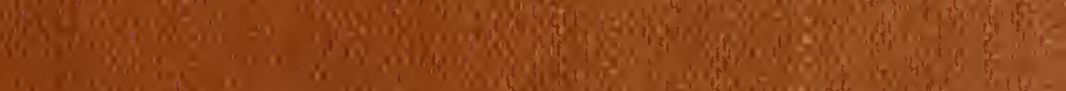
2.

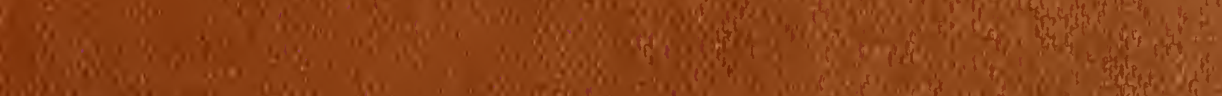

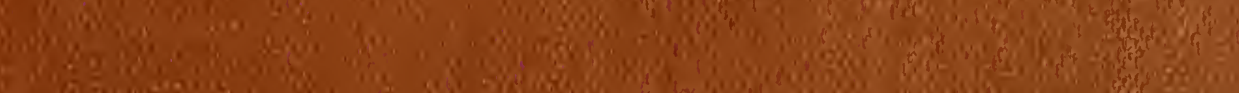
Qmi Whang

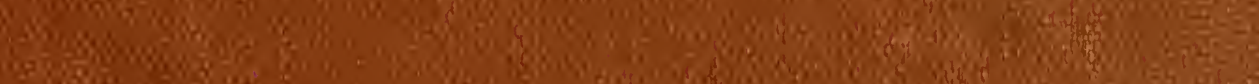

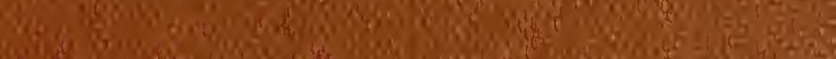




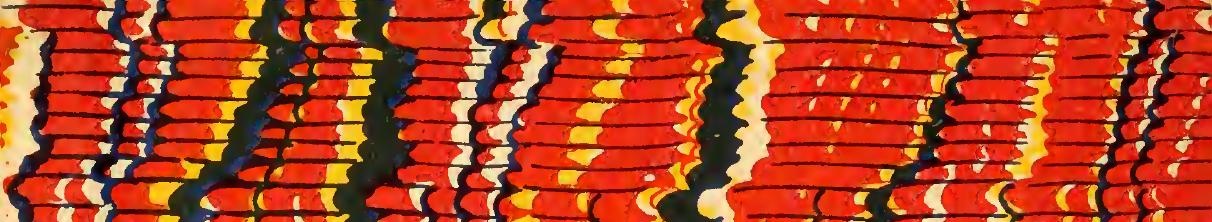
सिता तो है है? की

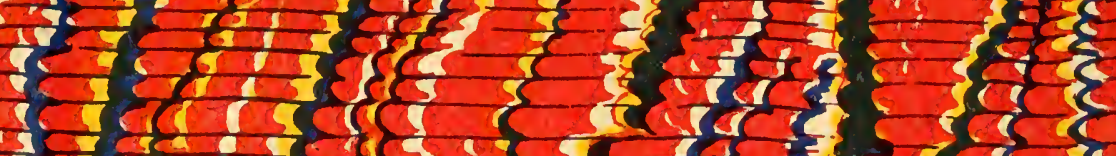

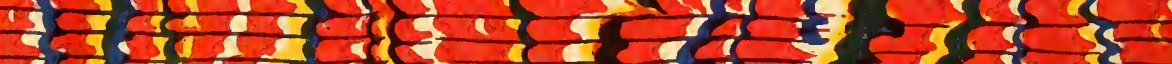

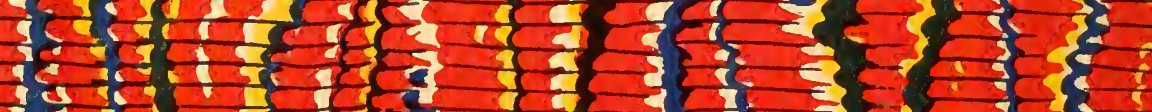

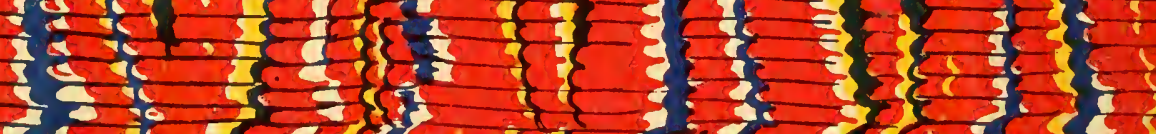

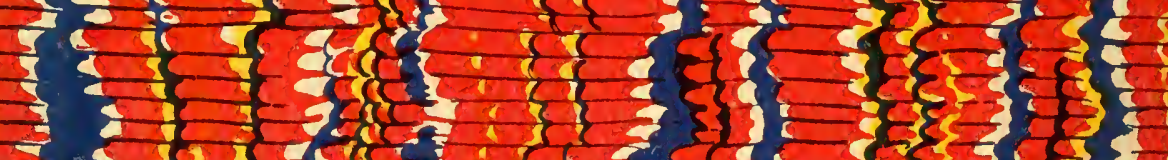

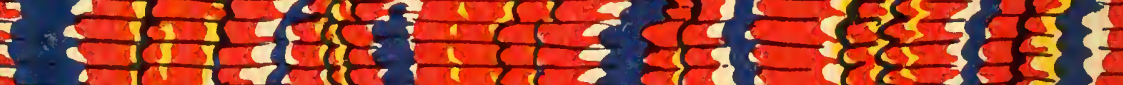

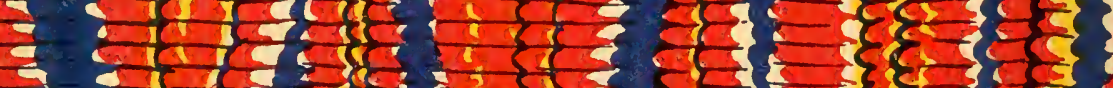

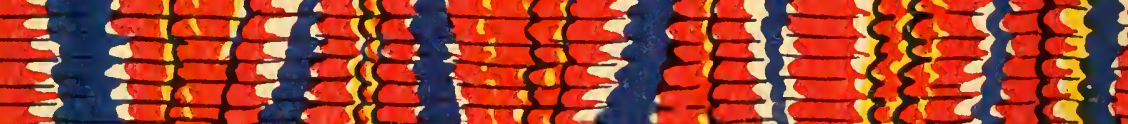

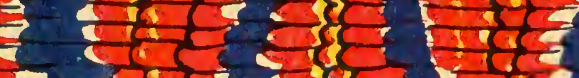

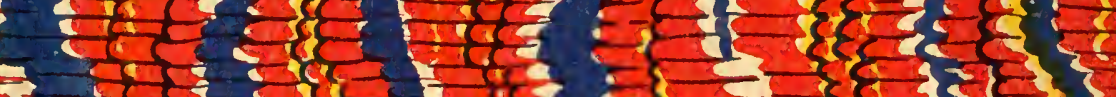

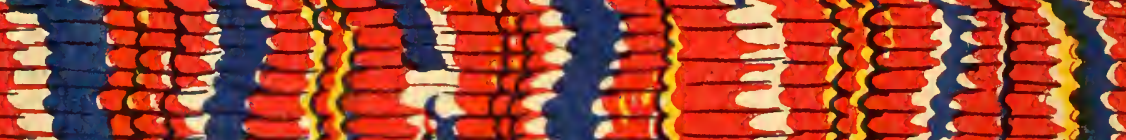

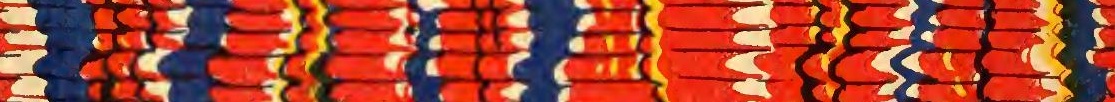

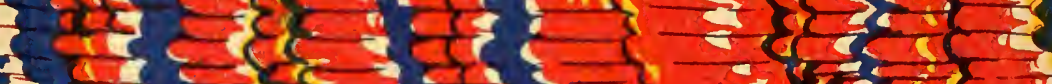

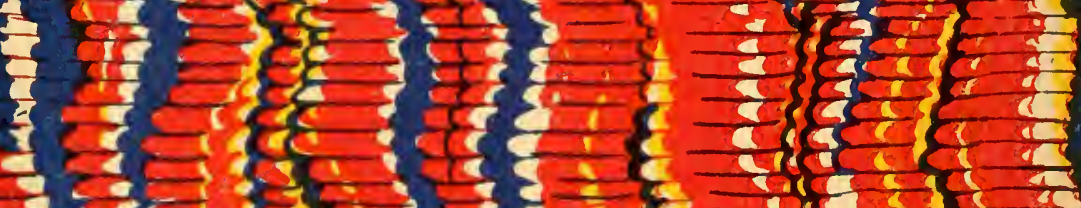

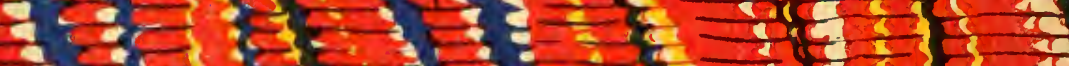

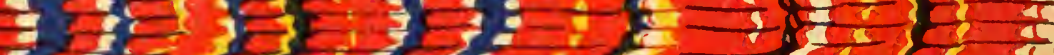

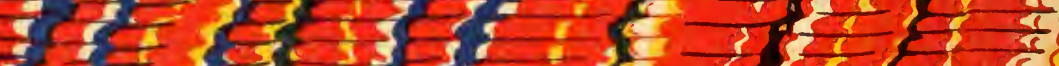

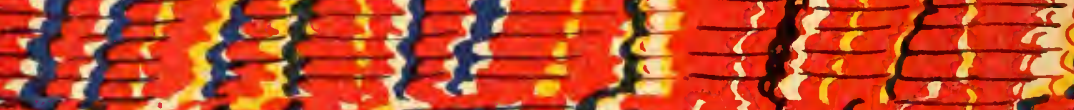

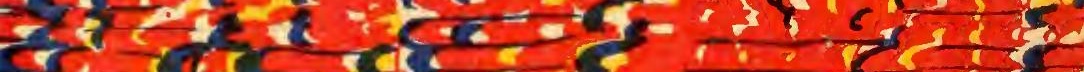

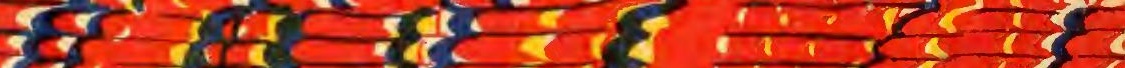

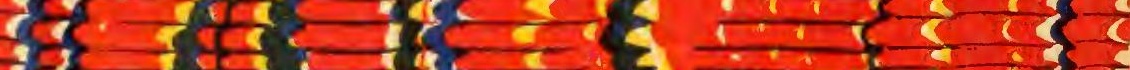

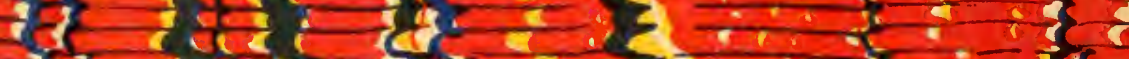

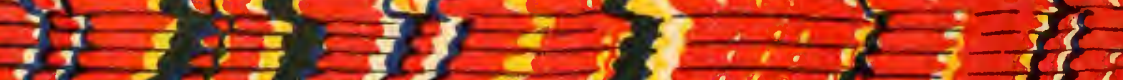
1
1

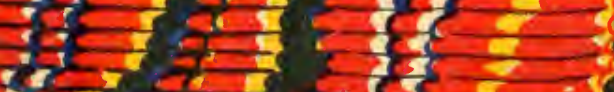

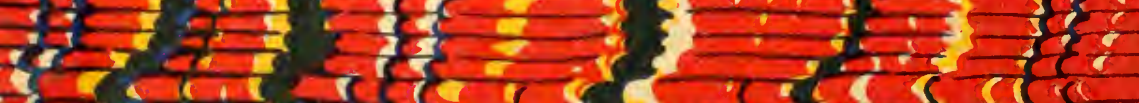

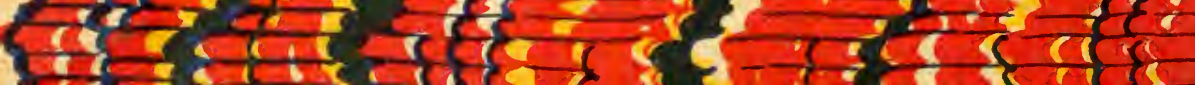







5 



\section{A \\ SYNOPTICAL LIST \\ OF THE \\ ACCIPITRES \\ (Diurnal Birds of Prey)}

Comprising Species and Subspecies described up to 1919, with their Characters and Distribution

BY

H. KIRKE SWANN, F.Z.S., M.B.O.U.

Corresponding Fellow of timer. Orn. Union.

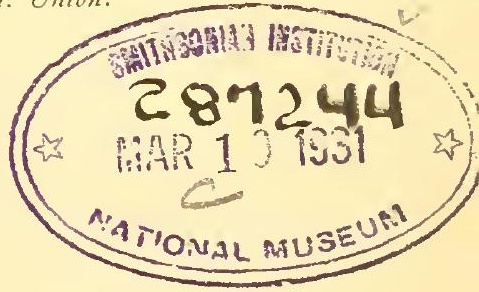

LONDON :

John wheldon \& CO., 38, Great Queen Street,

KINGSWAY, W.C.2 



\section{PREFACE}

In concluding my work on the Accipitres, a work which I fear has grown far beyond my original intention of publishing a mere list, I have to acknowledge my indebtedness to the sources from which I have received inspiration and help. In the first place I must acknowledge that a good deal of the systematic part and the generic characters have been borrowed from the late Richard Bowdler Sharpe's "Catalogue of the Accipitres in the Collection of the British Museum" (1874) of which his annotated copy, laid down on sheets and extended, came into my possession after his death, as also his interleaved copy of the Accipitres portion in Gray's "Genera of Birds," upon which he based his 1874 monograph. For permission to make use of the former work I have to thank the Trustees of the British Inseum. I have also derived assistance from Mr. W. L. Sclater's work at the British Museum (Natural History) in so far as his had preceded mine, and his MS. Catalogue of the skins, which he kindly gave me permission to use. I have also to thank Mr. Bannerman, Mr. Chubb and other assistants at the Museum for help rendered during my studies there. To Lord Rothschild and Dr. Hartert for the use of the superb collections at Tring I am grateful, and to Dr. Hartert especially for much personal assistance. The Rev. F. C. R. Jourdain and a number of other friends have also given me help and encouragement in various ways in what, although an arduous and unprofitable undertaking, will I hope be of some permanent help in systematizing this interesting group of birds. 



\section{wis is}

\section{N D E X TO GENERA}

An Asterisk (*) affixed indicates a change of name. Italics indicate a discarded name.

\begin{tabular}{|c|c|c|}
\hline Accipiter & 30 & Eutolmaetus \\
\hline Egypius ........... & 4 & Eutriorchis. \\
\hline Aquila $\ldots \ldots \ldots \ldots \ldots$ & 63 & \\
\hline Archibuteo....... & 53 & Falco \\
\hline Astur $\ldots \ldots \ldots \ldots$ & 19 & \\
\hline Asturina ... & 54 & Gampsonyx \\
\hline Asturimula... & 87 & $\begin{array}{l}\text { Geranoaetus.. } \\
\text { *Gymogyps. }\end{array}$ \\
\hline Baza ..... & 106 & Gypaetus .... \\
\hline Busarellus. & 57 & Gypagus ... \\
\hline Butastur . . & 88 & Gypohierax \\
\hline Bute & 40 & Gypoictinia.. \\
\hline Butengallus... & 57 & Gyps ....... \\
\hline Buteola ....... & 54 & \\
\hline Catharista & 2 & Haliæëtus. \\
\hline Cath & 2 & astur. \\
\hline Cerchneis & 144 & Harpa ... \\
\hline Circa & 76 & Hat \\
\hline Cire & 10 & yhaliactus \\
\hline Coragyps vice Catharista & 2 & $\begin{array}{l}\text { Harpyopsis } \\
\text { Helotarsus }\end{array}$ \\
\hline Diss & 161 & Henicopernis. \\
\hline Dryotriorchis . . & 76 & $\begin{array}{l}\text { Herpetotheres .. } \\
\text { Heterospizias . }\end{array}$ \\
\hline & 95 & Hieraaëtus .... . \\
\hline & 101 & Hieracidea . \\
\hline Erythrotriorchis & 39 & Hierofalco ........... \\
\hline
\end{tabular}


Ibycter .......... 8

Ictinaetus .......... 69

Pithecophaga ....... 78

Ictinia ........... 104

Kaupifalco ........ 87

Leptodon .......... 100

Leucopternis......... 58

Lophoaetus......... 74

Lophogyps .......... 6

Polioaetus.......... 164

Poliohierax ........ 118

Polyboroides......... 10

Polyborus .......... 7

Psendogryphus ....... 3

*Pseudogyps vice Gymnogyps.......... 5

Lophotriorchis ....... 69

Loptoictinia ......... 99

Regerhinus ........ 100

Rostrhamus ........ 99

Rupornis.......... 55

Machærhamphus ...... 111

Megatriorchis ....... 39

Melierax ........... 18

Micrastur .......... 15

Microhierax ......... 115

Milvago $\ldots . . . \ldots . .9$

Milvus ............ 96

Morphnus......... 61

Nauclerus .......... 95

Necrosyrtes......... 7

Neophron ........... 6

Nisaetus .......... 67

Nisoides... . . . . . . . 29

Otogyps........... 6

Pandion........... 162

Parabuteo.......... 17

Pernis ........... 112

*Sagittarius ....... 4

Sarcorhamphus $\dagger \ldots . . .1$

Serpentarins ......... 3

Spilornis .......... 79

Spizaetus.......... 70

Spiziapteryx......... 119

Spiziastur ........ 70

Tachytriorchis....... 52

Terathopius ........ 89

Thalassoaetus ........ 91

Thrasaetus ......... 62

Tinmmonculus ....... 144

Torgos .......... 6

Uroaetus ......... 63

Urotriorchis ........ 17

Urubitinga ........ 57

Vultur........... 4

+ Mr. Sclater (Ibis, 1919, p. 777, Auk, 1920, p. 154) points out that, if the rules are strictly adhered to, Vultur Linn. must replace Sarcorhamphus, while the logical result is that Vulturide must replace Cathartide and the Old World (or true) Vultures be called Egypida. 


\section{ADOEND. FT ('ORPIGENDA (PAL'T' I.)}

Page + No. $T$. In distrilution for S.E. and X.E. read : S. and $X$.

„ 4 , \&. To distril), adel: Himalayas, Afuhanistan.

.. ,. ., 9. For distrih, read: Plains of $\mathrm{X}$. Tullis.

, , „10. In distrib, delete: Abyssinia.

, di len. X. For Jorgos read: Torgos.

- "No. 14. For forgos read : Torgos.

. ,. 15. For Otogyps read : Torgos.

,. , , 17. To distrib. add: Canary Ls., Cape Verd Is.

.. 11 .36. 1n distrib. after Europe add: N.W. Afriea (Morocon).

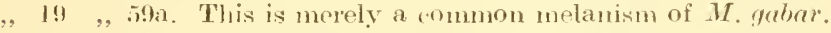

... .. Git. For Sileria read: IV. Asia (Asia Minor, Palestine, rete.).

. 20 , (in). To distrib, arkl: Japan.

.. .. .. Gill. For Astur yentitis condidissimns, ote. rewul : Astur gentilis allidus Menz. te.p. 4:3s (1SS:).

, $2: 3$. il. After this article add :

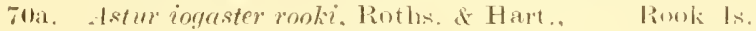

Nor. Zool., xxi.,p. 28s (1!14). (Admiralty [s.)

, 26 , 79a. Aftor this article add:

791. Astur clams robustus, Zeitz. S.I ()rn. Helville ls., 1,pt. I, p. 13(1914). N. Terr. Austral.

., 29) ,95. Aftes this article [ I cannot place from rleucription, as it seems immature] add :

9.5. Ister buergersi, Reichenow, Orn. M.l?. (ierman Хеw xxii., p. $29(1914)$

rinineil

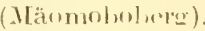

.. 311 .. 97. For N. Asia reatl : W. Asia.

,. . .

N. and Central

Asia from

Turkestan to

Japan: in

winter to Inlia. Kaslmire,

Assam, limtora.

:. 31 !h. For -tceipiter grami real: A. nisus granti.

.. ., . $99 h$. After this article insert :

9!c. Accipiter fuscus venator, Wetmore, Pr. Porto Ricon.

13iol. Soc. Wash. xxvii., p. 119 (1914).

.. :3: , 102a For pP. 171-6, read : p. 173.

1025, Delete the word: Minullus.

Does not appear to be a tenable species, however: and is most probably a melanism of No. 63a, Astur tachiro sparsimfasciatus.]

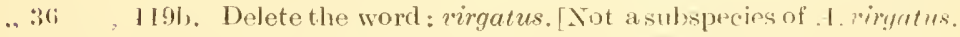

, 37 .. I1!d. Not separable from No. 119 . (Hartert).

.. 1.; 16 To be cancellerl and following leaf sutstitured : 



\section{ADDITIONAL SPECIES AND SUBSPECIES.}

29a. Milvago chimachima cordata Bangs and Panama. Penard, Bull. M.C.Z., Ixii., pp. 25- (1918).

30a. Milvago chimango temucoensis IV. Sclat., Bull. S. Chile. B.O.C., xxxriii., p. 43 (1918). [Palal, near T'emuco, prov. Cantin, type in B.M.]

52a. Climacocercus plumbeus (W. Selat.), Bull. N.W. B.O.C., xxxviii., ]. 44 (1!1S). [Carondelet, Eenador. Rio Bogota, pror. Esmaruldus, type in B.M.]

54c. Geranospizias carulescens baliurents W. Ecuador Sclat., Bull. B.O.(., xxxviii., p. 44 (I!) IS). (Gnayas [Bulzar Mllus., Guyes Prov., type in B.M.] Prov. \& P'una I.)

63d. Astur tachiro tenebrosus Lönnberg, Arelı. f. Brit. E. Zool., xi., No. 5, 1. 2 (1917). [Lomliani, Africa. B.E.A.]

123a. Accipiter bicolor schistochlamys Hellmayr, Bull. W'. Ecuador. B.O.C., xvi., D. ¿2 (I906). [Nanegul, W. Ec., type in Tring Mus.]

125a. Accipiter beniensis Lömberg, Areh. f. Zool., E. C'ongo. x., No. 24, p. 13 (1917). [Beni.]

158i. Rupornis magnirostris insidiatrix Bangs and Colombia. Pellard, Bull. M.C.Z., lxii., 1p. 25- (1918).

166a. Leucopternisghiesbrechti costuricensis WV. Sulat., Nicaragua. Bull. B.O.(1, xxxix., p. 76 (1919). [Carillo, Costa Rica. Costa Rica, type in B.M.] Panama.

204a. Spizaëtus butesi W. Sclat., Bull. B.O.C., S. Cameroon. xxxix., p. 87 (1919). Bitye, Ja River, type in B.M.] 


\section{CORRIGENDA.}

Pt. 1 p. 3 Gell. V. For Pseudogryphus read: Gymnogyps Less. (1842). " ", 3. "VI. For Serpentarius read: Sagrttarius Herman (1783): , , , 4 No. Sb. For Gyps fulvus kolbi etc., read:

Gyps fulvus coprotheres (Forst.) Naturgesch. African. Vögel, p. 35 (1798). [S. Africa.]

Pt. 2 p. 46 No. 139. For Buteo jakal, etc., read:

Buteo rufofuscus rufofuscus (Forst.) Naturgesch. African. Vögel, p. 59 (179S). [S. Africa.]

" , , 46, , 139a. For Buteo jaka! archeri read :

Buteo rufofuscus archeri.

, ,, ,72, 200c. Delete article and read :

Smaller and lacking 2 long crest feathers.

Spizaëtus nipalensis fokicnsis W. Sclat.,

Bull. B.O.C., xl., p. 37 (1919). [Fokien (breeding)

Prov., type in B.M.]

[Inserted by error in pt. 2 without ref. to publication, owing to delay in pub, of Bull. B.O.C.] 
PART I.-JULY, 1919.

A

\section{SYNOPTICAL LIST}

OF THE

ACCIPITRES

(Diurnal Birds of Prey)

\section{PAR'I I.}

(Sarcorhamphus to Accipiter)

Comprising Species and Subspecies described up to 1914, with their Characters and Distribution

BY

H. KIRKE SIVANN, F.Z.S.

LONDON :

John Wheldon \& CO., 38, Great Queen Street, KingSWAY, W.C.2. 



\section{A \\ SYNOP'TICAL, TIST}

OF THE

\section{ACCIPITRES}

(IILRNII, BIRIS OF PRES)

\section{P.IR'T I.}

Order CATHARTIDIFORMES.

Fam. I. CATHARTIDE (New World Vultures).

Nostrils perforated; head, neck and forepart of breast bare; hind toe short and weak.

\section{Gen. I. SARCORHAMPHUS Dum. (1806).}

Size large, length 38 in.: head with an erect fleshy carmele; outer toe about equal to immer.

Plumage black, with a whitish wing patch.

1. Sarcorhamphus gryphus gryphus (Limn.). Syst. Andes of Nat., i., p. 86 (1758).

Great Condor.

S. America.

Plumage brown [doubtfully distinct].

1a. Sarcorhamphus gryphus equatorialis sharpe, Eeuador.

Cat. Birds B.M., i.; p. 21 (1874).

Bromm Condor.

\section{Gen. II. GYPAGUS Vieill. (1816).}

Head with fleshy earuncle; outer toe longer than inmer.

Plumage black and cream colour; size morlerate, length $27 \mathrm{in.}$

2. Gypagus papa (Limn.), S.N., i., p. 86 (1758). S. America, King Vulture.

N. to Mexico. 
Gen. III. CATHARISTA Vieill. (1816).

Head withont caruncle; tail square.

Plumage blaek : larger : wing 17.50 ; tail 8.50 ;

tarsus 3.35 in.

3 Catharista urubu urubu* (Vieill.), Ois. d'Am.,

Sept., pl. xi. (1807).

Black Vulture.

Smaller: wing 16.30 ; tail 8 ; tarsus $3.10 \mathrm{in.}$

3a. Catharista urubu foctens (Wied), Beitr. Naturg. S. Ameriea.

Bras., iii., p. $58(1830)$.

S. Ameriean Black Vulture.

Gen. IV. CATHARTES Illiger (1811).

Tail rounded.

Plumage black : larger : length 30; wing 21.70 ;

tail $11.50 \mathrm{in}$; tarsus $2.90 \mathrm{in}$.

4. Cathartes aura aura (Linn.), S.N., i., p. 86 Tropical

(1758).

S. American Turkey Vulture.

S. America

from

Colombia to

Chile\& Brazil.

Smaller: length 27; wing 21; tail 10;

tarsus $2.35 \mathrm{in}$.

4.a. Cathartes aura septentrionalis (Wied), J.f.O.. N. Ameriea

1856, p. 119.

N. Ameriean Turkey Vulture.

(United

States) S. to

Honduras.

Median wing coverts and seeondaries very distinetly shaded with whitish ashy.

4h) Cathartes aura fallandicus (Sharpe), Ann. N.H., (4), xi., p. ]333 (1873).

Falkland Island Turkey Vulture.

Head yellow; "shafts of quills and tailfeathers brown above, white below' [doubtful form].

4c. Cathartes aura perniger (Sharpe), Cat. Bds., B.MI., i., p. 25 (1874).

Venezuelan Turkey Vulture.
N. \& Central

Cuba,

Jamaica. 
Head orange; shafts to primaries above and below white*.

4d. Cathartes aura urubitinga Pelz., Sitz. Akarl. Brazil N, to Wien, xliv., p. 7 (1861).

Yellow-necked Turkey Vulture.

Surinam, Brit. Guiana, Venezuela \& E. Mexico (?)

Gen. $V$. PSEUDOGRYPHUS Riclgw. (1874).

Head without caruncle; tail square.

Size of Sarcorhamphus; length $49 \mathrm{in}$. ; wing 30.

5. Psendogryphus californicus (Shaw \& Nodder),

Nat. Misc., ix., p. 1, pl.301 (1797).

Californian Condor.

S. California

to lower

California.

\section{ORDER ACCIPITRIFORMIFS.}

Sub-Order I. SERPENTARII.

Fam. I. SEPPENTARIIDE.

Both inner and outer toes eomnected with middle one by welldeveloped basal web.

Gen. VI. SFRPENTARIUS Curier (1798).

Head crested.

Darker.

6. Serpentarius serpentarius serpentarius (Miller), S. \& E. Africa

Var. Subj. Nat. Hist., pl. 28, (1785).

Secretary Bird.

N. to Ben

guela on $\mathrm{W}$. and Zambesi on E.

Paler.

6a. Serpentarius serpentarius gambiensis Ogilby, Senegambia P.Z.S., 1835, p. 105.

Northern Secretary Bird.

Sudan to

Shoa.

Sub-Order II. ACCIPITRES.

Fam. I. VULTURIDE (Old World Vultures).

Head and neek bare, or with short down only, no feathers ; nostrils not perforated.

* Cory ("Bds. of Ballama," p. 134, 1890) says shafts of C. aura septentrionalis are "yellowish externally" in winter plumage. I believe $U$. $\iota$ perniger and $C$. a. urubitinga to ise identical; both have the bead yellow and ranges intermingle. 
Gen. VII. AEGYPIUS Savigny (1809).

Nostrils romded.

Size large, length $42 \mathrm{in.}$; plumage blackish

brown; ruff of feathers round hind neek.

7. Egypius monachus (Linn), S.N., i., p. 122 (1766).

Cinereons Vulture

S.E. Europe,

N.E. Africa,

C. Asia to

India \&

China.

Gen. VIII. GYPS Savigny (1809).

Nostrils perpendicular, rather oral; tail with 14 teathers

Size large, length 40 in. ; plumage stone-buff ; neck ruff of white down; head with white down.

8. Gyps fulvus fulvus (Gmel.), S.N., i., p. 249 (1788).

Griffon Vulture.

S. Europe,

(ace. Britain),

N. Africa,

Arabia,

Palestine.

Phmage paler and more isabelline reddish.

Sa. Gyps fulvus fulvescens Hume, Ibis, 1869, p. 356 .

Indian Griffon.

N.W. Tndia, Himalayas. Afghanistan.

Paler than G. fulvus fulvus, especially below, and shaft stripes nearly obsolete.

Sb. Gypss fulous holbi (Dand.), Traité, ii., p. 15 S. Afriea, $(1800)$

Kolbe's Griffon.

N. to Zam-

besi and

Damaraland.

Plumage above isabelline whitish ; below light buff with broader whitish shaft stripes.

9. Gyjs, himalayensis Hume, Rough Notes, i., Turkestan, p. $14(1869)$.

Himalayan Griffon.

Himalayas,

Thilet.

Down on head yellow; phmage above blackish brown with whitish edgings; below creany buff ; crop-patch dark brown.

10. Gyps reppelli rneppelli (Brehm), Namm, 1852, N.F. Afriea, heft 3, p. 44 .

Rueppell's Tulture.

Abysinia,

N. Nigeria, Senegambia. 
Plumage above browner; below whitish.

10a. Gyps rueppelli erlangeri, Salvad., Bol. Mus. Abyssinia, Torino, xxiii., No. 576 (1908).

Frlanger's Vulture. Erythrea, Somaliland.

Head bare; ruff and upper parts dark brown with fulvous central streaks; rump white; below light brown with white streaks; croppateh brown.

11. Gyps indicus indicus (Scop.)(*), Del. Faun. et India, IndoFlor. Insubr., ii., p. 85 (1786).

Indian Long-billed Vulture.

Chinese

countries, Malay

Peninsula.

Above pale earthy brown; below whity brown; crop-patch dark brown; ruff white (Hume).

11a. Gyps indicus pallescens Hume, Stray Feathers, N.W. India. i., p. 150 (1873).

Pallid Vulture

\section{Ge12. IX. GYMNOGYPS Less. (183I).}

Tail of 12 feathers.

Size large, length 30 in.; above and eroppatch black; ruff white, rather scanty ; rump white; below chocolate brown.

12. Gymnogyps bengalensis (Gmel.), S.N., i., p. 245 India, Indo(1788).

Indian White-backed V'ulture.

Chinese

countries,

Malay

Peninsula.

Above and crop-patch dark brown; below pale brown, with yellowish-white shaft lines.

13. Gymnogyps africanus africanus (Salvad.), Nat. Stor. R. Accad. Torin., 7th May, 1865, p. 133.

Af ican White-backed Vulture.

N.E. Africa, Khartoum to Abyssinia \& Upper White Nile.

Plumage more greyish.

13a. Gymnogyps africanus schillingsi Erlanger, Orn. MLb., xi., p. 22) (1903).

German

E. Africa.

Paler.

13b. Gymnogyps africanus fuellebomi Erlanger (t.c.) Nyasaland to Angola.

* Reichenow's Gyps cinnamomeous from Alatau (Orn. MIb., 1907, pp 30-31) appears to be another subspecies [doubtful] of $G$. fulvus. 
Still paler.

13c. Gymnogyps africamus zechi Erlanger (t.c.) Togoland.

Gen. X. JORGOS Kanp (1828).

Hearl with fleshy folds and a neck-lajpet; tarsus longer than middle toe.

Above and crop-patch brown; ruff of brown feathers on hind neek; below clothed with white down, with brown laneeolate feathers on breast and abdomen.

14. Jorgos tracheliotns (Forst.) Levaillant, Reise Afr., ii., p. 362, pl. 12 (1791).

Sociable Vulture.

Above and crop-patch black; across breast a circlet of white down; below black; ruff small, black.

15. Otogyps calvus (Scop.), Del. Faun. Insubr., ii., Turkestan, p. $85(1786)$.

Pondicherry Vulture.

S. Africa.

Egypt,

Abyssinia, Upper White

Nile, cas. in

Europe.

India, Burma, Siam, Cambodia.

Gen. XI. LOPHOGYPS Bp. (IS54).

Head covered with down; no neck-lappet.

Plumage blackish brown, rump paler; ruff dark brown; crop-patch and under parts white.

16. Lophogyps occipitalis (Burch.), Trav., ii., p. 329 (IS24).

White-headed Vulture.

N.E. Africis

\&S. Africa, Sencgal on W.

Gen. XII. NEOPHRON Savigny (1808).

Forepart of chest bare.

Plumage white; primaries black; length 25

in. ; wing 19.2.

17. Neophron percnopterus percnopterus (Linn.),

S.N., i., p. 87 (1758).

Egyptian Vulture.

S. Europe, Africa S. to Mashonaland, Mediterranean Persic sub-region to N.IV. India. 
[Doubtfully distinct.]

17a. Neophron percnopterus rubripersonatus Zaruday Pessian \& Har'ms., Orn. Mb., x., p]. 52-3 (1902).

Baluchistan.

Smaller than typical form; length 21 in.; wing 15.5 .

17b. Neophron percnoplerus ginginianus (Lath.), Indian Ind. Orn. i., p. 7 (1790).

Indian White Vulture.

Peninsula, very rare in Ceylon.

Gen. XIII. NECROSYRTES Gloger (1842).

With a fur-like chest-patch.

Plumage chocolate brown; hind neck eovered with whitish down; crop-patch creamy brown, encircled with white down. Length 24 in.; wing 18.50.

18. Necrosyrtes monachws monachus (Temm.), l1. Col., i., pl. 222 (1S23).

Northern Hooded Vulture.

N.F. \& E. Africa, W. Africa.

Larger ; length 26 in.; wing 20 in.; with shorter and stonter bill.

18a. Necrosyrtes monachus pileatus (Burch.), Trav., S. Africa. ii., p. 105, (1S24).

Hooded Vulture.

\section{Fam. II. FALCONIDE.}

Crown of head always clothed with feathers, its sides either feathered or bare; outer toe not reversible.

$$
\text { Sub-Fam. I. POL YBORIN.E. }
$$

Toes connected near base by interdigital membrane; sicles of face mostly bare.

\section{Gen. XIV. POINBOPuS Vieill. (I8I6).}

Nostrils oval. Size large (22-26 in.).

Above and below blackish brown with narrow whitish bars: tail whitish with a terminal blackish band; face, neck and breast white with blackish bars.

19. Polyborus plancus (Mill.) Var. Subj. Nat. Hist., Pl. 17 (1778).

Common Caracara.

S. America, Patagonia to $20^{\circ}$ s. lat. on IV. \& Amazoll on E. side. 
Above black, mantle only with creamy buff wavy bars; upper tail-coverts white; tail bufl with 13 or 14 black bars and a broad terminal band.

20. Polyborus cheriway (Jacq.), Beitr., p. 17, tab. 4 (1.784).

Audubon's Caracara.

S. United

States,

Central

America,

Northern

S. America.

Paler insular race.

20a. Polyborus cheriuay pallidus Nelson, Pr. Biol. Soe, Wash., xii., p. $\$$ (1898).

Tres Marias Caracara.

General phmmage marked with transverse bars of brownish black and brownish white; crown, wing-coverts, terminal portion of primaries and terminal band on tail blackish hrown.

21. Polyborus lutosus Ridgw., Bull. U.S. Geol. Surv. Terr., i, p. 459 (1875).

Guadelompe Caracara.

Gen. XV. IBYCTER Vieill. (1816).

Hear generally with recurved crest.

Nostrils round. Size variable (16-25in.).

Plumage black with greenish reflections; a white band across base of tail.

22. Ibycter ater (Vieill.), Analyse, p. 22 (1816).

Yellow-throated Caracara.

Plumage black with greenish reflections, but abdomen white; face and throat deep red.

23. Ibycter americamus (Bodd.), Table Pl. Enl., p. 25 (1783).

Red-throated Caracara.

Amazon

District of

S. America.

Tropical S.

America and

Central

America, from Brazil

to Guatemala.

Plumage black with greenish reflections, but upper tail coverts, base and tip of tail and abdomen white.

24. Ibycter megalopterus (Meyen), Nov. Act. Cas., S. America, xvi., Suppl., i., p. 64, pl. 7 (1834).

Mountain Caracara.
Pacific side of Andes 
Above brownish black; upper tail-coverts, base and tip of tail and entire mnder parts white; sides irregularly marked with black.

2.5. Ibycter albigulares (Gould), P.Z.S., 1837, p.9. White-throated Caracara.

Skin of face and throat wrinkled and orange colour; Plumage black: rump, upper tailcoverts, tips of quills, a broad terminal band on tail, and vent w! hite; loreast with dropshaped white marks.

26. Ibycter carunculatus (Des Murs), Rev. et Mag. Zool., 1853. p. 154.

Carumeulated Caracara.

Patagonia.

Black; rump, upper tail-eoverts and base and trminal band on tail white : below white with band of black across lower throat.

27. Ibycter circumcinctus Scott, Auk, xxvii., I!10, p. 152.

Scott's Caracara

Above and below black; nape, onter upper tail-coverts, throat and breast with lanceolate white stripes; tail broadly tipped with white.

28. Ibycter australis (Gmel.), K..., i., p. 259 (1788). Falkland Is. Foster's Caracara.

Gen. XVI. MLLVAGO Spix. (1824).

Feathers on back of head erectile, forming 2 tufts; size small (about $16 \mathrm{in}$.).

Above brown, with pale ashy margins; head, neck, basal two-thirds of tail, and muier parts white.

29. Milvago chimachima (Vieill.), N. Diet., v., p. 259 (1816).

Yellow-headed Caracara.

Brazil and

Amazonia

to Guiana,

Colombia \&

Panama.

Above rufous brown; head and neek with black central streaks; upper tail-coverts white; tai! with broad subterminal dark bund ; below brownish ochre with dark shaft stripes.

30. Milvago chimango (Vieill.), N. Dict., V., p. 260 (1816).

Chimango Caracara

S. America from S.E.

Brazil to Tierra del Finego. 
Sub-Fam. II. ACCIPITRINE.

Outer toe conmected to middle one by an interdigital membrane; tibia and tarsus about equal in length.

Gen. XVII. POLYBOPoIDES Smith (1830).

Lores and sides of face bare.

Plumage silvery grey, lower back and rump and abdomen white, narrowly barred with black; quills and tail chiefly black, latter with a broad median band of white. Length $23.50-27$ in.

31. Polyborides radiatus (Scop.), Del. Famm, et Tlor. Madagascar. Insubr., ii., p. 85 (1786). Madagascar Gymnogene.

General plumage dark grey; breast and abdomen hroadly barred with black and white; tail black, tipped with white, with a broad band of dull white and an indistinct one nearer base.

32. Polyborides typicus Smith, S. Afr. Q. J., i., S. Africa, p. $107(1830)$.

Banded Gymmogene.

W. Africa, N.E. Africa (Abyssinia \& White Nile).

Gen. XVIII. CIPCUS Lacep. (1806).

Sides of face feathered; with distinct facial ruff; lores furnished with bristles; nostrils oval with no bony excrescence; tarsus reticulated behind; size moderate; lengtl (males) 17-22.50 in.; females $19-24.50 \mathrm{in}$.

\section{Key to Natural Groups and Species (Males).}

A. Above bluish ashy, or greyish.

a. Thighs uniform white.

Throat and chest bluish ashy; upper tailcoverts white.

33. Circus cyaneus cyaneus (Linn.), S.N., i., p. 126 Europe and (1766).

Hen Harrier. Siberia, N.E. Africa, India, China, Japan (winter). 
More brownish ashy above and below.

33a. Circus cyaneus hudsonius (Iinn.), S.N., i., N. America, p. 128 (1766).

Marsh Hawk.

Central

Ameriea \&

IV. Indies

(winter).

Actult plumage unknown.

34. Circus macroscelis A. Newton, P.Z.S., 1863, Madagascar. p. 180.

Madagasear Harrier.

Throat and chest white; npper tail-coverts white, banded with ashy grey.

35. Circus macrures (S. G. Gmel.), N. Comm. Emope; Petrop.. xv., p. 439, pls. viii., ix. (1771). Africa, Pallicl Harrier.

India, Burma, China in winter.

b. Thighs white, with rufous streaks or spots.

Throat and ehest pale bluish grey; upper tail-coverts white, tipped with deep ash colour.

36. Circus pygargus pygargus (Limn.), S.N., i., p. 89 (1758).

Montagu's Harrier.

Europe ;

Palestine, Africa, India, China in winter.

[Doubtfully distinct.]

36a. Circus pygargus abdulle Floericke, Orn. Mb., Cancasus. iv., p. 155 (1896).

e. Thighs white, barred across with orange rufous.

Throat and chest white, barred with orange tawny; upper tail-coverts white.

37. Circus cinereus Vieill., N. Dict., iv., p. 434 Tropical and (IS16).

Cinereons Harrier.

temperate

S. America, migrating to Straits of Magellan \& Falkland Is.

d. Thighs rufous, either uniform or spotted and margined with white. 
Throat and ehest rufous with white spots; upper tail-coverts ashy brown, tipped and spotted with white.

38. Circus assimilis assimitis Jard, and Selb., Ill. Orn., Ser. i., pl. 51 (1828). Spotted Harrier.

E. Australia, Tasmania, Celebes.

[Doubtful form.] Said to be smaller and (larker.

38a. Circus assimilis rogersi Math., Nov. Zool., N.W. xviii., p. 244 (1912).

Lesser Spotted Harrier.

Australia.

B. Above brown.

a. Thighs white, with rufous streaks or spots.

Throat and chest white streaked with pale rufous brown; upper tail-eoverts white, slightly spotted with pale rufous.

39. Circus approximans approximans Peale, U.S. Fiji Islands Explor. Exped.. viii., p. 64 (1848).

Fijian Harrier.

Larger.

39a. Circus approximans gouldi (Bp.), Consp., i., S. \& E.

p. $34(1850)$.

Allied Harrier.

Australia, Tasmania

Smaller.

39b. Circus approximans inexpectatus Math., Nov. Zool., xviii., p. 245 (1912).

Little Allied Harrier.

Smaller and darker than $C$. a. gouldi.

39e. Circus approximans drummondi Math. \& Iredale, Ibis, 1913, p. 419.

New Zealand Harrier.

b. Thighs rufous, the feathers margined with white.

Throat and chest brown, the feathers margined with white; abdomen rufons; upper tail-coverts orange rufous, tipped with white.

40. Circus ranivorus (Daud.), Traité, ii., p. 170 (1800).

S Afriean Marsh Harrier.
N.W. \& N. Australia.

New Zealand.

S. Africa below $10^{\circ} \mathrm{S}$. lat. 
Throat and chest creamy buff, the latter streaked with brown; upper tail-coverts white.

41. Circus ceruginosus ceruginosus (Limn.), S.N., i., p. $91(1758)$.

Marsh Harrier.

Europe, rare in Siberia, but in winter to India, China, Japan and Philippines, also Africa.

Much brighter eoloration, more black and white : (? lighter).

4la. Circus ceruginosus harterti, Zedl., J.f.O., 1914, N. Africa. p. 133.

Hartert's Harricr.

C. Above black or blackish.

a. Thighs white.

Throat and chest white, streaked with black; upper and under tail-coverts white.

42. Circus maillardi Verr. in Maill., l'Ile de la Rém., ii., p. 12 (1S63).

Maillard's Harrier.

Markings on throat and chest browner and broacter; under tail-coverts also streaked.

43. Circus wolfi Gurney, P.Z.S., 1865, p. 823. pl. New Calixliv.

IVolf's Harrier.

Reunion Is., Comoro Is. fornia, New Hebrides.

Throat and ehest white, streaked with black; upper tail-coverts white with remains of ashy brown bars.

44. Circus spilonotus Kanp, Contr. Orn., 1850, E. Siberia, p. 59 .

Eastern Marsh Harrier.

in winter to

E. China,

Indo-Burman countries, Malay Archipelago.

The same, but with rlistinct transverse spots of dusky cinereous on upper tail-coverts.

45. Circus spilothorax Salvad. and d'Alb., Ann. S.E. New Mus. Civ, Genov., vii., p. 807 (1875).

New Guinea Harrier 
Throat and chest black; upper tail-coverts barred with black.

46. Circus melanolencus (For'st.), Indisch. Zool., E. Siberia, p. 12, pl. xi. (1781).

Pied Harrier.

Mongolia, E. and S. India, Burma, Malay Pen., Borneo, Philippines (winter).

Throat and chest black; npper tail-coverts white with remains of rufous hars.

47. Circus buffoni (Gmel.), S.N., i., P. 277 (1788). Long-winged Harrier.

E. side of S. America, from Magellan Str. to Brit. Guiana and Venezinela, Trinidarl.

b. Thighs black.

Throat and chest hrownish black; upper tailcoverts white, the lower ones spotted with black.

48. Circus maurus (Temm.), Pl. Col., i., pl. 461 S. Africa. (1828).

Black Harrier.

Females (usually much different from males).

A. Above brown.

a. Thighs white.

Below white, striped with dark brown; upper C. melanotail-coverts white, barred with clark brown. leucus.

b. Thighs white, with streaks or spots of rufons or brown.

Below tawny buff, streaked with brown; C.cyaneus. ipper tail-coverts white.

Below nearly white, streaked with brown.

C. hudsonius.

Below creamy buff, with pointed spots of C. spilonotus. rufous brown; upper tail-coverts white.

Below buffy white, with rufous centres to the C.pygargus. feathers; upper tail-coverts white.

Below creamy white. with streaks of brown : $C$. macrurus upper tail-coverts white, barred with dark brown. 
c. Thighs white, halred with orange tawny.

Breast brown with white spots. rest of under cre cimerems. parts barred with orange tawny and white; 11ppere tail-coverts white, batreel with reddish.

(l. Thighs rufous.

Below dark lrown, with a white hand. marked with brown, acrosis breast : 11p]re tail-coverts ('. armaiwhite, tinged with grey and rufous.

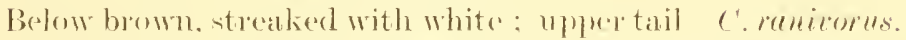
eoverts rufous, tipled with white.

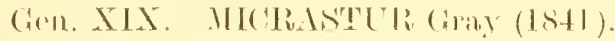

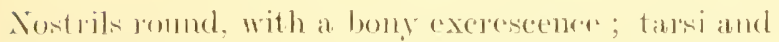

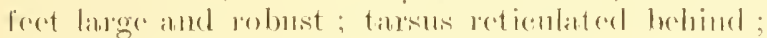
in fromt rovered with small sentellace.

Size latger, length, $\hat{j}, 20$ in., wing 10.1 ;

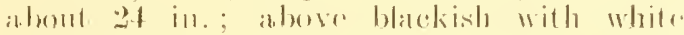
muchal eollat : tail with:3 white hambls belom white with black shate lines; jus. bolow hatered: intermediate plumager below pata achlabeons fawn, as well as sildes of face and mirchal rollarle.

mosus.

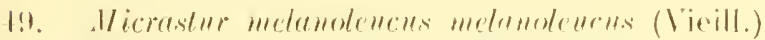

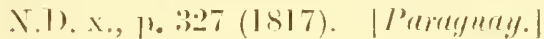
(ollarerl Harricr-Ilawk

s. Mrxin to ( olombliat. linezulelar, Barail and Patrilinaly.

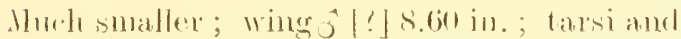
foret much smatler imel wakker white tatil

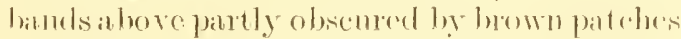

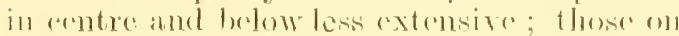

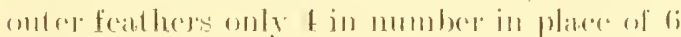
in frpical form.

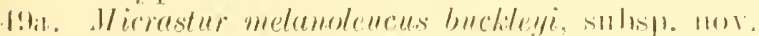

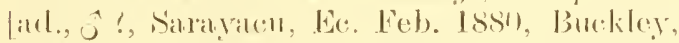
13. Mus. coll. No. $57,5.1,122$.

Size medimm, length (f) 17.5; 11 imge 9.5 :

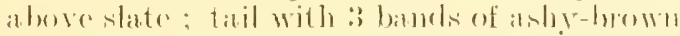
showine white below; lxelow white with bliteli shate lines: no muchial (2ollate.

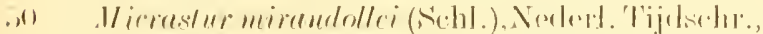
i.. 1. 1:3] ([S(3:3). | Dulch Guland.] Mirandolle: Harrier-Hawk. [ivelliklor.

lipels.

l'el'n, (miliallit, l'allitula. 
Gen. XIXA. CLIMACOCERCUS CAB. (1845.)

Feet very much smaller; tarsi more slender, with broad and regular seakes in front.

Size small, length (ô) 13 in. ; wing 6.9. Above slate or rufous (rufous phase); tail with :3 greyish white bands; below greyish white, barred with greyish black; throat white, fore-neck rufous.

5). Climacocerens ruficollis (Vicill.), N. I)iet., x., p. 322 (1817). [S. America.]

lied-necked Harrier-Hawk.

Above chocolate blown; tail blackish, with :3 narrow white bands; below thickly ban'erl with black and white; throat brown.

Jla. Climacocercus zonothorax (a)., J.f.()., 1465, 1). 406. [Porto Cabello, Tener.]

Barled Harrier-Hawk.

Above (male) ashy brown (female blackish); tail blackish with 3 irregular white bands (t in immatue) ; below whitish, breast fiucly barred with wary blackish lines: lower abdomen white.

5:). (limacocercus gilvicollix (Vieill.), N. Dict., x., 1. 3203 (1817). [Patr. ign.: c'ayemme? ]

White-thoated Harrier-Hawk.

Ibove blackish; tail with 3 irregular white bands; throat and cheeks pale grey; below dull white, chosely barred down to thighs with blizckish.

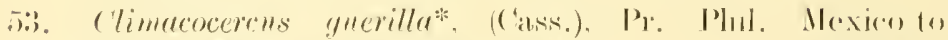

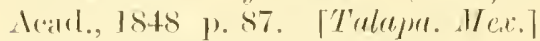
(irey-throatrel Has'ier-Hawk.

Tenczucla, Guiana,

Brazil.

Parkguay.

Colombia,

Tencezuclat.

('olombia d

Intromia to

li. P'rull aud $1020^{\circ} \mathrm{S} .1 \mathrm{at}$. in Brazil.

('olomolial. Vencemilar.

Brazil, and

Hevador.

\section{Gon. XX. GLRANOSPIZIAS Sumder. (1873).}

'Tarsus seated behind; thighs without orerhanging tult of fouthers; ridge of bill greater than half length of middle toe (without ("law) ; commissure slightly festoonert.

Size nodralde (longll $16.5-24.5$ in.).

* In revising this group the forms inguluris and imerstes appear to be untenable and are therefore onitted. 
Plumage slaty blue, with little traee of white cross bars execpt on thighs and under wing. eoverts; tail ochraceous, with 2 broad black bands.

54. Geranospizias carmlescens corrulescens (Vieill.), N. Dict., x., p. 318 (1817).

Grey Crane-Hawk.

Under parts barred with whitish.

5ta. Geranospizias ccerulescens gracilis (Temm.), Pl. Brazil, Col., i., pl. 91 (1824).

Wood Hawk.

Like G. c. ccerulescens, except that general plumage is slaty black.

5tb. Geranospizias carnlescens niger (Du Bus), Bull. Ac. Roy. Brux., xiv., p. 103 (1847).

Black Hawk.

Paragnay.

Guiana,

IV. Brazil, Peru, Bolivia Argentina.

Central

America from S. Mexico to Panama.

Gen. XXI. UROTRIORCHIS Sharpe (1874).

Tail (13 in.) longer than wing (12 in.), very strongly graduated ; size large (length 24 in.).

Above bhe grey, lighter on head and nape; upper tail-eoverts pure white ; tail very long, black above, greyish below, irregularly banded and tipped with white; below leaden grey.

55. Urotriorchis macrurus (Hartl.), J.f.O., 1855, IV. Africa, p. 353.

IV. African Grey Hawk.

Gold Coast

to Gaboon.

Gen. XXII. PARABUTEO Pidgw. (1874).

Nostrils with bony tuberele near upper margin; thighs with overhanging tuft of feathers; tarsus sealed almost right across and feathered further down than length of middle toe.

Size large (length about, $23 \mathrm{in}$. ; wing about 12-14 in.).

General colour blackish brown, variegated by lighter spotting; lesser wing-eoverts and thighs mfons; tip and base of tail and also tail-coverts white.

56. Parabuteo unicinctus unicinctus (Temm.), Pl. S. America, Col., pl.3I3 (1824).

One-banded Buzzard-Hawk northward from Chile on $\mathrm{W}$. and Buenos Ayres on E. 
General colour sooty black, tinged with chestnut on rump. (Female more brownish.)

56a. Parabuteo unicinctus harrisi (Audub.), B. Am., Central and pl. ccexcii., 1831 ; Orn. Biog., v., p. 30.

Harris's Buzzard-Hawk.

N. America from Panama to Southern U.S.

\section{Gen. XXIII. MELIERAX Gray (1840).}

Tarsus scaled in front, reticulated on outer aspect, not feathered so far down as length of middle toe.

Size large (length 21 in.; wing 14.8); general plumage bluish ash; quills black; wing-coverts, secondaries, upper tail-coverts and base of tail whitish freckled with grey; outer tail-feathers white, barred with black; belly white, narrowly barred with blackish.

57. Melierax canorus canoms (Rislach), in Thunb., Diss. Ac., iii., p. 264 (1799).

Chanting Goshawk.

S. Africa below $15^{\circ} \mathrm{S}$. lat.

Size similar ; tail-coverts white, with numerous bars of slaty grey ; tail blackish, with 4 white bands, the middle feathers unbarred; below white, minutely barred with ashy grey.

57a. Melierar canorus metabates, Heugl., Ibrs, 1861, p. 72.

Many-banded Hawk.

$[=M$. polyzonus of authors. $]$

N.E. Africa, Suclan to Mogarlor, IV. Arabia.

Much lighter form.

57b. Melierax canorus neumanni, Hart., Vög. Pal. Nubia to Fauma, ii., p. 1165 (1914).

Nenmann's Goshawk. Sudan \& Hausaland.

Pather smaller ; above darker slate; throat, chest and wings, light grey ; below white, with narrow blackish bar's ; tail black, tip and upper tail-coverts white.

57e. Melierax canorus poliopterus Cab., in Decken's Reise, iii., Vog., p. 40 (1869).

E. African Goshawk.

E. Africa, Somaliland to Kilimanjaro. 
Much darker below than M.c. metabates, which has white bars rather broader than dark bars, reverse being case in this species.

58. Melierax mechowi Cab., J.f.O., 1882, p. 229. Angola Goshawk.
Angola, Damaraland to Mashonaland, Nyasaland.

Size small (length 11.5-13.6; wing 7.1-8.3); above and throat ashy grey; rump blackish, upper tail-coverts white; quills and tail brown banded with black; below white barred with ashy grey.

59. Melierax gabar (Dand.), Traité, ii., p. 89 (1800).

Red-faced Goshawk.

S. Afriea, E. \& N.E. Afriea.

Size similar; plumage black; quills and tail banded as in $M$. gabar. Feet cinnabar red (orange in last-named). [Disputed specier.]

5:a. Melierax niger (Vieill.), Ene. Meth., iii., p. 1269 (1823).

African Black Goshawk.

S. and E

Africa.

\section{Gen. XXIV. ASTUR Lacep. (1801).}

Bill short, entting edge of upper mandible with a festoon ; nostrils oval, with no bony tubercle; toes moderate, middle one somewhat longest, outer and inner nearly equal.

\section{Key to Natural Grotps and Species (Adults).}

A. With conspicuous line of white on each side of crown, from above hinder ear-eoverts ; crown blackish; above ashy brown; below white barred with greyish brown; tail with 4 dark bands ; length, ô, 19-20.5; 9, 23-24 in.

60. Astur gentilis gentilis, Linn, S.N., i., P. 89 Europe and (1758).

Common Goshawk.

Siberia ; in winter to $\mathrm{N}$. Africa and Himalayas.

Smaller and darker race

60a. Astur gentilis arrigonii Kleinsch., Om. Mb., Sardinia. xi., pp. 152-3 (1903).

Sardinian Goshawk. 
Less brownish, purer grey

60b. Astur gentilis schvedowi Menz., Orin. Geogr. N. Asia to

Eur. Russia, p. 439 (1882).

Thibet.

Siberian Goshawk.

"White" race.

60c. Astur gentilis candidissimus Dyb., Bull. Soc. Kamtschatka Zool. France, viii., p. 353 (1883).

Kamtschatka Goshawk.

Above bluish ash, with blackish shaft stripes: crown deeper black; below closely freckled or vermiculated, instead of barred ; tail bands indistinct.*

61. Astur atricapillus (Wils.), Am. Orn., vi., pl. 52, fig. 3 (1S12).

American Goshawk

\section{N. America (except Pacific side), acc. in Brit. Isles.}

Markings of lower parts fine and delicate and so dense as to present a nearly miform appearance; tail bands obsolete.

61a. Astur atricapillus striatulus Rirlgw., Hist. N. Am. Birds, iii., 1. 240 (1874).

Western Goshawk.

W. North

America,

Sitka to

Sierra

Nevada.

Above sepia brown; head, neck and upper mantle blackish slate; nape varied with white; tail with 6 irregular darker bands; below white, thickly and broadly barred with blackish.

62. Astur hensti Schl., Mus. P.B. Revue Accipitr., Madagascar. p. 62 (1873).

Henst's Goshawk.

B. Sides of crown uniform with crown itself; no distinct red nape band; maximum length 20 in. ( $(+)$

* The young of most species of the genus Astur, both in the typical group and many succeeding ones, are brown alıove, the feathers more or less margined with ochraceous or rufous, and ochraceous or creamy white below with longitudinal markings, usually in the form of streaks on throat and large oval spots on breast and flanks, although in some species the flanks mav be barred. 'The characters given, as in other genera, are those of adult birds. 
a. Above brownish or slate; tail with about 3 darker bands; below white, barred with rufous; length, ô, 13.5-14; $q$, 16-17 in.

63. Astur tachiro tachiro (Daud.), Traité, ii., p. 90 S. E. Africa. (1800).

African Goshawk.

Below lighter; cross bands more distinet; no bars on under wing-coverts.

63a. Astur tachiro sparsimfasciatus* Reichen., Orn. MIb., iii., p. 97 (1895).

Zanzibar Goshawk.

Zanzibar Is., Brit. E.

Africa, Victoria

Nyanza.

Flanks and transverse bars more richly rufescent.

63b. Astur tachiro unduliventer (Rüpp.), Nene Wirb., N.E. Africa p. 40 , taf. 18 , fig. i. (1835).

Abyssinian Goshawk.

(Abyssinia).

Thighs rufous, without bars; under wingcoverts white.

63c. Astur tachiro macroscelides Hartl., J.f.O., W. Africa 1855 , pp. 354,360 .

West African Goshawk.

(Gold Coast

to Sierra

Leone).

b. Above slaty grey; below with breast rufous, or partly so, and rest of under parts white, barred with rufous.

64. Astur trivirgatus trivirgatus (Temm.), Pl. Col., i., pl. 303 (1824).

Indian Crested Goshawk.

Hilly parts of India and Ceylon, Malay Archipelago.

Larger.

64a. Astur trivirgatus rufitinctus McClell., P.Z.S., 1839, p. 153.

Larger Crested Goshawk.

E. Himalayas

to Assam,

İuclo-

Chinese

countries,

Formosa.

* A. tachiro nyansa Neumann, Orn. MIb., xiii., p. 138 (1902) is a synonym, cf. Sharpe, Zool. Rec., 1902, Aves, p, 45. 
e. Above brown: head bluish grey; tail with about 4 dark bars: below white, with broad streaks of brown; thighs barred with blackish brown.

65. Astur griseiceps Schl., Mns. P.B., Astures, Celebes. p. 23 (1S62).

Grey-headed Goshawk.

d. Smaller (length, ô, 10.7 in.) ; above brownish ash; sides of head and of neek rufous; tail with 6 dark bars; below white, barred with rufous.

66. Astur brutus (Poll.), Nederl. Tijdsehr., iii., Mayotte Is. p. $80(1866)$.

Least Goshawk.

(Comoro

Group).

e. Above blackish slate or slate ; tail with 2 more or less regnlar white bands; below pale vinous to rufous, with indieations of white bars; length 15-in. (adult).

67. Astur toussenellii toussenellii (Verr.), Rev. et Mag., 1854, p. 538.

Toussenell's Goshawk.

IV. Africa

(Gaboon).

Smaller; length 13-in. (人) ; thighs ehestnut.

67a. Astur tonssenellii lopezi* Alex., Bull. B.O.C.; Cameroon \& xiii., p. 49 (1903).

Fernando Po.

Fernando Po Goshawk.

Smaller; length 11 in. (ô); below banded with white and ehestnut.

67b. Astur toussenellii castanilius (Bp.), Rer. et W. Africa Mag. de Zool., 1853, p. 578.

Chestmut-sided Goshawk.

(Gold Coast

to Gaboon?),

Cameroon.

Withont white bars bolow ; thighs white.

68. Astur trinotatus (Bp.), Consp., i., p. 33 (1850). N. Celebes. N. Celebean Goshawk.

Paler below, with more white on abdomen.

68a. Astur trinotatus hresitandus (Hart.), Nov. S. Celebes. Zool., iii., p. 162 (1S96).

S. Celebean Goshawk.

* Doubtfully distinct from A.t. castanilius if it has the rufous thighs of the latter. The amount of white barring most certainly varies with age. 
f. Above deep slate grey; tail with 8 or 9 dark bars; below wholly ehestmut with a few whitish eross bars.

69. Astur henicogrammus Gray, P.Z.S., 1S60, Noluecas p. 343.

Gray's Goshawk.

(Hahmahéra, Morotai).

g. Above slate grey; bars on tail nearly obsolete ; below einnamon rufous, withont white bars; length 우 15.8 ; ô $12.5 \mathrm{in}$.

70. Astur iogaster (Mull. et Schl.), Naturl. Gesch., Noluceas p. $110(1839-44)$.

Rufous-bellied Goshawk. (Ceram and Amboina).

Slightly smaller; below more vinous red.

71. Astur etorques elorques (Salvad.), Ann. Mus. Civ. Genov., vii., P. 901 (1875).

New Guinea Goshawk.

Guinea, Salawati and Jobi Is., Bismarck Arehipelago.

Whole under side deep rufous eimmanon.

71a. Astur etorques rufoschistaceus Rothseh. and Hart., Nov., Zool., ix., p. 590 (1902).

Ysabel Is. Gosliawk.

Ysabel Is., Solomon Arehipelago.

Simatler and darker.

71b. Astur etorques rubiane Rothseh. and Hart., Solomon ls. Nov. Zool., xii., pp. 250-1 (1905).

Solomon Island Goshawk.

(Rubiana,

Piendlova, Gizo).

Lighter above.

71e. Astur etorques bougainvillei Poth. and Hart., N. Solomon Nov. Zool., xii., pp. 250-L (1905).

Bougainville Is. Goshawk.

Is. (Shortland Group \& Bougainville Is.).

Smaller (length of ad. 12.2 in.) and more delicate grey above.

71d. Astur etorques mismiensis (Salvad.), An. Mus. Civ. Genov., vii., p. 904 (1875). Misori Goshawk.

Is. of Misori, N.W. New Guinea, Jobi Is. (?) 
Under wing and tail-eoverts whitish; thighs reddish white.

7le. Astur etorques pulchellus Ramsay, Jnl. Linn. Solomon Is. Soc., xvi., p. 131 (1881).

Ramsay's Goshawk.

(Cape Pitt,

Florida Is.,

Guadaleanar, Ysabel Is.)

h. Above paler ashy grey; crown bluish; tail uniform; below paler salmon eolour, with remains of white bars on breast, more numerous on abdomen.

72. Astur sylvestris (Wall.), P.Z.S., 1863, pp. 484, Lesser Sunda 487.

Flores Goshawk.

Is. (Flores).

i. Above bhish grey ; tail with 5 or 6 blackish bars; below salmon rufous, with white cross bars.

73. Astur badius badius (Gmel.), S.N., i., p. 280 (17SS).

Ceylonese Shikra.

Ceylon.

Travancore.

Larger and lighter grey.

73a. Astur badius dussumieri Temm., Pl. Col., livr. Whole of 52. pl. 308 (1824)

Shikra

Indian

Peninsula.

Above paler bluish ; below with broader and brighter vinous bands.

73b. Astur badius poliopsis (Hume), Stray Burma, Feathers, ii., 1874, p. 325. Assam, Hunie's Shikra.

Cachar,

Tenasserim,

Siam, and

Gamboja to

to Cochin

China,

Formosa.

Tail slightly longer and more barred.

73e. Astur badius cenchroides Severtz, Turkist. Central Asia Jevotn., p. 63 (1S73).

Severtzow's Shikra.

(Turkestan),

Baluchistan,

E. Persia and Punjab, sind (winter). 
Mantle blackish slate; below paler salmon colour, under wing-coverts distinctly barred.

73d Astur badius brevipes Severtz., Bull. Soe. Imp. Nat., Moscou, xxxiii., p. 234, tab. i.-iii. (1850). Levant Shikra.

Central

Russia,

Dalmatia, Grecce,

Turkey, Asia

Minor, Persia, Syria, Egypt.

Above clear bluish ashy, under wing-coverts buffy white, with faint dusky cross bars.

73e. Astur badius sphenurus (Rüpp.), Neue Wirb., p. 42 (1835).

Riippell's Goshawk.

N.E. Africa, Sudan to Senegambia, Sierra Leone, Nigeria.

Below with numerous distinct narrow bars of pale rufous; under wing-coverts barred like breast.

73f. Astur badius polyzonides (Smith), III. Zool. S. Afr., pl. xi. (1838).

Little Barred Goshawk.

Tail with only one indistinct subterminal bar ; under wing-eoverts white.

74. Astur butleri Gurney, Bull. B.O.C., vii., p. xxvii. (1898).

Butler's Goshawk.

S. Africa, N. to Nyasaland.

Tail with 5 bars; body below, pale buffy vinous without bars.

75. Astur soloensis soloensis (Lath.), Gen. Hist., i., p. 209 (1821).

Horsfield's Goshawk.

Car Nicobar

Is., Bay of

Bengal.

Tail bars obsolete above.

75a. Astur soloensis cuculoides Temm., Pl. Col., i., pl. 110,129 (1823).

Chinese Goshawk.

China, S.in winter to New Guinea.

N. China, S. in winter to Malay Arehipelago.

k. Head, neek and upper part of mantle light greyish white; rest of upper parts slate grey ; tail uniform; below vinous rusty red.

76. Astur pallidiceps (Salvad.), Orn. d. Papuasia, Bouru. etc., i., p. 64 (187!).

White-headed Goshawk. 
1. Above as last, but tail with blaekish bars; below entirely white.

77. Astur poliocephalus (Gray), P.Z.S., 1858, PP. $170,189$.

Grey-headed Goshawk.

New Guinea, Salawati, Mysol, Waigiou and A111 [s.

m. Above uniform slate eolour; tail with 7 darker bars; below entirely white.

78. Astur francescii francescii (Smith), Afr. Q. Jnl., Madagasear. ii.. p. 280 (1834).

Franees's Gosliawk.

Smaller and darker above.

78a. Astur francescii pusillus Gurney, Ibis, 1875, Joanna or 1. 258.

Joanna Island Goshawk.

Anjuan Is.

(Comoro

Group)

n. Above brownish ash eolour; below white barred with dull ashy.

79 Astur clarus clarus (Lath.), Ind. Orn. Suppl., p. xiii. (1801).

Grey Goshawk.

79a. Astur clarus cooktowni (Math.), Nov. Zool., xviii., p. 245 (1912).

Northem Grey Goshawk.

o. Above and below pure white.

80. Astur novcehollandice (Gmel.), S.N., i., p. 264 (1788).

White Goshawk.

E. side of

Australia.

N. Queensland.

Smaller; wing o 7.8 against $10.4 \mathrm{in.}$

80a. Astur novchollandice leucosomus Sharpe, Cat. Bds. B.M., i., p. 119 (1874).

Lesser White Goshawk.

p. Above slate black; below white streakcd and barred with black.

81. Astur endiabolus Roth. \& Hart., Bull. B.O.C., Mountains of xxxv., p. 8 (1914).

Black-and-White Goshawk.

Brit. New

Guinea.

q. Above blackish slate; below white.

82. Astur haplochrous (Selat.), Ibis, 1859, p. 275, New pl. viii.

Black-throated Goshawk.

Caledonia. 
r. Above black, or blaekish slate; tail unbanded : bekow white, with or without slight greyish shading or vermiculations on sides of chest. Length, o, about 18 in., $\hat{0}$, abont 14 in.

83. Astur albigularis albigularis (Gray), Ann. N.H., (4) v., p. 327 (1870).

White-throated Goshawk.

Solomon

Islands

(S. Christoval Ugi, Ginadal-

cantar.)

Larger ; cheeks white; below with some black shaft streaks and cross bars [doulbtful form]. 83a. Astur albigularis meyerianus Sharpe, Inl. Linn. Soc., xiii., 1. 458, pl. xxii. (1877).

Mever's Coshawk.

Tail with 4 whitish bands above; cheeks and ear-coverts black.

84. Astur jardinei* Gurney, Ibis, 1887, p. 96, pl. iii.

Jardine's Goshawk.

Above dark lead grey ; below pale grey.

85. Astur poliogaster ('Temm.), Pl. ('ol., i., pll. 264 (1824).

Grey-bellied Goshawk.

Jobi Is. N.W.

New Guinea,

Ceram-Launt.

Brit. Guiana.

Brazil

(Ypanama),

Paraguay

C. With a well defined rufous neck band.

a. Above brown; crown black, erested; tail with 4 black bands; below, ehest rufous, rest of under parts white barred with black.

86. Astur pectoralis Bp., Rev. et Mag. de Zool., 1850 , p. 490.

Red-collared Goshawk.

Brazil,

Guiana,

Ecuador.

b. Above brownish slate; inner webs of tailfeathers obscurely barred; below, breast mufous brown barred with slate, rest paler barred with white.

87. Astur natalis Lister, P.Z.S., 1888, 1. 523. Christmas Island Goshawk.

Christmas

Is.

* If the later ascertained locality of this form, British Guiana, is corrert it must be a perfectly valid species, and can have little direct relationship with $A$, a. alligularis.

Dr. Hartert, who examined the description of Oustalet's Astur sharpei (Bull. Soc. Philom. (6), xi., p. 25, 1875) with me, thinks it is merely an example of $A$, albigularis albigularis, and I have therefore omitted it. 
c. Above light bluish grey; tail not visibly barred ; throat white; below pale vinous red, length, ô, $13.5 ;$ ㅇ, $16.5 \mathrm{in}$.

88. Astur rufitorques Peale, U.S. Explor. Exped.; Fiji Islands. p. 68 , pl. 19 (1848).

Fijian Goshawk.

Larger; above darker, except head; below with some white bars; throat bluish grey. 89. Astur griseigularis griseigularis Gray, P.Z.S., $1850, \mathrm{p} .343$.

Grey-throated Goshawk.

89a. Astur griseigularis buruensis, Streseman, Nov. Zool., xxi., p. 381 (1914).

Smaller; above as A. rufitorques; below pale vinous red; belly white.

90. Astur albiventris Salvad., Ann. Mus. Civ. Genov., vii., p. 982 (1875).

White-bellied Goshawk.

Above lighter.

9I. Astur polionotus Salvad., Mem. Accad., Torino, xl., p. 147 (1889).

Tenimber Is. Goshawk.

d. Above black; tail barred on imner webs only ; below vinous chestnut; throat black.

92. Astur melanochlamys melanochlamys (Salvad.), Ann. Mus. Civ. Genov., vii., p. 905 (1875). Black-backed Goshawk.

Above more slaty black; below paler.

92a. Astur melanochlamys schistacinus Rothsch and Hart., Nov. Zool., xx., p. 482 (1913). IIt. Goliath Goshawk.

e. Above greyish brown; tail with numerous darker bars; below white, barred with pale rufous; thighs and under wing and tailcoverts white.

93. Astur torquatus torquatus (Temm.), Pl. Col., i., Timor. pl. 43 (1823).

Collared Goshawk.

93a. Astur torquatus sumbaensis (A. B. Meyer), Lesser Sunda Abhandl. Ber. Mus., Dresd., 1892-3, p. 3. Sumba Goshawk.
Molueca Is. (Halmahéra, Batchian, etc.), Obi. Is.

Bouru,

S. Moluceas.

Kè or Kiei Is., Moluccas.

Timor

Laut.

N.W. New

Guinea.

Iount

Goliath,

Dutch New

Guinea.

Is. (Sumba). 
f. Above similar to last; below dull rufous, narrowly barred with white and ashy ; under wing-coverts chll rufous barred with fulvous. Size larger, $9,20 \mathrm{in}$.

94. Asturfasciatus fasciatus Vig. \& Horsf., Tr. Linn. Soc., xv., p. 181 (1827).

Australian Goshawk.

E. Australia,

S. to Tas-

mania,

Norfolk Is.

Smaller : "wing $236 \mathrm{~mm}$."

94a. Astur fasciatus didimus (Math.), Austral N.W.

Avian Rec., i., p. 33 (1912). Australia,

Northern Goshawk.

Northern

Territory.

Below paler ; under wing-coverts barred with vinous grey.

94b. Astur fasciatus cruentus Gould, P.Z.S., 1842, W. Australia. p. 113 (1843).

West Australian Goshawk.

94c. Astur fasciatus polycriptus Rothseh. and Hart, Nov. Zool., xxii., p. 53 (1915).

New Guinea, New Britain, New Ireland, D'Entrecasteaux Group, Wraigion Is.

94d. Astur fasciatus insularis. F. Sarasin. Noræ Caleclonia Zool. Aves, p. 8 (1913).

New

Caleclonia,

New

Hebrides,

Loyalty Is.

Below rich vinous salmon colour, with remains of white cross-bars.

95. Astur vallacii Sharpe, Cat. Bdls. B.MI., i., Lesser Sunda p. 128, pl. $5(1874)$.

Wallace's Goshawk.

Is. (Lombok), S.IV. Islands, Moluccas.

Gen. XXV. NISOIDES Pollen (1866).

Hinder aspect of tarsus scaled ; commissure of bill perfectly straight.

Above slaty black; nape and base of scapulars mottled with white and upper tail-coverts tipped with same; tail with about 8 darker 
bands; below white barred with rufous brown; throat streaked with black; length, $\hat{\jmath}, 11.5$, wing 6 in.

96. Nisoides moreli Pollen, Bull. Soc. Sc. Réun., IV. Coast of 1866, p. 62.

Morell's Goshawk.

Mardagasear.

Gen. XXVI. ACCIPITER Briss. (1760).

Bill with distinct festoon to cutting margin of upper mandible; nostrils oval ; tarsus long, slender and smooth; toes long and slender, particularly the middle one, which is more than twice ridge of bill (withont cere). Maximum size $\hat{\jmath}, 15.8$; $q$, 18 in. Minimum ô, 8.8 ; , $10.5 \mathrm{in}$.

Key to the Naturai, Groups and Species (Adults).

A. Thighs banded; no collar round neck.

a. Above bluish slate; nape more or less mottled with white; tail with about 4 darker bands; below white, breast barred with rufous or brown ; flanks rufous.

97. Accipiter nisus nisus (Linn.), S.N., i., p. 92 (1758).

Common Sparrow-Hawk.

Enrope and N. Asia, in winter to Algeria, N.E. Africa, India, China.

Smaller, darker above, more closely and thickly barred below.

97a. Accipiter nisus wolterstorffi Kleinschm., Orn. Sardinia. Mb., ix., p. 168 (1901).

Sardinian Sparrow-Hawk.

Above bluer.

97b. Accipiter nisus punicus Erlanger, Orn. Mb., Tunis. v., p. 187 (1897).

Tumisian Sparrow-Hawk.

97c. Astur nisus nisisimilis Tickell, Jul. As. Soc. India, Beng. ii., p. 571 (1833).

Indian Sparrow-Hawk

Kashmir, Assam, Burma, Afghanistan, Tnrkestan. 
Above lighter and greyer, with dark shaft stripes; dark tail bands nearly obsolete; below barred with greyish.

97d. Accipiter nisus pallens Stejn., Pr. U.S. Nat. Kamtsehatka, Mus., xvi., p. 625 (1893).

Kantschatkan Sparrow-Hawk. Japan.

Insular race. [with light and dark phases.]

97e. Accipiter nisus teneriffe Laubmann, Verhandl. Teneriffe. Orn. Ges., xi., p. I6it (1912).

Teneriffo Sparrow Hawk.

Blackish slaty above, darkest on head and nape; bars on tail broad and pronomneed; below with bars broad and deeided.

97f. Accipiter nisus melanoschistus Hume, Ibis, Himalayas. I869, р. 356.

Himalayan Sparrow-Hawk.

97g. Accipiter nisus ladygini* Bianchi, Ann. Mns. F. Thibet. St. Petersb., viii., p. 11 (1903).

Above blackish brown; below white, barred with greyish black.

98. Accipiter granti Sharpe, Ann. \& Mag. N.H. (6), Mladeira. v., p. $483(1890)$.

Madeiran Sparrow-Hawk.

Above slaty blue; below white, barred with pale rufous; the flanks barred like breast.

99. Accipiter fuscus fuscus (Gmel.), S.N., i., p. 280 (1788).

Sharp-shinned Hawk.

Paler and more eimmamomeous below ; thighs with eimamon rufous predominating.

99a. Accipt er fuscus rufilatus (Ridgw.), Pr. U.S. West U.S.. W. Mus., xi., p. 92 (1888).

Western Sharp-shimned Hawk.

N. Ameriea, in winter S. to Guatemala. to RoekvMits., N. to Kodiak, S. to Cent. Ameriea.

Smaller and more slendor; ehecks rufons; below nearly white, especially the thighs.

99b. Accipiter fuscus fringilloides † (Vig.), Zool. Jnl., Cuba, iii., p. 434 (1828) [ex Cuba]. Cuban Sparrow-Hawk.

Haiti (?).

* Judging from description this form and Hume's melanoschistus aro very near one an other. if not the same

$t$ If the Cuban and Haitian forms are the same, they should be called A. fuscus strialus (Vieill.) as being the older name. 
Below rufous, the feathers spotted on both webs or barred with white; upper breast more or less uniform rufous.

100. Accipiter cooperi cooperi (Bp.), Am. Orn., i., N. America pl. 10, f. 1 (1828).

Cooper's Hiwk.

(Middle and Southern U.S.).

Female with markings of lower parts denser and rather deeper in colour; more rufous on thighs. Male scarcely differs from typical form.

100a.Accipiter cooperi mexicanus Swains., Faun. Bor. Am., ii., p. 45, footnote (1831) [ex Mexico].

Mexican Sparrow-Hawk.

Sides of neck, a band running to hind neck, and upper part of breast greyish ash.

100b.Accipiter cooperi gundlachi (Lawr.), Ann. Lyc. Cuba.

N.Y., vii., p. 252 (1862).

Gundlach's Sparrow-Hawk.

Above slaty grey; below white, throat unspotted, rest minutely banded or vermiculated with greyish brown.

101. Accipiter superciliosus (Linn.), S.N., i., p. 128 (1766).

[=A. tinus, suct. plur. $]$

Eyebrowed Sparrow-Hawk.

b. Above slaty black; upper tail-coverts tipped with white; tail with 2 faint paler bands, and 2 large spots of white on inner webs; below white, sides bright chestnut, below narrowly barred with rufous.

102. Accipiter minullus minullus (Daud.), Traité, ii., p 88 (1800).

Little Sparrow-Hawk.

S. Africa, to to Mozambique on $\mathbf{E}$. and Angola on $W$.

Sides paler; bars darker and broader.

102a.Accipiter minullus intermedius Erlang., J. Orn., Abyssinia 1p. 171-6, 1904. (S. Shoa).

102b.Accipiter minullus hilgerti Erlang., J. Orn., Arusi, Galla pp. 171-6, 1904.

Land, N.E. Africa. 
102c.Accipiter minullus tropicalis (Reieh.), Jr. f. O., E. Africa. p. 139, 1898.

Upper tail-coverts conspicuously white; barrings below blackish brown with very little rufous.

102d.Accipiter minullus erythropus (Hartl.), J.f.O., W. Africa, 1855, p. 354 .

Red-legged Sparrow-Hawk.

Gold Coast to

Cameroons.

c. Above dark ashy grey ; tail, with 4 darker bars, alternated with paler bands, in eentre of each of whieh is a white spot; below white with narrow grey bands.

103. Accipiter oxampensis Gurney, Ibis, 1875, p. Ovampo 367 , pl. vi.

Gurney's Sparrow-Hawk.

Land, S.W.

Africa, to

Zambesi

Country,

Nyasaland, S.

Abyssinia,

Gambaga

(Gold Coast).

d. Above blackish brown; tail miform above, with paler bands beneath; below white, thiekly barred with greyish black.

104. Accipiter madagascariensis Verr., S. Afr. Q. Madagascar. Jnl., ii., p. 282 (1834).

Madagascar Sparrow-Hawk.

B. Thighs nearly nniform brown, with slight remains of white cross bars: an ill-defined white collar on hind neek.

a. Above sooty brown ; tail with 5 darker bands ; below white, broadly barred with rufous brown.

105. Accipiter collaris (Kaup), MIS. in Mus. Brit. Colombia. undé ; Sel., Ibis, 1860, p. 148, pl. 6. Semi-collared Sparrow-Hawk.

C. Thighs barred; red collar on hind neck.

a. Above bluish ash ; tail almost uniform above, but with numerous darker bars below on inner webs: below broadly barred with vinous red and greyish white.

106. Accipiter cirrocephalus (Vieill.), N. Dict., x., p. 329 (1817).

Collared sparrow-Hawk. 
Darker above.

106a.Accipiter cirrocephalus broomei (Nath.), Nov. Zool., xviii., p. 247 (1912).

Broome's Sparrow-Hawk.

W. Australia, Northern Territory.

Above clearer bluish slate; below brighter rufescent with less distinct whitish bars; thighs with bare indications of bars.

106b.Accipiter cirrocephalus papuanus Rothsch. \& Hart., Nov. Zool., xx., p. 482 (1913). Papuan Sparrow-Hawk.

D. Thighs uniform ashy grey ; red collar on hind neck.

a. Above blackish slate; red collar extending to upper interscapulary region; tail with 10 or 11 darker bands, obsolete on outermost feathers; below pale ashy grey; sides of neck chestnut.

107. Accipiter rubricollis Wall., P.Z.S., 1863, pp. 19, 21, pl.iv.

Red-collared Sparrow-Hawk.

Moluccas (Morotai, Bouru).

Above "dark blue slaty grey" ; rufous collar round hind neck.

108. Accipiter brachyurus (Ramsay), Pr. Limn. Soc. N.S.W., iv., p. 465 (1879)

b. Bars on tail nearly obsolete; below uniform clear vinous, paler on thighs; lower abdomen white.

109. Accipiter erythrauchen erythrauchen Gray, P.Z.S.. 1860, p. 344.

Grey-thoated Sparrow-Hawk.

S.E. New Guinea.

Moluceas (Halmahéra Batchian, Obi Is.)

109a. Accipiter erythrauchen ceramensis, Schl., Mus. Ceram. P.B. Astures, p. 39 (1862)

E. Thighs greyish white; no nuchal collar.

a. Above bluish grey ; sides of face and neck very pale; below clear vinous red; tail blackish slate above, with 4 or 5 clark bars beneath.

110. Accipiter rhodogaster (Schl.), Mus. P.B. Celebes Astures, 1. 32 (1862).

Red-bellied Sparrow-Hawk. 
Above darker slate grey ; sides of face and neck vinous like under parts.

110a.Accipiter rhorlogaster sulaensis (Sch1.)., Tog. Sula Istands.

Ned. Ind. Valke, p). 26, 64, pl. 16, f. 3, 4 (1866).

Sula Is. Sparrow-Hawk.

F. Thighs rufous or ochraceous ; no nuchal collar.

a. Aloove slaty grey; tail brown with about 5 ashy brown bar's; eheeks and nuder surface white, with a few dusky shaft lines and bars on breast and flanks; thighs chestunt.

111. Accipiter erythrocnemis Gray, List Accipitr. B.M., p. 70 (1S4S).

Grey-backed sparrow-Hawk.

S. America,

Brazil to

Bolivia.

Above darker and browner; head blackish; thighs pale ochre.

112. Accipiter chionogaster (Kaup), P.Z.S., 1851, Central p. 41.

White-bellied Sparrow-Hawk.

Ameriea.

(Guatemala,

Nicaragua)

Above plumbeous ; thighs cimmamon rufous.*

113. Accipiter salvini (Ridgw.), Bull. U.S. Geol. Tenezuela. Surv., ii., p. 121 (1876).

Salvin's Sparrow-Hawk.

b. Above deep slaty grey, including sides of face; below chestmut.

114. Accipiter ventralis ventratis Sclat., P.Z.S., 1866, S. Ameriea, 1). 303 .

Chestmut-bellied Sparrow-Hawk.

Venezuela to

Colombia.

Above and below plumbeous ; abdomen mixed with ferruginous rufous.

11 ta. Accipiter ventralis nigriplumbeous Lawr., Ann. Lye. N.I., ix., p. 270 (1869).

Plumbeous Sparrow-Hawk.

c. Above deep slate; nape mottled with white; side of face and uncler surface tawny rufous.

11.5. Accipiter rufiventris Smith, S. Afr. Q. Jnl., i., S. Africa, 1). $231(1830)$.

African Sparrow-Hawk.

115a. Accipiter rufiventris perspicillaris Rïpp., Nene Abyssinia. Wirb. Vog., p. 41 (1836).

Abyssinian Sparrow-Hawk.

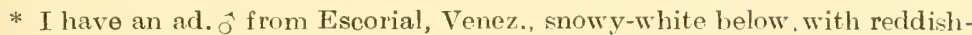
white thighs lightly barred with dusky, which seems to constitute a new form. 
d. Above slaty black, lower upper tail-coverts white ; tail with 2 bars of white on inner webs ; below ehestnut.

116. Accipiter sharpei Reieh., Vog. Afrikas, i., p. 564, pl. 2 (1901).

Sharpe's Sparrow-Hawk.

G. Thighs greyish, with traces of bars; no nuchal collar.

a. Like A. sharpei above, but no white spots on centre tail feathers; below, rufous colour paler on sides.

117. Accipiter hartlaubi (Verr.), in Hartl., Orn. W. Afr., p. 15 (1857).

Hartlaub's Sparrow-Hawk.

b. With 2 white spots on eentre tail feathers; breast faintly barred with grey; sides pale vinous.

118. Accipiter batesi Sharpe, Bull. B.O.C., xiii., Cameroons. p. 50 (1902).

Bates's Sparrow-Hawk.

H. Thighs very pale rufous or ashy to chestmut; no nuchal eollar.

a. Above blackish slate; nape mottled with white; sides of neck washed with rufous; tail with 3 blackish bars; below chestnut, paler on thighs and more or less barred below breast. Wing, ô, 6.6 ; 오 7.4 .

119. Accipiter virgatus virgatus (Temm.), Pl. Col., i., pl 109 (1S23).

Java Sparrow-Hawk.

119a. Accipiter virgatus besra Jerd., Madras Jnl. Lit. Sci., x., P. 84 (1839).

Besia Sparrow-Hawk.

Larger ; wing, ô, 6.5-7.1; q, 8.35; below with markings mueh browner.

119b.Accipiter virgatus affinis (Hodgs.), in Gray's Zool. Mise., p. 81 (1844).

Larger Besra Sparrow-Hawk.
W. Africa,

Cameroon to

Benguela.

IV. Africa

(Senegambia

to Togoland).

Greater

Sunda Is.,

Java,

N. Borneo,

Sarawak.

S. India, Ceylon.

Himalayas, Andemans, Siam, Formosa, Hainan. 
Below nearly miform light red in ad. 7 ; the ad. $\hat{j}$ like typieal race. Wing, $q, 6.9-7.3: \hat{j}$, (i-6.9 in.

119c.Accipiter virgatus confusus, Hart., Nov. Zool., Philippine xvii.. p. $209(1910)$.

$\Gamma=$ Accipiter manillensis (Meyen)?.

Islands.

Philippine S'parrow-Hawl.

Thighs and under tail-coverts miform chestmut; wing $5.95 \mathrm{in}$.

119a.Accipiter virgatus rufotibialis Sharpe, Ibis, N.W. Borneo 1857, p. 437.

Whitehead's Sparrow-Hawk.

(Mt. Kina

Balu),

Sarawak

(Mt. Dulit).

b. Female barred below, up to throat, with rufous or brown like A. nisus nisus. Wring av., $\hat{0}, 6.45 ;$;, 7.45 .

120.Accipiter gularis (Temm. \& Schl.), Famn. Jap. Aves, p. 5, pl. 2 (1850).

Japanese Sparrow-Hawk.

Japan,

N. China,

Formosa,

Malay

Archipelago,

Philippine Is.

c. Tail with 4 darker bars; below pale fawn rufous, the breast mottled with white spots and half bars. Wing, j, 8.5. ; ㅇ, 10.5.

121. Accipiter guttalus (Vieill.), N. Dict., x., p. 327 (1817).

White-throated Sparrow-Hawk.

d. Tail with 5 black bands; head black; sides of face and moler surface slaty blue, with blackish shaft stripes; thighs and under wingcoverts rufous.

122. Accipiter pileatus (Temm.), Pl. Col., i., pl. $205(1824)$.

Black-capped Sparrow-Hawk.

S. Ameriea

(Paraguay

and Bolivia).

S. America

(Brazil,

Paraguay).

c. Under wing-coverts white, rufous along earpal bend; thighs rufous: tail with 4 dark bars.

123. Accipiter bicolor (Vieill.), N. Dict., x., p. 325 (1817).

Four-banded Sparrow-Hawk.

S. Mexico to

Colombia,

Eeuador and

Guiana. 
f. Below ashy grey, with large white spots and bars, margined with brownish ; breast shaded with rufous; thighs rufous; under wingcoverts mufous mottled with brown.

124. Accipiter chilensis Phil. \& Landb., Arch. f. Chile to Str. Naturg., 1864, p. 43.

Chilian Sparrow-Hawk. of Magellan, Patagonia.

I. Thighs black; no nuchal collar.

a. Above black; tail brown with 5 blackish bands; below black, most of feathers with eoncealed white bases or spots.

125. Accipiter melanolencus Smith, S. Afr. Q. Jnl., S. Africa, i., p. $229(1830)$.

Black-and-White Sparrow-Hawk.

W. Africa

(Cameroon

Gold Coast,

Gaboon,

Niger), Cape

Verde Is.,

Abyssinia,

Ugancla. 


PAR'T II.-NOL, 7, 1919.

A

\title{
SYNOP'TTCAL LIST
}

()F THE

\section{ACCIPITRES}

(Diurnal Birds of Prey)

\author{
P'AR'T II. \\ (ERYthrotriorchis to LopHOAETUS) \\ Comprising described Species and Subspecies, with their \\ Characters and Distribution
}

BY

H. KIRKE SIVANN, F.Z.S.

\section{LONDON :}

John Wheldon \& CO., 38, Great Queen Street, Kingsivay, W.C.2. 



\section{1 \\ N'YNOPTICAI, IIST' \\ OF THE \\ ACCTPITREN \\ (I)LRNAL BHRIN OF PRES) \\ PAR'T II.}

Sub-Fam. III. BC"THNIN.J.

bill moderate, bending from hase, with at slighl projection on cut ting elge of upper mandible. Onter tor commected to mirlelle toe by an interdigital membrane; 1ibia much longer than tarsus, exereding it by more than the length of hind claw.

Gen. XXVII. ERTTHROThIOLCHIS sharpe (1875).

lling about equal to tail, the latter moderately graduaterl; ridge of hill (withome cere) lasi than half length of midello toc (withont ( law).

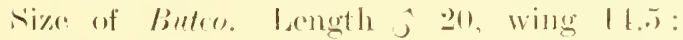
F. Wing I6 in.; plomage aloure and below bight rufous, with black conteres; tail ash,

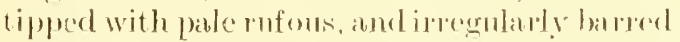
with dark brown: moler surfare of tail and tips of primaries whitish.

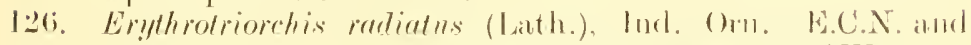

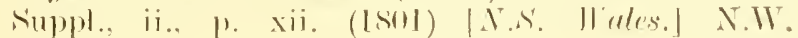

Red Buzzard. Australial.

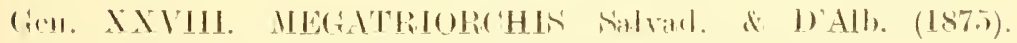

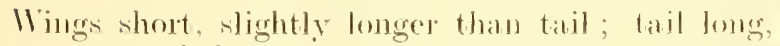
rounded; inner toe shorter than onter. 
Larger ; length 26.7 .5 , wing 14 in. : plumage above brownish black, with rufeseent margins; below white, spotted longitudinally with brown: wings and tail above banded alternately with brownish-black and grerishbrowis.

127. Megatriorchis dorice Sabrad. \& D'Alb., Ann. Mus. Cir. Genor. vii., p. 8.5 (1875). [Yule Guinea. [slam?.]

Dorias Buzzard-Hawk.

Gen. XXIX. HEIERospIZLAS Shape (1st4).

Nostrils round, with large tubereular process: wings reaching up to or beyond tail; tail about efpual to twice tarsus.

Nize of Bulco: length 0.24 , wing 18..), j.201, wing l6.5in.; head and shoulder's rufous; mantle and scapmlass pale slate gerey with rufous margins; rump and tail pusplish black, tail with a merlian white lare and white tips:

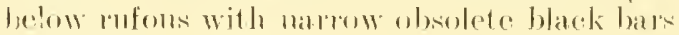
(i) breast

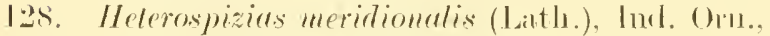
1., 1. .36 (1790). [('ulyeume.]

lind-winged Hawk.

S. Americar (C'olombial to S.E. Brazil, Paraghaýand Irgentinal).

\section{Gerl. XXX. (AERANOAETLS Kam) (ISH).}

Size much larger than Buteo; tail proportionately whorter, and wings proportionately longer.

lengthô2 28,931 , wing 23.7 , tail 11.5 in ; slatyhack, with the shombler erere, linely latred with lolackish : abdomona and moles wime amd

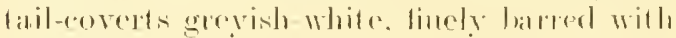
biackish.

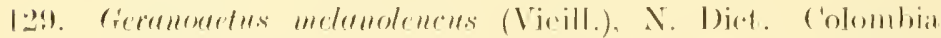

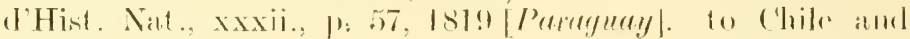
('hilian Eingle.

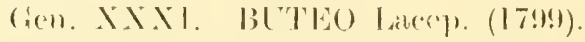

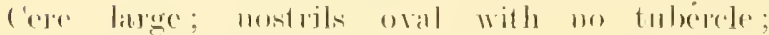

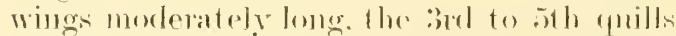

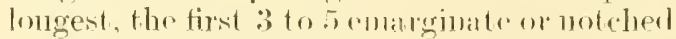
on inner wolds ; tapsus short, strong. Henally seated, and feathered in front for a varying distance. Size molally under 24 in. 
Key to the Naturat Grouts and Spectes (ADUtos).

1. Tatil nustally lnown. sometimes washed with

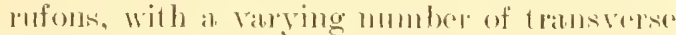
biars: generally from 6 to 12 . often indistind. General phmmage sooty-l, ack. shated with brown; tail grevish-lorown with 12 or $1: 3$ blackish bars.

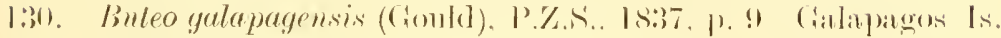
[Cialapragos $I s$.

Galapagos Buzzarel.

Aberrant species; size small ; wing $\hat{0} 10.7 .5 \mathrm{in.}$. very short and rounded ; immer welss of first 4 primaries emarginate; tips of primaries reaching to about middle of tail; tail with s or !) darker bars; plumage blackish-lprown (dark phase) or brown above and buff below and on head (light phase).

1:31. Buten solitarims Peale. Zool. U.S. Explo.

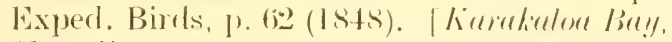
IIawaii.l

Solitary Buzzard.

Nize small; length $\hat{o} 18 . \tilde{n})$, wing $11.8 \mathrm{in.}$ : above pale brown; tail with 6 or 7 bands of darker brown: below white, throat narrowly and breast broadly st reaked with pale brown: belly and thighs miform pale brown.

132. Buteo brachypterus Hurt].. Fann. Marlag. p.l. Madagascar. (186i1). [Madagascar.]

Short-winged Buzzard.

Nize large, length $9,24.5$; wing $19 \mathrm{in}$, ; head and neek white, with hroad streaks of pale brown : aloove dull bown; tail with indistinet darker conss-bar's. the bane and inner wols white: below white. barred on throat and streaked on Joreast with dark bromen: fanks dark brown.

133. Buten hemilusins Temm. st Schl., Fum, Es. Siberia. . tapon. Ares. p. 18, pl. vii (1st4). [.Japun.] Mongolia [Archibuten strophiatus(Hodgs.)is as stnonym.] to Tibet. Upland Buzzard.

Hatwailu Arrhipelatgo

Nepal and

I. Baikal :

('心. . Tapan :

winters

('hina,

Turkestan,

N. India. 
Length ô. 19, wing 1.5 in. ; lisst 3 primaries notehed: alsose dark-bown to slate-byown with palco arlgings ; tail with 10 or 12 darker (crosi-bars, the sub-terminal broad; throat white, upjer loreast infous (ô) to deep ehestnut or brownish-black (9): other lower parts buffy-white, gemerally with rufous arrow heads or Hank bars : a miform sooty-brown phase is met with.

1:34. Buteo suainsoni Bonal). Geogr. and Comp. [ist, p. 3 (1838). [Neur the C'olumbia River.] swainsom's Hawk.

Thil howr with 8 or ! darker bars: below whitish, hoavily blotched lengthwise with rark brown ; thighs buffish, harred with dats brown.

1:35. Bunteo oreophilus Hart. and Nemm., Orn. M.В. xxii., p. 31 (1914). [\$. Abyssinia.] li. African Buzzard.

Finst 4 primaries notebed ; length of about 20 in.; wing 14.75-15: tail 8.75-9) ; tassus 3.10 ; o wing 15-16 in.; plumage variable; adult in breeding phmage (Brit. Isles) brown to (lark brown above, sometimes with rusty edges to scapulars; lower parts whitish, bearily blotcherl on brast and barred on belly with chati brown (oceasionally rufous hown), the mpper breast, flankis and thighs nearly miforms; tail with 12 or 13 darker bass, the sub-terminal ome hroad*; a sootyhow phase also a " white" rariety are met witl.

1:36. Buleo buteo buten (I imm.) S.N. (al. X. i. 1. (n) (1758). [Emrope.]

(ommon Brzzarl.
N. and S.

America, from

Alaska to Chile.

E. Africa.

Abrsinia and Tganda to the ('a)

IT. N. and ( Europe, N. to Brit. Isles and Swcden, S. to Sipain.

* Adults among the Buzzards usually have the tail much less numerously harped than is the case with young birds and often have a broad sub-termina I hand, lacking in young birds: the latter also have the under-parts of the hody as a rule lichter, often with the arrow-head, cireular or elongated dark markings characteristie of the young hirds of other groups of the Acripitres. Tudivicluals of all the species of Buteo vary greatty in plumage. 
Smaller insular race; darker and nore rufous; more heavily marked below, tail tinged rufous.

136a. Buteo buteo arrigonii Picchi, Avicula, vii.. Mardinia, p. 40 (1903). [Sardinia.]

Sardinian Buzzarel.

Wing 오 16.50. ja 15.50 in.; large and dark insular race; nore similar to simmermanne than typical form: daker than latter generally is and nearly miform below, blackishbrown to rufous-brown, the abdomen barred : tail with III or 12 darker bars and with or withont rufous tinge.

136b. Buteo buteo harterti subs]). nov. [B. buteo subsp.? Hart., Tög. Pal. Faun., p.l12:3 (1914)]. [Type in Tring Mus.]

Madeir: Buzzard.

Wing ô 13.40-14.10; + $14.70-15.2 .5$ in.; rufous form, but tail generally light ashy, with 7-9 bars, the sub-terminal hroad, more or less tinged with rufous; below with belly either uniform deep rutous or barred and mottled with buffish-white.

136ic. Buteo buteo rothschildi, subsp. nov.* [No. Azores.

1904, 12. 31. 286, Coll. B.MI., O Terceira. Az. Apl. 6, 1903. M.R.(). Grant.]

Azores Buzzard.

Wing 오 15.40-1.5-70. $\hat{\jmath}$ (jur.) 13.80 in. ; rufolls form : ehest and a bdomen rufous brown; tail brown, slightly tinged with rufous and with the darker bars nearly obsolete in rery old bird, about is being apparent: younger birds have about 10 distinct bars.

1:36il. Buteo buten insularum Floericlic, Mitteil. ('anary"

Oesterr. Rejchsb, iii., p. (it (1903). [rran Isles.

Canaria.]

Canary Isles Buzzald.

Paler and less rufous than throe preceding forms; wing 14.60; above ashy-brown, with paler margins to the feathers: tail with !) clarker bars: below throat white, streakerl with dusky-brown: chest brown, mottled with buffy-white; centre of breast whiter ; belly

* The fine series in Brit. Mus. foes not appear to me to confirm the view that the Azures race is the same as the Canary Is. race. 
barred with brown; thighs dark brown, slightly barred with rufous; feet smaller and slighter.

136e. Buteobuteo bannermani, subsp. nov. [S Near Cape Verd II indello Bay, St.Vincent, Cape Verd Is. Sept. Islands. 26, 1913, in C'oll. B. М. No. 1919. 8. 15. 148.] Cape Verd Buzzard.

Size of but more rufous than $B$. buteo buteo; more heavily marked below; abdomen and under tail-eoverts white barred transversely with rufous brown ; tail distinctly barred and with a rufous tinge; wing 14.32 , tail 8.25 in.

136f. Buteo buteo zimmermanna, Ehmeke, J.f.O. 1893, p. 117. [Kreis Gumbinnen, E. Prussia.] Pufous Buzzard.

Tarsus feathered about half-way down in front; plumage above purplish brown, with rufescent margins; tail with 4 or 5 indistinet darker bars; below rufous, abdomen buffywhite, barred with rufous (younger birds buffy-white below, streaked on breast and blotehed on abdomen with dark brown.)

136g. Buteo buteo japonicus (Temm. et Sehl.) in Siebold's Fauna Jap. Aves., p. 16. [pl. vi, via] (1844). [Japan.] $[=B$. plumipes. (Hodgs.)]

tapanese Buzzard.

Jajan, China

Corea,

Manchuria,

Turkestan,

Pumjal, to

Burma.

B. Tail more definitely red in old birds, with most of the bars obsolete.

Smaller : wing ô 13.40-14.50, tail 7-8, tarsus 3 in. \& wing about 15 in.; above brown

* There are eight rufous Brit. birds in the Brit. Alus. collection, two of which seem referable to $B$. rufiventer and the rest to this form, while there is another example in Brighton Mus. from the Monk coll., lahelled "England." Devonshire birds are, however, often almost as rufous as those from E. Europe. 
with conspicious rufous margins and blackish shafts; tail more or less lufous, with subterminal band and rentains of other bars (in younger birds ashy-brown barred with dark brown); head, neek and under parts tawny rufous, breast varied with creamy buff and throat streaked with brown: belly not barred in adult.

137. Buteo rufieenter Jerd. Madr. Jul. 1S44, 1). 165. [Nilghiri Ilills, Indiu.] $[=B$. desertorum Daud. ex Levaill.]

Desert Buzzard.

II. Asia and

S.E. Enrope*

(S. Russia to

('ancasus) ;

S. to India,

Arabia and

Africa below

the Sahara

in winter ;

(as, in Brit.

lslands.

Much larger : Wing ô 16.25-17.75, tail 10.5, tarsus 3.75 . 옹ing $18-19$ in. : breast buffish to pale rufous with dark shaft streaks; ahdomen, Hanks and thighs rufous to chocolate brown, unbarred; tail pale rufous. whitish at base and shafts white, with 2 or 3 definite bars towards tip and remains of others; nniform dark uncler parts of some birds probably a dark phase or erythrism rather than age: also smbject to melanism: immature buffish white below blotehed and streaked with dark rufous brown; tail ashy with darker bars.

138. Buteo feror ferox S'. G. Gmel., N. Comm. lc. Petrop. xi.. p. 442, pl. x (1769). [Astralian.]

Jong-legged Buzzard.

S.L. Europe

(cas. S. \& $\mathrm{II}^{r}$.

Europe),

ligypt,

Arablia, Asia

Minor; 11 .

\& ('. Asia ;

N.W. Inclia

and Africa

in winter.

* The form B. menetriesi, Bogd., is not separable. It appears to rest upon birds with a fully rufous tail and the bands obsolete, exeept the subterminal one, but there is no doubt these are only very old birds and there is no means of distinguishing European from Asiatie examples in the various other stages of tail marking, while the red stage seems common to both. Botl forms migrate to Africa. 
Much smaller: wing 14.50, tail 8.2 , tarsus 2.7 in.

138a. Buteo ferox cirtensis (Levaill). Expl. Sci. de l'Alger., pl. 3 (1850). [Algeria.]

Algerian Buzzard.

Length ô 21 , wing 17 , tail $s$, tarsus 3.30 in. : ㅇ length 23, wing 18 in.; general plumage sooty or brownish-black; lower breast chestnut; abdomen more or less barred with white and chestnut; primaries externally ashy, secondaries whitish, both hatred with black; tail chestnut red, with black sub-terminal band; younger birds have under parts rufous, excepting throat.

139. Buteo jakal (Daud.), Traité, ii., ]. 161 (1800). [Cape of Good Hope, ex Le I'aillant.] Jackal Buzzard.

139a. Buteo jakal archeri W. Scl., Bull. B.O.C., Somaliland. xxxix., p. 17 (1918).

Size similar ; tail less chestnut, more tawny : lower parts black in old birds; in younger chicfly white, excepting the throat which is morc or less black.

140. Buteo angur Rï̈pp., Nene Wirb. Nög., p. 3s, pl. 16 (1835). [Abyssinia.]

Angur Buzzarrl.

General plumage of $\hat{o}$ dusky blackish, the feathers of back and wings margined with brown; sides of head and cerrical collar varied with rufous: forehead, nape spot and throat white; breast as upper parts; abdomen and flanks white spotted and streaked with black: tail rufous with subterminal black band.

141. Buteo auguralis Salrad.. Att. Soe. Ital. Sc. Nat., viii., p. 377 (1865). [Abyssinia.] Salvadori's Buzzard.

Size variable; a verage length, 0721 , wing 15.51 in.; 오 24. wing $17.50 \mathrm{in}$; above blackishbrown with more or less of lighter variegation : tail chestnut with onc sub-terminal darker band and often remains of others; helow luffy-white, Hanks barred or mottled and abdomen heavily streaked with blackish-brown.

N.II. and $\mathrm{N}$. Africa, (Moroceo, Algeria, Thunis), Spain (ace. ?)

s. Africa.

N.E. Africa, Equatorial Africa.

W. Africa to N.E. Africa. 
142. Buteo borealis borealis (Cmel.), S.N., 1. 1). 266 (1788). [Carolinu.]

Reel-tailed Buzzard.

¿. North

America, $N$.

to Canada

and New-

foundland

W. to Git.

Plitine.

light form, pure white below with few or no markings: sub-terminal tail-bar reduced or obliterated.

142a. Buteo borealis krideri (Hoopes). P'r. Ac. Nat. soc. Philad., 1873. 1. 238. pl. 5. [Iou'a.] Kriller's Hawk.

Gt. Plains, from Missouri and Minnesota, II. to Rocky Iountains, N. to S. Manitoba.

Strongly de veloped form of $B$. borealis borealis, more strongly marked below, espeeially on thighs, and with more bars than the sub-terminal one on tail; melanisms are frequent, but they usually retain the rufous tail.

142b. Buteo borealis calurus (assin. Proc. Ac. Nat. Sei. Philad., vii., p. 281 (1855). [Nem Mexiro.] Western Red-tail.

\section{North America, be- roud IV. edge of Gt. Plains E. to Middle Yukon, S. to Guatemala ; Guadalonpe Is.}

Perhaps a melanism of $B$. borealis borealis: size similar, but more robust; nearly uniform sooty-brownish-black, with much less of concealed white; tail mottled with grevish, dusky-white and rufors, with subterminal black band.

142c. Buteo borealis harlani (Aud.), Bds. Am., i., p. 86 (1830). [Lonisianu.] Harlan's Buzzard.

Lower

Mississippi

Valley \& Gulf States, from Lonisiana to Georgia and Florida. 
Resembling $B$. borealis calurus, but smaller throughout; wing ô ad. $344 \mathrm{~mm}$. : 9365 $\mathrm{mm}$.; dark areas blaeker and more extended.

142d. Buteo borealis alascensis Grinnell, Univ. Cal. Pub. Zool., v., No. 2. p. 211 (1909). [Glacier Bay and Chichagof I.]

Alaskia Red-tail.

Tail uniform rufous, with one very narrow sub-terminal band: Hanks and thighs light rufous; juv., tail barred, and flanks and thighs sparsely barred with rufous.

142e. Buteo borealis costaricensis Ridgw. Hist. N. Am. Bds., iii., p. 285 (1874). [Coste Rict.] C'entral American Rerl-tail.

Size of B. borealis borealis, but darker abore; throat and middle of belly with broad eonspienous striping and banding of deep chocolate brown: tail feathers with darki brown markings (remains of bands) near shaft.

142f. Buten borentis umbrinus Bangs, Pr. New Engl. Florida, Zool., Cl. ii., 1. 67 (1901). [Myalila, Bahamas. Manatee Co., Florida.]

Florida Rerl-tail.

Small form : wing ô 14.94-15.70, $916.76 \mathrm{in.}$ Insular race, undescribed ?*

142g. Buteo borcalis socorroensis Pidgw., Pr. U.S.N. Socorro Mus., iii., 1880, p. 220 (1881) [Socorro I.] Island. [nom. mudem.]

Socorro Island Red-tail.

More rufous on sides of breast and belly; thighs heavily barred with brown.

142h. Puteo borerilis fumosus Nelson, Pr. Biol. Tres Marias soc. Wash. xii. p. 7 (1898) [Tres Marias Islands. Is.]

Tres Marias Red-tail.

Length 21, wing $14.50 \mathrm{in}$; above sootybrownish with purplish gloss and ferrnginous elgings ; tail rust y ferruginons, base and tips white with sub-terminal dusky-black band and 7-9 dusky bars; wing quills rieh brown, barred with black; below white tinged

* The example in Tring Mus. is black with rufous tail, having broad sub-terminal band, and $\mathrm{S}$ or 9 narrow obsolete bars, presumably a melanism. 
buff; throat streaked with dusky, ehest more thickly with ferruginous; a clusky zone across abdomen; thighs barred ferruginous.

143. Buteo tropiculis Verrill., Pr. Ac. Nat. Sci. Philad. Ixi. pp. 357-S. (1909) [San Lorenzo.]

Tropical Buzzard.

Doubtful species: "Possibly the light phase of B.b.harlani." A.O.U. Check list; only type example known.*

144. Buteo cooperi Cassin. Pr. Ae. Nat. Sici. Califo_nia. Philad. 1856, 1. 253. [Santa Clara Co.. Calif.] Cooper`s Buzzard.

C. Tail black.

Smaller than $B$. borealis borealis; average length, o, 19, wing 12.50 in.; plumage above reddish brown with darker ecentres; lesser wing-eoverts bright chestmut: below pale brownish rufous, barted with white; thighs paler and more buffy ; quills and tail baek, barred with white, the tail with about 6 hars.

14.). Buteo lineatus lineatus (Gmel.), S.N. I., P. 268 (1788) [Long Is., N.Y.] Red-shouldered Buzzard.

Wuch darker : "An erythrism of last form " (Cones); below generally mueh darker reddish, with mueh less white barring; thighs rufous.

14.5. Buteo lineatus elegans Cassin, Pr. Ac. IV. North Nat. Sci. Philad, vii, p. 281 (18.55) [Cali- Ameriea fornia.]

Westorin Red-shouldered Buzzard

Smaller : wing 11-12 in.

1451). Buteo lineatus alleni Pidgw., Pr. U.S. Nat. S. Carolina Mus. vii., p. 514 (1885) [Tampa, Fla.] to Florida. Florida Red-shonldered Buzzard.
E. North America, N. to Canada, W. to edge of Great Plains. from Brit. Colombia to N.IV. Mexico and Lower California.

* A.O.U. Check List, ed. 3, 1910, but Gurney (Ibis, 1876, p. 242) refers to another from Colorado. 
Wing (type) 12.98 ; tail 8.62 in. ; darker, ap)proaching B.l. elegans ; breast usmally more spotted with buffy : dark shaft of chest more conspicnous; head and back more rufous.

145e. Buteo lineatus texanus Bishop, Ank., xxix. p. $232(1912)$. [Texas.]

Texan Red-shonldered Buzzard.

Considerably smaller : length ô 15 , wing 10.75 in. : ㅇ 16 , wing $11.40 \mathrm{in.}$ : only 3 outer primaries emarginate: plumage above dark brown with lighter edges; nape mmeh mottled with white; tail brownish-black with $\because$ bands of grevish-white ; below rufous brown cross-harred with white in the form of transverse oblong spots.

146. Buteo platypterus platypterus (Vieill.), Tabl. Enel. Meth., iii.. p. 1273 (1823). [Near Philadelphia.

Broad-winged Buzzard

Texas,

Mexico.

E. North

America ;

C. America.

Colombia.

Ecuador.

E. Pern

(winter.)

Insular race: smaller and lighter than antillarm and bars below narrower and less sharply defined.

146a. Buteo platypterus insulicola Riler, Ank., Antigua. xxy., 1. 273 (1908). [Antigna.]

Larger and darker.

146h. Buteo platypterus antillarum Clark, Pr. St. Vincent, Biol. Soc. Wash., xviii., p. 62 (1905). [St. St. Lucia, Tincent.]

Grenada.

[Deseription not seen.]

14fic. Buteo platypterus rivieri Verrill, Adu. to Dominica. Avif. of Dom. ea. 190.5, p.---?

Smaller ; wing ô (Surinam) 15.2.5in.* ; general plumage black: tail black with broad median band of grey (showing white below) and remains of a second band.

* Examples from Mexico (Tring Mus.) are larger ; wing $\widehat{o} \mathbf{1 6 . 7 5} \mathrm{in}$. A 우 (?) Bolivia has the wing is in., and if this is a migrant from Mexico, there may be a large northern race, and if so it conld be ealled mexicanus. Gray's albonotatus (Mexico) is a nominum nudem and cannot stand, while Kaup's albonotatus (Isis, 1847, p. 954) is neither a name nor a description. His albonotatus in Contr. Om. 1850, p. 75, is from "S. America " and is based on the "concealed white spots," which can be seen on the Surinam bird at Tring, and not on the Mexican ; they appear only to mark a stage of plumage. The only certain clistinetion seems to lie in the relative sizes. 
147. Buteo abbrevialus abbreviatus Cub., in Brit. Ciniana, Schomb. Reis. Guiana. iii, p. 739 (I848) Surinam, [British Guiana.]

Zone-tailed Buzzard.

Brazil,

Venezuela, Mexieo,

Arizolla, New

Mexico,

'Texas, s. to

Bolivia.

Much smatler; wing ". " 12.50 ; tail 6 in. ; uniform sooty black; tail with 4 grey bar above, showing white below.

147a. Buteo abbreviatus minimussubsp. nor. ["o " s. Brazil. Miritiba, Braz., 18.5.09, coll. H.K.S.]

D. Tail white.

Lengtho 22 ; wing 15.25 in. ; general colom of of bluish-slate; tail white with about! narrow bars of slate grey and broad subterminal blackish band; $Q$ head, neck and upper breast slate; mantle, seapulars and belly rufous.

148. Buteo poliosomus (Quoy et Gaim.) Voy. ('hile, de l'Uran. Ois. p. 92, pl. 14 (IS24) [" Hes Malouines."]

Falkland Island Buzzard.

Patagonia, Falkland Is., Tierra del

viego.

Size similar ; alult $\hat{j}$, gencal plumage slate, tail with \& darker bars and broad black subterminal band; abdomen and thighs slate, nore or less barred with white; o wings, rump and belly more or less suffused with rufous; thighs rufous bared with white.

149. Buteo hypospodius Gurney, [bis, 1876, 1). Colombia, 7:3, pl.3. [Medellin.]

Girey-bellied Buzzard.

Larger: wing (Q ?) 19 in.; above and tail much as in $O$ of $B$. e. erylhronotus; below barred with white and slate, the breast mixed with riffous.

150. Buteo pocilochrous Gurney, Ibis, 187!), 1. Ecuador, 176. [Yanayacu.] $[=B$. melanosternns. Реги, Berl. and Stolzm.]

Gumey's Red-backed Buzzard.

Bolivia, Chile, Argentina. 
Length ô 21 ; wing $15 \mathrm{in}$; ㅇ wing $16.5 \mathrm{in}$.; of above slaty-blue, below white; tail white with 10 or 11 narrow grey bars and subterminal blaekish band; o back and scapulars brick red.

151. Buteo erythronotus crythronotus (King) Patagonia to Zool. JnI.iii, p. 424 (1827). [Str. of Magellan.] Chile and Red-backed Buzzard.

Peru, Falkland Is., Argentina.

Insular form; ô darker slate grey above; back uniform like ${ }^{\hat{x}}$ instead of red.

15la. Buteo erythronotus exsul Salvin, Ibis, 1875, p. 371 [Masafuera.]* Masafuera Buzzard.

Length ${ }^{1} 21$, wing $17 \mathrm{in}$; a above and throat slaty-grey, darker on head and wings; shoulder ferruginons; r'ump and npper tailcoverts white: tail silvery grey, eentre feathers white, with 8 or 9 silvery bars and sub-terminal black band; below white, axillaries and flanks barred with blackish.

152. Buteo albicaudatus albicaudatus (Vieill.), N. Dict. d'Hist. Nat. ir, p. 477 (1816). [S'. America.]

White-tailed Hawk.

Cross bars on tail and lower parts finer and more broken.

152a. Buteo albicaudatus sennetti Allen, BuII. Am. Mus. N.H. v., p. 144 (1893). [Texas.]

Semnett's White-tailed Hawk.

Masafuera Island.

S. America, to Chile and Argentina.

Middle

Texas to

S. America.

"Notably smaller: with the npper parts, particularly the head and sides of the neek, darker and more slaty."

152b. Buteo albicaudatus exiguus, Chapm., Bull. Llanos of Am. Mus. N.H. xxxiv., p. 637 (1915). E. Columbia [Barrigon, Col.]

Columbian White-tailed Hawk. \& E. into Venezuela.

* The following additional forms of Buteo have been described from Chile by Philippi (Areh. für Naturg., 1899, pp. 167-70) viz. : Buteo melanostethos, B. pocilogaster, B. macronychus, B. ater, B. pictus, B. albigula, B. [Asturina?] rethiops et elegans, but what the respective value of these forms is I have been unable to judge. 
Ad. plumage not seen ; imm. black, abdomen somewhat barred with buff; tail witl indistinct darker bars. [Tring Mus.]

152c. Buteo albicaudatus colonus Berl. .J.f.O. 1892, p. 91. [Curacao.]

Curacao White-tailed Hawk

\section{Gen. XXXII. ARCHIBUTEO Brehm}

$(1828)$

With charaeters and appearance of Buteo, but tarsi feathered to the toes.

Length ô 26 , wing 18.7 in. ; q length 22.5, wing 17 in. : above deep brown with paler margins: head, neck, throat and ehest white, streaked with dark brown; scapulars and least wing-coverts with white bases: upper tail-coverts banded with white; tail white, terminal portion ashy, with sub-terminal blackish band: centre of belly and flanks decp brown mottled with white; thighs and tarsi buffish-white, barred with brown; mueh variation occur's, some birds being much darker, almost uniform below.

153. Archibuteo lagopus lagopus. (Gmel.), S.N., i., 1. 260 (1788). [ex Brinn.; Christiansoe near Bornholm.]

Rough-legged Buzzard.

Much paler; phumage above with broad white margins; streaks on throat and breast and thighs much narrower and paler; upper tailcoverts white with a eentral streak of brown.

15:ia. Archibuleo lanopus pallidus (Menzb.), Orn. 'Tumkest., i., 1. 163 (1888). [Siberia, T'urkestan, ctc.]

Siberian Rough-legged Buzzard.

Much darker and more ochraceous betow normally than $A$. $l$. lagopus and varying in melanistic examples to nearly nuiform black.

153b. Archibuteo lagoms sancti-johannis (Gmel.). S.N., i.. 1. 273 (1788). [Hudson Strait and Newfoundland.]

American Pough-legged Buzzard.
Curagaro, Bonaire, \& Aruba Is

N. Lurope and N. Asia; in winter S. to Mediterranean, Black Siea and Caspian.

Siberid, Turkestan, Kamtschatio Ussuri.

N. America, $\mathrm{N}$. of Mexico, breeding $\mathrm{N}$. of U.S 
Plumage above blackish with ehestuut margins; head streaked with black and white; tail silvery ashy, tinged with rufous, the hase and tip white; below white, with black shaft lines on breast and arrow heads on flanks; legs bright chestnut barred witl black.

154. Archibuleo ferrugineus (Licht.), Abh. K. W. North Akad. Wiss. Berl. (Phys. Kl.), 18:35, 1. 428 America, s. (1839). [Near Monterey, Cal.]

Ferruginous liough-leg.

to California ; in winter to

Lower

California and N. Mexico.

Gen. XXXIII. BUTEOLA B̉p. (185.5).

Nostrils round, with distinct central tubercle; wing with 3 outer primaries emasginate on innes webs, the 4 th sinuate.

Size moderate; length ô (?) 15.5. wing 11.3 in.; 9 (?) 16, wing 13 in. Above slaty-black: tail ashy-brown, tipped with whitish and with 4 bars of blackish-brown; sides of face and under surface of body white; molanistic variety $[B$. fuliginosa, Scl.] immature?, general plumage sooty-black; tail brown with 8 blackish bands.

155. Buteola brachyura (Vieill.), N. Dict. d'Hist., Nat.iv., p. 477 (1816). [Cayenne].

Short-tailed Buzzard.

Brazil,

Bolivia,

Perı, Guiana, N. to Central America and Florida.

Gen. XXXIV ASTURINA Vieill. (1816).

'Tibix long ; feet large and powerful ; nostrils round, with indistinct and concealed tubercle at base of upper margin. Size medium (length 16-18 in.).

$\hat{\jmath}$ ㅇa above ashy-grey, barred with sil very white, most narrowly on the head and nape, bars becoming duller and broader on wings ; upper tail-coverts blackish, tipped with white; tail blackish with a broad white band about $\frac{1}{3} \mathrm{rd}$ of distance from tip and a second incompletc band on outer feathers ; body below regularly banded with silvery white and slaty grey. 
156. Asturina nitida nitide (Lath.), Ind. Orn, i., S.E. Brazil, P. 41 (1790). [Cayenne].

Shining Buzzard-Hawk.

Amazonia,

Guiana,

Colombia to

Panama.

[Not seen.]

156a. Asturina nitida pallida Todd, Proe. Biol. Soe., Bolivia, Wash., xxviii.. P. 170 (1915).

Above ashy-grey without white bars; head and napelighter; tail with whitish band across middle with remains of another nearer base, below banded as $A$. n. nitida, except on breast, which is ashy-grey with black shaft stripes.

157. Asturina plagiata Schl. Mus. Pays-Bas, i., Asturinæ, p. 1 (I862), [Tera Cruz].

Mexican Goshawk.

Costa Rica, N. to S.

Arizona and

Lower Rio

Grande

Valley.

\section{Gen. XXXV. RUPOPNIS Kaup (1844).}

Feet and claws much smaller and weaker.

Sizo rather smaller than Asturina.

Jength ô 14 . wing 8.70 in.; above pale ashy. grey ; tail light ashy with 3 broad bands of blaek; inner webs of wing quills rufous, harred with black, onter webs and tips ashy brown; below white, barred with palr. rufous or rufous ashy, the whest and throat nearly uniforme.

1.5s. Rupornis maynirostris maynirostris (Gmel.), S.N., i., p. 282 (17ss). [('eygenne].

Large-biłled Hawk.

Guiana,

Venezucla, Colombia, Peru, Lesser Antilles.

[Not seen.]

1.isa. Rupornis magnirostris occidus Bangs, Pr. Biol. Peru. Soe, Wash.. xxir., p. IS7 (19ll). [Rio Tembopata.]

Bangs's Hawk.

Above browner ; tail with interspaces ashy. 158h. Rupornis magnirostris griseicauda Pidgw., Pr. Bos. Soc., N.H., xvi., p. 47, (1873) [Mexico?]

Mexieo to Guatemala and $N$.

Nicaragua 
Smaller; much paler (smoke grey) above ; slightly paler below.

159c. Rupornis magnirostris conspecta, Peters, Ank, Yucatan 1913, p. 370 [San Ignacio.]

Peninsula.

Tail with the interspaces rnfous instead of asiny; below buff banded with rufous, throat and chest ashy.

158d. Rupornis magnirostris ruficauda (Scl. \& SaIv.). P.Z.S., IS69, p. 133 [TY]pe toc. sugg. David, IJ. Panama, Chapm.].

Red-tailed Hawk.

Central

America

(S. Nicaragua

to Panama.)

Insmlar race.

158e. Rupornis magnirostits gracilis Ridgw., Pr. Cozumel U.S.N. Mus., viii., p.94(2885). [Cozumel 1.] I. Yucatan.

Length ㅇ 14.50, wing $10 \mathrm{in.}$; tail dark brown imperfectly banded with white and shaded with dull rufous; below dark rufous narrowly banded with white.

1isf. Rupornis magnirostris ridguayi C'ory, Auk, i., p. 4 (1S84). [S. Domingo].

Haiti and SS. s. Domingo.

Larger ; above brown, darker on head ; quills paler rufous than in $R . m$. ruficauda, and with bases pale rufous externally ; tail pale rufous banded with dark brown ; below buffy-white, very narrowly and indistinctly barred with pale rufous.

1.58g. Rupornis magnirostris pucherani, J. \& E. Verr. Rev. et Mag. de Zool., 185̃, p. 350 [type loe. suge. Paraguay, Brah. \& Chubb.]

Above ashy brown, head mnch clearer ; tail with the interspaces ashy-brown; throat ashy-grey ; chest pale rufous, rest of under parts fulvous barred with pale rufous.

158h. Rupornis magnirostris nattereri (Sel. \& Salv.) P.Z.S. 186!, 1). 132. [Sao Paulo et Brazil. Matlogrosso.]

Natterer's Hawk.

Uniform black, lower upper tail-coverts and hase of tail white; tail black, with a single band of ashy-brown ; tibial plumes rufous ; under tail-coverts buffy-white.

Paraguay, S.J. Brazil, Bolivia, Argentina.

S.E. \& C. 
159. Rupornis leucorrhos (Qnoy et Gaim.), Voy. Brazil to de l'Uran. p. 91, pl. 13 (1824). [Brazil.] Peru, White-rumped Hawk.

Colombia, Venezucla .

\section{Gen. XXXVI. BUSARELLUS Lafr. (1942.)}

Size of Buteo; sole of font covered with ringose and throny spienles (like that of Pandion) tip of npper mandible much eurved.

Above bright chestnut, with narrow blaek shaft stripes; outermost wing-eoverts and quills black; basal half of tail chestnut banded with black, apical half blaek with narrow white tip; head and neck creamy buff; lower throat black; below chestmut.

160. Busarellus nigricollis (Lath.), Ind. Om. 1, p. $35(1790)$. [C'ayenne.] Black-collared Hawk.

Brazil,

Guiana,

Peru,

Paraguay.

\section{Gen. XXXVIT. BUTEOGALLUS Less. (I831.)}

Size nearly the same; outer toe hardly longer than inner: soles of feet smooth, wings short of tail by less than length of hind toc.

Plumage above black, with rufous margins on mantle and wing-coverts ; quills bright chestmut, the onter webs black; tail black with white tip and indistinct median band of white; throat blackish; below rufous, narrowly barred with black.

161. Buteogallus requinoctialis (Gmel.). S.N. i. p. 265 (1785). [Cayenne.]

Equinoctial Buzzard.

Guiana ; Colombia, Paraguay.

Gen. XXXVIII. URUBITINGA Lafr. (1837).

Rather larger: tarsus scntellate before and behind, reticulated laterally ; distance between tips of wing and tail greater than !ength of hind toe : secondaries nearly as long as primaries; general plumage black.

Above and below black ; upper tail-coverts mostly white; basal half of tail white with a broad black band: apical half black with white tip. 
162. Urubitinga urubitinga urubitinga (Gmel.), Chile,

S.N. i., p. 265 (178S). [Brazil.] Argentina, Brazilian Eagle.

Paraguay,

E. Peru,

Brazil,

Venezuela,

Guiana,

C. America

to Costa Rica

Under wing-coverts and tibix with more white; tail with less white and an extra black bar.

162a. Urubitinga urubilinga ridgwayi Ginney, Guatemala List Diurn. Bds. Prey, p. 77, 148 (1884). and Mexico. [Gualemala.]

Pidgway's Black Hawk.

162b. Urubitinga urubitinga subtilis Thayer and S.IT.

Bangs, Bull. Mus. Harvard. xlvi. p. 94. ('olombia. (1905). [Gorgona I.]

Gorgona Black Hawk.

Black above and below; upper and inder tailcoverts narrowly tipped with white; tail with a broad white median band and white tip.

163. Urubitinga anthracina anthracina (Licht.), Tropical Preis. Verz.; Vogel, Mexico, etc., p. $3(1830)$. America to [Mexico.]

Mexican Black Hawk. IV. Indies, Guatemali, Nlexico and Arizona.

Joubtful form; said to be dark chocolate brown with 2 more or less distinct extra white bands at base of tail.

$\downarrow 163 \mathrm{a}$ Urubitinga anthracina gundlachii Cab., J. Cuba. f.O. (1854). [Cuba.] Cuban Black Hawk.

\section{Gen. XXXIX. LEUCOPTERNIS Kaup (1847).}

Similar in structure to Urubitinga; nostril nearly cirenlar; tarsus not more than twice as long as middle toe; plumage usually more white than black.

Plumage uniform bluish slate colour; tail black, with a white median band and white tip. 
164. Lencopternis schistacea schistacen (Simnder.) Efv. K. Tet. Akad. Förl. 1849, p. 132. [Brazil.]

Slate-colonred Hawk.

Smaller : Uniform leaden grey ; wings and tail blaek, latter with a median bar of ashywhite; under wing-coverts white and tibial plumes barred with same.

164a. Lencoptemis schistacea plumbea Salv., This, 1872, p. 240, pl. viii. [Ecnador.]

Plumbeous Hawk.

General plumage white; head streaked with black, neek all round white; mantle and wing-coverts black varied with white ; (puills black; tail white with broad sub-terminal black band.

16.5. Lencopternis albicollis albicollis (Lath.), Ind.

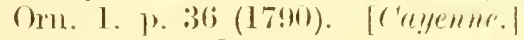

White-eollared Hawk.

Similar, but rather smaller and with heard phumbeons; npper parts plumbeons instead of black; black sulb-terminal band on tail narrower.

16ĩa. Lencopternis albicollis occidentulis Sialv. IT. Ecundor. Ibis. 1876, p. 496. [I'mma $I$.

Puna White-eollared Hawk.

Larger; above and below white; tail with broal sub-terminal black band; greater wing-coverts and secondaries black tipped with white; primaries black.

166. Lencopternis ghicshrechti, Du Bus. Earq. On. pl. 1 (1845). [s'. Merico.]

Ghiesbrecht's Hawk.

Above blackish-slate: most of feathers tipped or barred with white; head, neck and underparts white; basal half of tail black, torminal white.

167. Lencopternis palliate (Pelz.), Sitz. Akad. S. Brazil. Wien. xliv., p. 11. (1861, cx Natterer.) [Ypanema.]

Mantled Hawk.
E. Рети

Colombia, C. and N.E. Brazil.

Ecuador, IV. Colombia

Guiana, Trinidarl, Venczuela, N. Brazil.

S. Mexion to Panama. 
Above more slate coloured, with less white variegation: neck shaded with greyish ; tail with narrow sub-terminal black band on white apical half.

168. Leucopternis lacernulata (Temm.), PI. Col. S.E. Brazil 1, pl. 437 (1827) [Brazil.]

White-headed Hawk.

Smaller: above slate-black; above eye a white stripe, and nape streaked and margined with same; tail black, tipped with ashy brown, with a median band of white ; below white narrowly streaked with black on sides of chest.

16!). Leucopternis kuhli Bp).. ('onsp). Av. 1, p. 19, N.E. Brazil. 1849. [Para.]

White-browed Hawk.

Above black; head, neek and lower parts white; lores and stripe behind eye black; crown and nape streaked with black; tail black with broad band of white about $\frac{1}{3} \mathrm{rd}$ from end.

170. Leucopternis melanops (Lath.), Ind. Orn. 1, p. 37 (1790). [Cayenne.]

Black-faced Hawk.

Above miform plnmbeous; wings and tail black; latter with a narrow band of white near middle: below white with a few black shaft stripes on sides of breast.

171. Lencopternis semi-plumber (Lawr.) Ann. Lye. N.Y. vii., p. 288 (1861). [Panama.] remi-plumbeous Hawk.

Above, also throat and foreneek, slaty-black, below white narrowly barred with black; tail black with a median band of white. and a few anterior incomplete bars of same.

172. Leucopternis princep.s Sclat.. P.Z.S. 1865, p. 429, pl. xxiv. [Costa Rica.]

Barred Hawk.

Guiana :

N. Brazil.

Colombia and Panama to Costa

Rica.

Costia

Rica.

N. Eemador.

Gen. XL. HARPYHALIAETUS Lafr.

Nuch larger than Buteo; Head with a long occipital crest; tail short. not three times as long as tarsus. 
Length ad. 33, wing 22 in.; tail 13.5 in.; above and below ashy-brown, shaded with chocolate; quills blackish ; secondaries ashygrey mottled with black and with a broad sub-teminal band of same; tail black, tipped with white, with broad white median band, and a second indistinct one nearer base.

173. Harpyhaliaetus coronatus coronatus (Vieill.) N. Dict. xiv., p. 237 (1817). [Paraynay.] Cromed Harpr.

Paraguay Bolivia, Patagonia. S. Brazil,

Much darker; general eolonr bluish-black. shaded with chocolate; crest much shorter.

173i. Harpyhaliuetus coronatus solitarius Treh. Arch.f. Naturg. 1844, p. 264. [Peru]. Solitary Harpy.

Chili,

Parn,

Ecuador, Colombia.

Gen. XLI. MORPHNUS Cuv. (1S17)

Size similar: head crested: tail long, more than four times as long as tarsus; toes very short; claws large.

Length 936 , wing 19.3 , tail $17 \mathrm{in.}$; above brownish-black; head and neck greyish. brown; wings barred with lighter ashybrown; tail black, tipped with whitish and with from 3 to 5 bands of ashy-brown; chest ashy-brown; below white barred with rufous or brown.

174. Morphnus guianensis guianensis (Dand.), Traité, ii., p. 78 (1800). [Ǵmiana]. Guiana Crested Eagle.

Guiana, E. Peru, Paraguay, Colombia.

Crown and sides of head dark slate; above blackish-brown; wing-coverts more conspicuously barred with white; tail with 4 bands of white, mottled and tinged with brownish-grey; throat and upper breast blackish; below closely barred with black and white.

17ta. Morphnus guianensis teniatus Gurney, Ibis, Ecuador. 1879, p. 176, pl. iii. [Sarayacu.].

Eeuadorian C'rested Eagle. 
Gen. XIII. THPASA FiTUS Gray (1837

Larger; bill robust, culmen much eurved; feet very powerful ; tarsus almost entirely bare, the scutalla rough and irregular ; claws very large and strong; head with broad depressed crest, erectile.

Length $3 \mathrm{~S}$ in. ; wing 22.30 ; above, also crest and chest-pateh, ashy grey ; tail irregularly barred with black; head, neck and underparts white.*

175. Thrasaëtus harpyiu (Limm.) S.N., i., p. S6 (1758) [Mexico].

Great Harpy Eagle.

Paraguay and Brazil; N. to Mexico.

Gen. XLIII. HARPYOPSIS' Salvad. (1875).

Size large; head crested; tail long and romnded.

Length about 34 in.; wing 19 in.; above dusky brown; below dinty white; chest grevish: tail with 6 indistinct transverse bainds.

176. Harpyopsis novre-guina. Salvad., Ann. Mus. S.I. New Giv. Genov., vii., p. 6S2 (1875). [ Yule Island.] Guinen. New Guinea Hawk-Eagle.

SUB. FAM. IV. GYPAETINA.

\section{Gen. XITV. GYPAETUS Storr (1784).}

Nostrils hidden by stiff bristles: ehin with a Jong tuft of black mistles; tarsus more or less feathered.

Size large : length 41 in.; wing 2!.50; head white, a line each side of crown and another below ear black; general plumage above black with white shafts ; wings and tail brown and seapulars washed with ochraceous brown; below tawry; tarsus feathered to the toes.

177. Gypaetus barbatus grandis Storr, Alpen- Spain, reise vom Jahr 1781, ]. 6!) (1784) [Switzer- Alps and S.E. land.] Beareled Vinture.

Europe, Central Asia, Himalayas, N. China.

* Immature birds are black above and on chest ; head and neck ashy-grey ; below white. 
Below warmer tawny l'addisll.

177a. Gypaetus barbatus barbatus p. 87. (1758.) [Africa.]

Atlas Bearded Vulture.

Jength 38 in.; wing 29 in.; cheeks white withont the black markings: tarsus bare towards lower part.

1771. Gypaetus barbatas meridionalis, Koys. and Blas., Wirbelt. Europ. p. xхтіii. (ISHO). [S. Africa.]

Southern Bearded Vulture.

\section{S'LB. FAM. V. AQULLLNA.}

Orter toe comnected to middle toe by nembrane: tibia much longer than tarsus, which is reticulated on hinder aspect and generally more or less clotherl with feather's : bill large, long and powerful ; cutting edge of npper mandible festooned, but not toothed ; wings long; tail moderate; sexes generally alike.

\section{Gen. XLY. UROAETUS Kany (1844).}

Tail strongly graduated, wedge-shaped; tarsi clothed with feather's all round to base of toes.

Size large ; length 38, wing $24.2 \mathrm{in.} \mathrm{:} \mathrm{general}$ colonx above and below black, browner on wings; nape tawny chestmut; upper tailcoverts brown mottled with white; tail feathers white at base of inner web.

178. Uroaetus andar ander (Lath.) Ind. Orn. Suppl. p. ii (1801). [New Soulh W Wales.] Wedge-tailed Eagle.

E. \& $\mathrm{II}^{\prime}$ Anstralia, Tasmania.

\section{Gen. XLV1. AQUILA Briss. (1760).}

Thil nearly sflate or moderately rounded; tarsi feathered all round: toes reticulated abore, except. last phalanx which is scaled ; head withont crest; claws powerful and emrect.

Length () 37 , wing 26 in.; plumage black, with back, rump and some of scapulars white; immature fawn colour, tail uniform.

179. Aquila verreanxi Less., Cent. Zool. p. 105, S. Africa, taf. 38 (1830). [Interior of Crape of Ciood N.E. Africa Hope.] 
Length of 32 , wing $23-24.5$ in. ; q average length 35.5, wing 26-27.50 ill.; general plumage above blaekish-brown, with paler margins : crown brown; nape and hind neck tawny rufous (W. Europe; much paler in E. European birds.); tail blackish at apical fourth, browner towards base, middle irregularly banded with grey; below blackish with brown bases to the feathers; in younger birds basal half of tail white, centre mottled brown, apical third black.

180. Aquila chrysaëtos chrysuëlos (Linn.), S.N.i., p. 88 (1758). [Europe.]

Golden Eagle.

Averaging smaller; phumage darker and duller.

180a. Aquila chrysaëtos occidentalis, Olphe-Galliard Faune. Orn. Eur. Oce., ii, fase. xviii, p. 23. (Mar. 1889.) [Spain.] Spanish Golden Eagle.

Larger : length $q 40$, wing 27.9 in.; colour generally brighter.

180b. Aquila chrysaëtos daphanea, Hodgs. in Gray's Zool. Mise. p. 81 (1844). [Nom mud.-Nepal.] Menz. Om. Turkest, 1, p. 75 (1888). [Haute Asie.]

Himalayan Golden Eagle.

Large and more rufons; max. length $940 \mathrm{in}$; wing $27 \mathrm{in.}$ [Doubtfully distinct.]

lsoe. Aquila chrysnëtos canadensis (Linn.) S.N. i, p. S8 (1758) [Canada.] American Golden Eagle.

Spain and

N. Afriea

(Morocco, Algeria,

Tunis.)

High

Central

Asia,

Himalayas.

N. America Arctic

Regions

S. to

California and

Alleghenies in N. Carolina.

Smaller ; wing ơ $23.5 \mathrm{in}$; head and neek above dull yellowish isabelline; forehead marked with dark brown, and nape tinged with rufons; general plumage blackish-brown; some of the scapulars pure white; tail clark grey with broad terminal blackish band; immature brown; tail uniform. 
181. Aquile heliaca heliaca Savigny, Deser. Egypte Ois. p. 82, pl. 12 (1809). [Upper Lgypt.] Imperial Eagle.

Size similar; forchead and crown blackish brown: edge of wing and some of seapulars white, forming a conspicuous shoulder patch ; immature fawn colour, tail miform.

1s1a. Aquila heliaca adaberti Brehm, Ber. Vers. deutseh. Orn. Ges. 1860, p. 60) (1861.) [Spain.]

White-shouldered Eagle.

Rather smalles : length 우 :30, wing $23 \mathrm{in.}$; plumage brown, palcr below; head brown, nape patch fulvous; quills, larger scapulars and tail blackish-brown, latter with fulvous tip and obsolete ashy bars; edge of wing white, forming conspienous white shoulder: immature asby-brown, tail clarker, with terminal band of fawn.

1S2. Aquila nipalensis nipalensis Hodgs., Asiat. Res. xviii, pt. 2, pl. 1, pp. 13-16 (1833). [Nepal.]

Eastern Steppe Eagle.

Smaller : wingo 21.50, 오 22.50.

182a. Aquila nipalensis orientalis Cab., J. f. O. Steppes of 1854, p. 369. [Sarepta. Volga.]

Western Steppe Eagle.

Length 0 31, wing 22 in.; jo longth 28 , wing $20 \mathrm{in}$, general colour above and below tawny to rufous brown; head and neck somewhat marked with darker blown: scapulars and wing-coverts darker brown, blotched with pale brown; quills and tail blackish-brown, with indications of greyish bars; under parts streaked with darker brown : immature tawny, tail brown tipped with fulrous.

183. Aquila rapax rapax (Temm.) Pl. Col., pl. 455 (1828). [Pte. merid. de l'Afrique.] Tawny Eargle.
S.E. Europe to C. Asia, N. India,

China, Burma .

Spain; N.W.

Africa.

Central Asia N.W. Tudia, and Li.

siberia ; in winter to Africa.

S.E. Europe and IV. Asia.

Africa, from Cape Colony N. to C. and E. Africa; C. Asia and N.W. India. 
General colour pale clay or ochraccous colonr.

1833a. Aquila rapax albicans Rüpps. Nene Wirbelth. N.E. Africa †. 34, pl. 13 (1835). [Prov. Simen, Abys.] Riippell's Tawny Eagle.

(Abysinia,

Somaliland), Arabia.

Size sinilar: length ô 28 . wing 20.5 in. : general colour fulvous brown, paler on head and neck and below, above with lighter margins to the feathers, especially on wingcoverts: tail dark brown with fulvous tip and $S$ or 9 indistinct greyish bars on centro feathers.

183b. Aquila rapax vindhiana lrankl.. P. Y.s. 1831. p. 114. [Vindhya 1/tns, Central India.] Indian Tawny Eagle.

Indian

Peninsula

and

Himalayas

Sinaller; head, neck all round amel interseapulary region chocolate brown.

183c. Aquila rapax belisarius (Levaill. jun.) Expl. Sc. Alg. Ois. 1). '2 (1850). [Guelma, N.E. Algeria.]

Algerian Tawny Eagle.

Nostrils round: length, o, about 29), wing $21.50-23 \mathrm{in.}$, $\hat{o}$, wing $20 \mathrm{in.;}$ plumige above and below blackish brown; tail nnbarred; younger birds purplish brown, mmeh spotted with brownish-buff above and striped below : tail blackish, barred dark brown.

184. Aquila clanga Pall., Zoogr. Rosso-Asiat., i, E. \& S.E. 1). 351 (1827). [In Rossia Sibiriaque universu.]

Greatcr Spotted Eagle:

Enrope, south to Balkans, E. to Turkestan, S. Siberia, N. India and China; in winter to N.E. Africa, India,

Burma ; cas. Brit. Isles.

Smaller; wing 우 19-20 in. ; o 17.70-19 ill.; phumage browner : erown and nape creamy brown: tail feathers with obsolete lighter 
bats; rounger birds less spotted than those of $A$. clangu and tail mubared: nape patch ochraceous rufous.

18.5. Aquila pomarina Brehnu. Vög. Dentsehl., C. Europe 1). 27 (1831). [Pomerania.]

Lesser Sipotted Eayle.

from N. Ger-

makny to

Bessarabia ;

(als. W.

Surope; in

winter to

N.E. Afriea.

Sexes nearly similar in size ; wing $+19.51, j$

19.15in; bill more feeble, tarsi more slender ; wings generally exceeding tail in length ; least wing-eoverts with small spots of white in immatme bioks.

Is.s.s. Aqmila pomarina hastatre (Less.), Iog. Bélang. Zool., p. 217 (18:34). [Bengal].

Long-legged Eagle.

Lndian

Peminsula :

Burmese

eomntries.

\section{Gen. XLVII. HIERAAETCS Kanp (1844)}

General elsaracters of Aquila, but hill more slender : tarsi feathered to the toes.

Length 926 . wing 21 in. : wing of $19.6 \mathrm{ju.:}$ above deep lrown, feathers mostly with paler margins and white bases ; tail ashy, with broad sub-terminal dack brown band, and is or 6 indistinct bars ; below white, with blackish-brown shaft stripes, the flanks and legs buffish. bared with black.

1s6. Hieracëtus fasciatus fasciatus (Vieill.), Mem. Soe. Limn. Paris, ii.. pt. 2, p. 152 (1822). [Montpellier.]

Bonellits Fiugle.

S. Europer (S.

France and

Spain to $\mathrm{S}$.

Rinsia).

Asia Minor,

Tirkestan,

Palestinc,

India, China,

N. Africa.

[Smaller but doubtful form.]

Isfih. Hieracëtus fasciatus minor Fulanger. ol.f.0., S. Arabia : E.

1904, 1. 187. tat. x., fix. 42.

Atrica

(Somaliland.

Ilozambique). 
Wing o $18.3 \mathrm{in.}$; above blackish-brown, mottled with white; below purer white streaked with b]ack on breast, and with large spots on under tail-eoverts; under wingcoverts black.

1S6h. Hierac̈tus fasciatus spilogaster (Bp.), Rev. et Mag. Zool.. 1850, ]. 487 [Abyssinir er Dn Bus. M.S.].

Afriean Hawk-Eagle.

Smaller : wing $916.5, \hat{j} 14.0$ : above brown, head and neek isabelline: tail with obsolete darker bars on outer feathers; below white, throat and breast washed with fawn and streaked with reddish brown or blackish ; speeies subject to variation: vounger birds dull brown below with black shatt-stripes, and a white shoulder pateh.

187. Hieracëtus pennatus (Gmel.), S.Х.. і.. ?. 272 (1788) [ex Brissom, l. є.].

Booted Fagle.
Tropieal

Afriea : rare in S. Atrica.

S. Europe (Spain to $\mathrm{S}$. Russia) ; Africa. $C$. Asia, India, Cevlon.

Smaller, and with a short oecipital erest: length ad. 21.5 in., wing 1.5 in,; above brown, erown darker; erest, neck and undersurface rufous, with black shaft-streaks ; tail mottled grerish-brown, with 7 or \& clark brown bars.

18s. Hieraätus morphnoides morphnoides (Gould), P.Z.S., 1840, p.161 (1841). [Upper Hunter, N.S.H.

Little Eagle.

Below heavily striped with dark brown.

189. Hieraaëtns weiskei Reichenow, Om. M.B., S.E. New viii., p. 18.5 (1900). [Astrolabe Mltms.] New Guinea Iittle Eagle.

Below pale isabelline : tail with 7 dark hands.

190. Hieracëtus ayresi Gurney. Ibis 1862. p. 149, pl. iv. [Natal.]

Ayres' Little Eagle $\lceil=$ Lophotriorchis lucani Sharpe.]
F. and II Anstralin.
Tropical Afriea to S. Atrica. 
Length 926 , wing $18 \mathrm{in}$; head with distinet oceipital erest : plumage above brown, with paler margins; tail dark brown, tipped with whitish, with obsolete lighter hars on inner webs of feathers; below whity brown. varied with dark browin on throat and breast.

191. Hieraü̈tus urahlbergi (Sunder.) OEf r. K. Akad. Tropieal Stockh., 1850, p. 109. [raffraria superiori Africa. propre $25^{\circ}$ lat.]

Gen. XlVIII. LOPHOTRIOR('HIS Sharpe (1874).

Head with a long wedge-shaped crest.

I ength 21 , wing $14.1 \mathrm{in}$.; above black; cheeks. throat and breast white; below tawny rufous. with blaek shaft-stripes.

192. Lophotriorchis lieneri (Geofir. St. Hilaire), Indian Rev. Zool., 1845, pl. 35. [IIimalay'a]. Peninsula, Kiener's ('rested Fagle.

Ceylon, IndoChinese

Provinces, Malay

Peninsula to Celebes and Lesser Suncla Islands.

Larger ; length 26.5 , wing 20.2 , erest $3.3 \mathrm{in}$. ; above glossy-black: tail ashy-grev, basal thirel black; throat blaek; below tawny lufous with black shaft-streaks : flanks black 193. Lophotriorchis isidorei (Des Murs), Rev. Zool.. 1845, ]. 177. [Santa Fè de Bogota.]

Isidore's Crested Fagle.

Gen. XLIX. ICTINAETUS Jerd. (1S44).

Head crested ; claws nearly straight, the circumference of inner elaw excecting the length of onter toe (which is very short).

Wing 20-20.50 in.: black: the quills mottled with white near base: tail feathers barred with ashy above, mottlec! with white below

194. Ictinaetus malayensis malayensis ('Temm.). Malay Pl. Col. i., pl. 117 (1824). [ex Reimi. MS.] Arehipzlago Malayan (rested Eagle.

(Sumatra, Borneo, ete.) 
latger: wing jo 21 .jor.

194a. Ictinaetus malayensis perniger Hodgs., Jul. As. India, sioc. Bengal, v., 1836, p. 227. [Nepal.] Ceylon, Indian C'rested Eagle.

Burma,

Nalay

Peninsula .

\section{Gen. L. SPIZIASTUR Gray (1841).}

Head crested; elaws curved and powerful ; the ciremuference of inner claw abont equal to length of outer toe and claw.

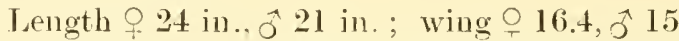
in.: above blackish, quills and tail ashy brown, slightly tipped with fulvous and bunded with black; head, neck and under surface white.

195. Spiziastur melanoleucus (Vieill.), N. Diet., ir., P. 482 (18I6). [Guiana ]

Black and Thite Crested Eagle.

Gen. LI. SPIZAETUS Vicill. (1816).

Tarsi feathered as before; crest sometimes fully developed, sometimes absent; wings short, falling short of tail by more than length of erest.

Length + 28.5 in., wing $16.2 \mathrm{in}$. ; $\widehat{x} 24$, wing $13.4 \mathrm{in}$.; occipital crest $3 \mathrm{in}$. long; sides and lack of neck bright rufous; above black, feathers brown at base ; wings brown, barred with blackish : tail brown with 4 or 5 blackish bands; below white, ehest slightly streaked and abdomen broadly banded with black; on each sicle of face below eye a black moustachial band. Young much browner and with 6 bands on tail.

196. Spizaetus ornatus (Daud.), 'Traité, ii., p (1800). [Cayenne.]

Manduit's Hawk-Eagle.

77 Central and S. America, S. to Paragllay.

Size about the same ; above and below black, browner on wings : under surface of wing with 3 irregular bands of white; upper and under tail eoverts slightly spotted with white; tail

Central \& S. America. 
black with $t$ bands of ashy brown. Joung browner above and more spotted with white below; tail with 6 bancls.

197. Spizaetus tyrannus (Wied), Reis. Bras., i., p. 300 (1820). | Rio Belmoite .

Tyrant Hawk-Walgle.

Larger; length $938 \mathrm{in.}$ wing 27.5. Above dark sepia brown: feathors of head and neek with whitish brown margins and white bases; wings barred with blackish ; tail with 6 bands of ashy grey; fore neck and chest dark brown; throat and under prarts white, sparingly spotted with dark brown, especially on flanks. Young paler above. more buffy white below, the spots nearly absent and with about 11 bands on tail.

198. Śpizuetus bellicosns (Daud.), Traité, ii., p. 38 (1S00). [Great Namaqualund.]

Martial Hawk-Fagle.

Rather smaller ; above black ; wings brown ; quills externally sharled with pale ashy grey. and with a broad subterminal banch of black: tail with 2 broad bands of ashy grey and remains of a thred; throat black: below yellowish buff, whiter towards vent, broadly banded with black, the chest almost uniform; uncter wing coverts chestmut. Iommg above brown with indistinet darkes bands and whitish margins; tail with : lighter bands: below white.

199. Spizaetus coronatus (Linn.), S.N.. ed. xii., i., p. 124 (1766). [Guinea in H. Africa.] Crowned Hawk-Fagle.

Smaller ; length o :32 in., wing 20 ; ô length ¿s in., wing 18.50 , erest 2.8 in.; above blackish brown, with paler margins, especially to feathers of head and hind neck; wings paler, banded with dark brown; tail ashy brown with 4 blackish brown bands; throat white, with black eentral stripe; chest faw
Central and s. America, from Guatemala to S.L. Brazil.

s. Africa, li. Africa, N. to Shoa, Alorssinia, and Bogosland; Nigeria.

S. and II.

Africa. 
with black shaft streaks : below brown spotted and barred with white. Young have head and neek white with dark centres to the feathers; tail with 6 darker bands; below white, slightly streaked with dark brown; flanks brown.

200. Spizaetus nipalensis nipalensis (Hodgs.) Jnl. As. Soc. Beng., v., p. 229 (1836) [Nepal]. Himalayan Hawk-Wagle.

Himalayas, S. in winter to plains of India anrl Ialay

Peninsula ; China?

With the white bands below broader and more regular.

200a. Spizaetus nipalensis lelaarli Legge, Ibis, 1878, 1). 202 [C'eylon].

Nlomtain Hawk-Eagle.

Larger; $\hat{s}$ about equal to 0 of typical race.

zolb. Spizalus nipatensis orientalis Temm. \& Schleg. N. Japan. in Siebold's Faun. Jap. Ares, 1). 7, pl. 3 (text 1S44, pl. 1845) [Japan.]

Japanese Hawk-kagle.

[Not separable muless a breeding bird in China.]

200c. Spizalus nipalensis foliensis, W. Sclat. in MS. Cat. Accip. Coll. Brit. Mus, [ô $A h$ Ch'ung, Fokien Prov. China, Coll. B.M.] Chinese Hawk-Eagle.

length 오 32 in., wing 17.8 ; ô wing $16 \mathrm{in.}$ Above brown; feathers of hind neck and mantle with pale bases and black shaft streaks; crest black, 3.8 in. long; wing quills rich frown, barred with blackish; tail with bread blackish subterminal band and :3 narrower bands; throat white with contral black stripe and bordered by 2 black moustachial stripes; below brown, nore rufous and mottled with white on chest.

201. Spizaelus cirrhatus cirhatus (Gmel.), S.N., i., p. 274 (17SS) [India].

Indian Indian Hawli-Eighte.

China.

Smaller ; wing $15.20-14 \mathrm{in.}$

20) Spizactus cirrhatus ceylonensis (Gmel.), S.N., Ceylon. i., p. 275 [Ceylon].

Ceylonese Hawk-Fagle. 
Simall insular race.

901b. Spizuetus cirhatus andamunensis Tytler, Andaman

Proc. As. Soc. Beng., 1865, 1). 112 [Port Islands.

Blair, Aud. Is.]

Andiman Hawk-Eagle.

Size of $s . c$. cirrhatus, but with crest very slight ; with dusky phase [S. limnuetus Horst.] nearly uniform chocolate brown, and pale phase [S. caligatus (Raftles)] dark brown above, below white with large longitudinal brown markings, the thighs barred.

201c. Spizaetus cirrhatus limncetus (Horsf.), Tr. Jitva, Linn. Soe., xiii., p. 138 (I821) [Java.]. Javan Hawk-Eagle.

Ślımatra,

Penang.

Larger; below white, without the dark markings.

201d. Spizuetus cirhatus floris, Hart., Nov. Zool., v., p. 46 (1898).

Lesser

Sunda Is.

(Flores).

Simaller; length al. 22.50, wing 13 in.; above black with oecipital (rest, tipped with white, $2.75 \mathrm{in}$. long; wing quills brown, tipped white, barred with black and with broad black subterminal band; tail ashy brown, with broad basal and subterminal bands of black : below white, breast with latge black spots and belly banded with black.

20.2. Spizatus albomiger (B|yth), Jul. As. Soe. Beng., xir., p. 173 (1\$45) [Malacea].

Borlieo,

Greater

Sirunda Is.,

Mala yan

Peninsula,

'Tenassorim.

liather larger, length 25 in., wing 14.7.), crest $2.50 \mathrm{in.}$; above dark $1 \mathrm{mb}$ ber brown; (rest with base of feathers white; tail paler brown with 7 clarker bands; throat as in S.c. cirrhatus; below yellowish rufous; ehest heavily marked with dark brown lanceolate spots; thighs and under talil-coverts barred with brown and white.

205. Spizaetus philippinensis Cunney, in Gould's Philippine lids. Asia, pt. xr. (1863) [Philipmine Is.] Islands.

Philippine Hawk-Eagle. 
labger ; length s 30 in., wing 21 in. : o length 24 in., wing 19.7 in. : blackish brown, blaeker on head; lighter and greyer on wings and tail; tail with $\mathbf{6}$ or 7 obsolete bars.

204. Spizaetus gurneyi (Gray), P.Z.S., 1860. 1. 34:, pl. 169. [Batchian.]

Gulucy's Hawk-Eagle.

Molucea Is., Aru Is.,

IVaigiou,

New Guintar.

\section{(ien. LII. LOPHOAETUS Kaup (1847).}

Crest feather's very long and pendant; tarsi feathered as in preeeding genera.

Size small; length ô 21 , wing 15.j(1, erest 4.75 ; ô plumage glossy blaek, with a brown shade on wings; quills white at base, forming a conspienous pateh, and bauded with white on inner webs below; tail with 3 grevish bands on middle feathers, becoming broader and whitish on outer ones ; Plarger and much browner; jux. deep rhocolate brown.

20.). Lophoaetus occipitalis (Daud.). Traité, ii., p. 40 (1800). [Anteniquoi country.]

Blaek-Crested Eagle.

S. Africa to F. and $\mathrm{I}$. Tropiea] Africa. 

PAR'T IIL-JANLARY 20, 1920.

Kus ir

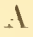

\section{SYNOPTICAL LIST}

()F 'THE

\section{ACCIPITRES}

(Diurnal Birds of Prey)

\section{PAR'T' III. \\ (Herpetotheres to Pernis)}

Comprising described Species and Subspecies, with their Characters and Distribution

BY

H. KIRKE SWANN, F.L.S.

Corresponding Fellow of Amer. Orn. Union.

LONDON :

JOHN IVHELDON \& CO., 38, Great Qdeen Street,

KingsWaY, W.C.2. 



\section{A \\ SYNOP'TICAL TIST \\ OF THE

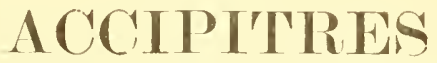

(IIURNAL BIRDS OF PRES)

\section{PAR'T III.}

Gen. LIII. HEPIETOTHERES Vieill. (1817).

Tarsus bare on lower portion, reticulated in front; bill with upper mandible slightly festooned; nostrils eircular with osseous margins; wings short.

Length ô (Ecuador) 16 in. ; wing 10.25; tail 8 in.; 의 wing 11-11.20 in.; above brown; head erested, crown buffish white with brown shaft streaks; hind part of face and broad muchal band black; fore cheek, side of neck, collar round hind neck and entire nuder parts buffish white ; rpper tail-coverts ereany buff; tail clark brown, with 4 creany buff bands in the form of pairs of oval spots not extending quite across webs.

206. Herpetotheres cachinnans cachinnans (Limu.), S.N., i., 1).90 (1758). ["America meridionalis" =type loc. subst. Surinam Berlepseh.] Laughing Hawk.

From Bolivia and Paraguay N. to Sorth Mexico.

Smaller and more richly colomed; below nearly mniform decper buff; head deeper buff; wing ô $10 \mathrm{in}$.

206a. Herpetotheres cuchinnans fulvescens Chapm., Bull. Am. Mis. N.H., xxxiv., p. 639 (1915). [Alto Bonito, R. Sucio, W. Colomb.]

IV. Colonsbia, (Pacific side of Andes),

[Not seen.]

206b. Herpetotheres cachinnans chapmani Bangs \& Mexico. Penard, Bull. M.C.Z., lxii., pp. 25- (191S). 
Gen. LTV. DRYOTRIORCHIS Shelley (1874)

Tarsus bare on lower portion; nostrils perpendicular ovals; head with a short erest of lanceolate feathers; wings short.

Length ad. 22.5 ; wing $11.9 \mathrm{in.}$; above dark brown; nape and seapulars with white bases to the feathers; quills brown, barred with darker brown, the inner webs white; tail with 6 blackish bands; below white; fawn colour on throat and chest, the former with a black central stripe ; ehest and breast with black spot on tip of each feather, becoming bars on flanks and thighs; vent and under tail-coverts with spots of rufons.

207. Dryotriorchis spectabilis speclabilis (Sehl.), Neder. Tijdschr. Dierk., i., p. 131, pl. 6 (1S63). [St. George Elmina, Gold ('oast, type in Leyd. Mus.]

Beautiful Wood-Hawk.

Wing ô $11.5 \mathrm{in.}$; chest uniform creamy white, without the large black spots (exeept in immature birds).

207a. Dryotriorchis spectabitis batesi Sharpe, Ibis, 1964, pp. 601-2. [Efulen, Cameroon, type in in Brit. Nus.]

Bates's Wood-Hawk.

W. Africa

(Gold Coast)

Gen. LV. LUTRIORCHIS Sharpe (1875).

Wings remarkably short, not extending much beyond base of tail; tail elongated; head with a short erest.

Above brown, tail with a bout 8 blackisls bars ; below white narrowly banded with black; throat and chest ashy.

208. Eutriorchis astur Sharpe, P.Z.S., 1875, p. 73, Madagasear. pl. xiii. [S. Madagascar, type in Brit. Mus.] Maclagascar Serpent-Eagle.

Cameroon,

Gaboon,

Congo

Region.

\section{Gen. LVI. CIRCAËTUS Vieill. (1816).}

Tarsus retieulated; head with a short crest as in

Dryotriorchis; wings long. 
Size large : length $931 \mathrm{in.} \mathrm{;} \mathrm{wing} 21.3$; ô 26 in.; wing 19.6.5; above dark brown, with a puplish gloss, head and wing-eoverts paler; forehead and face whitish, with lines of blaek ; seeondaries barred with darker brown and with a broad subterminal band; quills black; tail tipped with white and with 3 blaekish bands; below white, throat and chest heavily striped and flanks and abdomen barred with brown; juv. below pale carthy brown, ahdomen white, spotted and barred with brown ; tail with 4 darker bands.

209. (ircaïtus galliens (Gmel.), S.N., i., p. 2.59 (178s). [France.]

Short-toed Eagrle.

S. Enrope

$N$. to France, Germany, C. Pussia; N.E. Africa, C. Asia to N. China; India.*

Size similar ; wing $022.25-22.50$ in. : above brownish black; seeondaries and wingeoverts barred with asliy grey; npper tailcoverts tipped and barred with white; tail ashy brown with 4 blackish bands; chest blackish; throat white, streaked with blackish; below white; juv. tawny below.

210. Circaëtus pectoralis Smith, S. Afr. Q.J., Ser. I, 1830 , p. I09. [S. Africa.] Black-breasted Snake-Fagle.

Size nearly the same ; wing $\circ 22 \mathrm{in}$, ; bill much decper, upper mandible from ridge to gonys, measured through anterior cdge of nostril, $23 \mathrm{~mm}$. as against $19 \mathrm{~mm}$. in C. pectoralis; tarsi also mmeh stouter; whole under parts uniform blackish brown; immature brown below with white markings, not white with brown markings as in $C$. pectoralis.

211. Circaëtus cinereus Vieill., N.D., xxiii., p. 445 (1818). [Senegal, type in Paris Mus.]

Black-bellied Snake-Eagle.

S. Africa to to E. Tropical Africa.

E. \& W. Tropical Africa to S. Africa.

*C. hypoleucus (Pall.) must be regarded as a synonym. Apart from the fact that it was described from $\mathrm{S}$. Russia, the white bellied birds do not constitute a form. Examples from India and Africa with the white under parts are counterbalanced by examples from the same regions as dark below as typical birds. The white-bellied birds are evidently younger examples. 
Size similar ; length $q .32$ in. ; wing 20.5 in. ; ahove paler; throat and chest ashy brown, the throat varied with white bases to the feathers; below white broadly banded with ashy brown.

212. C'imeätus beandoninii Verr. et Des Murs, Tbis, 1862, p. 212. [Bissao, P’ortug. Gninea, types in Norw. \& Brit. Mhus.]

Beaudounin's Snake-Eagle.

Sinaller; length ad. 25 in. ; wing $14.6 \mathrm{in.} \mathrm{:}$ above blackish, browner on head, with pale whitish margins to all the feather's, including the wing quills, which are barred with blackish, the secondaries also with a broad subterminal hand: tail ashy brown, tipped with white, and with 4 black bands ; throat and chest fulvons brown: below white, barred with dark brown.

213. Cirenëtns fasciolatus Gray, Cat. Aeciptr. B.M., p. 18 (1848) (nom.nud.); Gmmey, Ibis, 1861, p. 130. [Natal.]

Banded Snake-Tagle.

Size similar, wing 우 16.1, ô $15 \mathrm{in}$.; above grey ; tail whitish, shaded and tipped with pale brown, and with broad blackish subterminal band and 2 narrower bands near base ; below ashy brown, shaded with grey, the abdomen and thighs barred with white.

214. Circaëtus cinerascens Mull., Naum. 1851, heft iv., p. 27. [Sennar, Egypt. Sudan.]

Cinereous Snake-Eagle.

Length 25.60 ; wing 16.20 ; tail 9.90 ; throat and chest with black shaft stripes. [Not scen.]

215. Circaëtus mufulus Reichenow, Orn. MI.B., xiii., pp. 179-80 (1905). [Songen, German E. Afr.]

Portuguese

Guinea ;

Senegambia.

Natal.

Tropical

Africa,

E. to W.

"German"

E. Africa.

Gen. LVII. PITHECOPHAGA Ogilvie Grant (1896).

Bill very deep and much compressed, ridge of culmen much curved; nostrils a vertical slit; lores and cheeks covered with bristles only; head with a crest of long lanceolate feathers; fect very powerful: tarsi mostly naked, with a row of large scutes down front; wings short and rounded; tail very long. 
Length $3.3 \mathrm{in.}$; wing 20.5 ; tail $15 \mathrm{ins.;} \mathrm{above}$ rich brown, with paler margins to the feathers, especially on head, where they are whitish buff; tail dark brown with about 4 darkel bands ; below creamy white, the thighs and flank feathers with reddish brown shaft stripes.

216. Pithecophaga jefferyi Ogilvie Grant, Bull. Philippine B.O.C., vi., p. xvii. (Dec. 30, 1896); id., Ibis, Islands. 1897, 1). 214, pl. v. [Samar, Phitipp. Is.] Philippine Monkey-Eagle.

\section{Gen. LVIII. SPILORIIS Gray (1840).}

Crest feathers of head rounded, not lanceolate; face bare witl only a few short bristles.

Length (Himalayas) 30 ; wing $19.50-21$ in.; ô (Simla, N.IT. Himalayas) length 27.50, wing $20.1 \mathrm{in}$; wings reaching beyond median pale band on tail; above purplish brown ; head and erest black with white bases; wingcoverts with small spots of white; secondaries broadly and upper tail-coverts narrowty tipped with white; tail black with a very broad median band of bromish white; throat, hind checks and ear-coverts blackish brown; below pale ochraceous brown; cllest with transverse vermiculations of dark brown; breast and belly with spots of white (bordered with dark brown), becoming bar's on thighs and under tail-coverts; nuder wing-coverts pale rufous ; onter primaries white below with terminal black band abont 4 in. wide and one median blackish band, also slight remains of a second band near base.

217. Spilormis cheela checla (Lath.), Ind. Orn,, i., p. $14(1790)$. ["India" = Luclinow, apud W. L. Sclat.]

Crested Serpent-Eagle.

Himalayas (Kashmir to Nopal); in winter to N. India.

Smaller, tarsi more slender and feet smaller; ming ô (S. India) 16 in.; (C'entr. Prov.) 17.25 in.; (Assam) 17-17.50 in. ; wing of (Assam) 17 in., (Centr. Prov.) 18.25-18.75 in. ; above darker; throat less blackish, much browner, but with blackish shaft stripes; much darker 
below; chest darker and warmer brown, uniform in oldest birds * ; white spots below similar; tail more often with median pale band nearer apical end and narrower, with remains of a sceond basal one, the terminal black band about $2 \mathrm{in}$. wide; primaries below usually showing 2 distinct black mcdian bands; the terminal one narrower and often broken; under wing-coverts rufous brown spotted with white, the greater ones ashy. 217a. Spilornis cheela albidus (Temm.), Pl. Col., i., pl. 19 (1824). [Ex Cuv., Pondicherry, type in Paris Mns.]

Lesser Serpent-Eagle.

E., C. \& S. Inclia, from

Assam to

Travancore.

Slightly smaller, and wings shouter; wing o 14.60-14.75 in.; throat and cheeks and earcoverts ashy brown; tail as in S. c. albidus; chest and upper breast always uniform darker brown in adults; primaries below with only one blackish median band.

217b. Spilornis cheela spilogaster Blyth, Jnl. As. Ceylon. Soc. Beng., xxi., p. 351 (1852). [Ceylon.] Ceylon Scrpent-Eagle.

Wing ô 17-1s in.; † 17.25-18.25 in.† larger and much paler above and below; with the hind cheeks and ear-coverts ashy; throat as pale as chest, but tinged with ashy and, like chest, finely vermiculated; white

* Vermiculated in less ofd birds, which are much lighter below; in considering this difficult group it should always be remembered that these birds certainty darken with age. Temminck doscribed albidus from a quite juvenile birch, buffish white below with streaks and spots of dark brown. The dark uniform chest is a sign of age like the single pale tail band, but the typical $S$. c. cheela is a pale race and does not usually acquire the uniform chest; although it always gets the single tail band. As we get away from the typical race these characters vary, alhidus generally getting the uniform chest, but not often being found with the purely błack tail and single band. The northern forms are the largest and the southern smallest and more variable in the characters mentioned: also often, but not always, the darkest. The moult is from the pale juvenile plumage straight into the brown ander parts with vemiculated chest and white spotted under parts, although the brown comes out in the form of bars towards the vent gradnally divirling the white interspaces first into partial bars and then rounding them off into spots. The vermiculations in some forms are lost later as the chest darkens and becomes uniform.

$\dagger$ Measurement of a skin from Shan States in coll. Brit. Mus. Burmese birds vary considerably in size, but it is impossible to place these large bircs with S. c. rutherfordi from Hainan, especially as the throat is different. 
spots below rounded and less distinct, the darker margins much paler ; primaries below as in S.c.cheele, but black terminal band not more than 3 in. wide; under wing-eoverts rufous with white spots, the outer edge white. 217e. Spilornis checla burmanicus subsp. nov. [3 Jobin, Thayetmyo, Burma, Mar. 5, 190.5, in coll. H. K. Swann, and examples in coll. Br. Mus.]

Burmese Serpent-Fagle.

Smaller ; wing (ex. from Hainan, Tring Mus.) 우 16-17 in., ô 15.50-16.25 in. ; throat slaty brown to dusky.

217d. Spilornis cheele metherfordi swinh., Ibis, 1870, p. 8.5. [Central Haiman.]

Hainan Serpent-Eagle.

Wing (ad. unsexed) 16.25-16.75; much paler above and below; wings strongly shaded with grey; sides of head slate grey; throat uniform with chest, which is pale ashy brown, slightly vermiculated; chest also sparingly spotted with white like the lower parts; tail brownish black, with brownish white median band and remains of a basal one; primaries with one black median band below, besides terminal one; under wing-coverts rufous, with white spots, outer edges white.

217e. Spilornis cheela floweri, subsp. nov. [ad. unsexed, Tahkaman, Mar. 19, 1897, and Chantaboon, July 1896, S. S. Flower, B.M. coll., Nos. 97.9.1.1 and 97.9.1.2.]

Siamese Serpent-Eagle.

"Pesembling S.c. cheela, but with npper parts somewhat paler ashy brown, with a purplish gloss, below dusty ashy ; transrerse banding on breast indistinct, often not noticeable; throat never black, but like the breast, cheeks and ear-coverts grey, not black; slightly smaller wings" [18-19.25 in.].

217f. Spilornis cheela ricketti W. Sclat., Bull. B.O.C., xl., p. 37 (1919). [ô Yamakian, Folien Prov., type in B.Al. coll.]

Chinese Serpent-Eagle.
Burma, N. to Upper Burma and Shan States, S. to Tavoy, at least, in Tenasserim.

Hainan I.; Indo China? $4: 2 \cdot 8-4255.5-$

Siam.

S. China to

Upper

Burma

(Chindwin dist.) 
Nearly as large as S. cheela cheela; length of 27 in.; wing $18.5-19$ in., tail 13 in.; darker above and below; tail with the central pale band narrower; throat and earcoverts blackish brown ; chest nearly uniform brown, but showing rermiculations in some (less old) birds; below darker and more cinnamon brown; wing-coverts darker and browner; primaries below with black areas much increased and little white.

217g. Spilornis checla hoya Swinhoe, Ibis, 1S66, Formosa. p. 304. [Formosa.]

Formosan Serpent-Eagle.

Smaller; wings reachmg to middle of pale tail band; wing (Brit. Mrss. ex.) ô 13.75-15 in. (northern largest) ㅇ 14.50-15 in. ; 오 (type Pahang) 14.60 in. ; above dark brown : wingcoverts sparingly marked with minute spots of white; secondaries not visibly tipped with white; tail with median brownish white band abont 2 in. wide and irregular narrow basal one [in oldest birds base only brownish], the 2 black bands about $1.50 \mathrm{in}$. wicle; throat and cheeks and ear-coverts slate brown *; below darker, browner and cluller than $S$. $c$. motherfordi; fore neck and chest nearly uniform with only slight traces of vermiculations: white spots on breast and abdomen broader, larger and more regular, in the form of remains of transverse bars; under wingcovert rufous brown, with very large spots of white, edge of wing white; primaries below with the median black markings concentric on inner wels instead of forming bands, the terminal black and subterminal white bands about $2.25 \mathrm{in}$. wide.

* Malacca birds usually have the subterminal tail baud whiter, throat and hind cheeks greyer, and are lighter below : chest fulvons to brown, either uniform or slightly vermiculated (less old birds). Although examples from various parts of the Malayan peninsula vary I think it best to make one race for the whole peninsula, and I have mited with it the Sumatran birds which occur not only in the lighter plumage described, but in a much clarker plumage, approaching the Javan form (s.c. bido), although a trifle smaller and with the throat paler and greyer; the tail, under wing-coverts and under surface of primaries are similar to those of S. c. bido however. Had it not been for the occurrence of this dark race in Perak and of the lighter Malay race in Sumatra it would be necessary to separate the Sumatran form. 
217h. Spilornis cheela malayensis* subsp. nov. It Malay Raub, Pahang, "alt. 4100"; June 28, 19013, Peninsula; IT. H. Craddock, in eoll. H. K. Swam ] Snmatra. [=S. bacha; auct. plur.]

Malayan Serpent-Eagle.

Slightly larger; wing 9 15.50; darker generally (elove brown); wing-eoverts heavily spotted with white, secondaries searcely tipped ; tail blaek with one broad pale meclian band, the base dark brown; throat, eheeks and ear-eoverts blackish; chest miform elove brown, without remiculations ; unrler wing-coverts usually blackish slate with white spots; white spots below irregular and only forming bars on under tail-corerts; primaries below with 2 blaek bands besides terminal one, coalescing on immer primaries, the white areas much reduced.

217i. Spilornis cheela bido Horsf., Tr. Limn. Soc., Java xiii., p. 137 (1822). [.Jara, type in Br. Mus ] Javan Serpent-Eagle.

"Resembling S. c. bido of Java, Jut with more white on underside of wing quills and the black not so well defined; a rieh number brown nape band formed by tips of black erest feathers on lower edge of crest, having conspicuous tips of that colour: tail band broader and purer white, not merely pale brown as in S. c. bido; throat quite blaek."

$217 \mathrm{k}$. Spilomis cheela kinabaluensis $\mathrm{W}$. Sclat., Bull. B.O.C., xl., p. 37 (1919). [1/t. Kinalualu, type in B.Mr.]

Borneo (Mts.

Kinabalu \& Dulit).

Smaller ; length ơ 21 in. : wing 14 in. : much paler brown above, especially on wing-coverts, but bastard wing conspicuously black; head and erest jet black ; tail black, with median band brownish white; upper wing-coverts with spots of white; under wing-eoverts rufous spotted with white; eheeks, earcoverts, chin and throat grey ; chest miform

* The name bacha cannot stand for Malayan birds. It was described from Le Vaillant who claimed it as a S. African bird erroneously and it is now impossible to say to what race it properly applies. Gurney thought Le Vaillant's plate more like the Malacean bird, but considered the name would be best discarded ? Ibis, 1878, p. 100). In any case it is predated by bassus Forster (179S), an equally cloubtful name. 
brown; primaries below with the white subterminal band about 3 in. wide; below tawny witn white spots.

2171. Spilornis cheela pallidus Walden, Ibis, 1872, 1. 363. [Sarawak.]

Bornean Serpent-Eagle.

Smaller and mueh paler (especially on wingcoverts) than S. c. pallidus; tail shorter and light band narrower; wing (Nias I.) ad. 11.612 in. ; tail 7.5 in.; (Bunguran I.) wing 우 12 iu. ; ehest miform (pale ashv brown in Bunguian I. birds and throat grey): head and bands on wings and tail black not brownish as in S. c. minimus.

217m. Spilornis cheela salvadorii Berl., Nov. Zool., ii., p. 73 (1895). [Nias 1s., eo-type in Tring Mus. j

Salvadori's Serpent-Eagle.

Larger; wing $\hat{o} 14.25 \mathrm{in}$. : similar to last form, but very pale below; much paler than S.c. pallidus of Borneo.

217n. Spilornis cheela subsp.? [ỗôTriomate, Yayeyema, S. Loo Choo Is., June 16 and 19, in coll. Tring Mus.] [=S. pallidus Ogawa, Annot. Zool. Japon., v. 4, p. $213,1905$.

Very small and pale form compared with $S$. cheela cheela, wing ô 11.50 ; O 11.75 ; head and erest (shorter) blackish brown instead of black; tail with the terminal and median bands dusky brown instead of black, the subterminal and basal bands light brown; throat and chest pale fulvous brown withont vermiculations; bands on primaries below as well as tips dusky brown instead of blaek.

217o. Spilomis cheela minimus Hume, Stray Featl., i., p. 464 (1875). [Kramorta, Nicohar Is., type in Br. Muss.]

Nieobar Serpent-Eagle.
Borneo

(low eountry, Sarawak to Sandakan).

Nias I. (W.

Sumatra); Bunguran I., (N.W. of Borneo).*

Loo Choo Is., S. of Japan.

* I have united the Punguran I. birds (Tring Mus,) with salvadorii as they agree so well in size, although a little paler, and are certainly not pallidus. There is no connecting link between these and the Nias I. birds, however. 
Larger ; wing ㅇ 15.25-16.25 in. ; throat ashy ; ehest pale ashy brown finely rermienlated; below tawny, the white spots rounded, beeoming bars on thighs; tail with the pale band, but a distinct basal one brown.

217 p. Spilornis cheela davisoni Hume, Stray Feath., i., p. 307 (1873). [S. Andaman I., ty]e in Br. Mus.]

Andaman Serpent-Eagle.

"Perhaps elosest to the Andaman raee (S. c. davisoni) but distingnished by the richness of its colonring and its breast being marked with narrow transverse bands of dusky and rufous brown - these bands often extending on to the throat" ; wing av. $15.40 \mathrm{in.}$

$217 q$. Spilornis cheela palawanensis IV. Selat., Bull. B.O.C., xl., p. 39 (1919). [ㅇ Palawan, type in B.M.]

Smaller ; length ô 19.75-21.50; wing 13$14.25 \mathrm{in.;}$ \% length 19.50-22.10 in.; wing 12.50-14.20 in.; bend of wing mottled instead of uniform white or yellowish white; tiloial plumes spotted instead of barred. [Doubtful form; not seen, and characters given quite insufficient; probably identieal with Sumatran bird.]

217r. Spilornis cheela abbotti Pichm., Pr. U.S.N. Simalur Mus., xxvi., pp. 492-3 (1903). [Simalur I.] Island, W. Abbott's Serpent-Eagle.

\section{Sumatra.}

Length ad. 22.5; wing 15.6 in.; very dark form; above and below dark elove brown; wing-eoverts and wings with minute white spots; tail with subterminal band brown and narrow; the basal one brown but indistinet; the terminal and median bunds black; below with white spots distinct, rounded, and continued up to throat.

218. Spilomis elgini* Tytler, J. As. Soe. Beng., xxxii., p. 87 (1863). [S. Andaman I.] Elgin's Scrpent-Eagle.

Andaman Is. Nicobar Is.

* The ocmurrence of this bird along with a form of $s$. chrela cheela proves it to be a good species, apart from its very distinctive coloration and markings. 
Length ô 17.6, wing 13.3 in.; head black; above purplish brown, npper tail-coverts tipped with white; wing quills with broad subterminal hand of purplish brown and banded with dark brown below ; tail tipped with white and with broad blackish subterminal band and 2 less distinct ones nearer base; faee and throat bluish ash; ehest uniform dull rufous; below rufous brown with large spots and bars of white.

219. Spitornis rufipectus rufipectus Gould, P.Z.S., 1857 , p. 222. [Macassar, type in Brit. Mus.] Celebes Serpent-Lagle.

Length, nearly ad., 18.5 ; wing 12.2 in. ; more closely banded and spotted below.

219a. Spilornis rufipectus raja Sharpe, Bull. B.O.C., i., p. lv. (1893). [Kuching, type in Brit. Mus.]

Bornean Serpent-Eagle.

Length 918 , wing $12.1 \mathrm{in.} \mathrm{;} \mathrm{ô} \mathrm{length} 17 \mathrm{in.}$; wing 12.2 in. ; rufous of ehest paler.

219b. Spilomis rufipectus sulaensis Schl., Tög. Ned. Sula Islands. Valkvög., p. 38, pl. 23 ; figs. 4-6 (1866). [Sula Is., type in Leyd. Mus.]

Sula Serpent-Eagle.

Larger ; wing $913.50-14.5 \mathrm{in}$. ; above pale brown, with a purplish gloss, the feathers irregularly spotted with white at tips ; interscapulary region with pale rufous tips and large rominded white spots; head and crest ashy black, spotted with white, and with rufous margins; tail with broad median and subterminal blackish bands; faee and throat ashy grey; rest of under parts pale tawny rufous, ocellated with spots and half bars of white.

220. Spilornis holospitus holospilus Vigors, P.Z.S., J831, p. 96. [Near Manila.] Philippine Serpent-Eagle.

ippine

Is. (Luzon, Cebu, Mindanao, Basilan.)

Wing 오 12.50 ; very mueh paler, especially below, without the rufous shade on breast and belly. 
220a. Spilornis holospilus punayensis Stecre, List Birds, ete., Philipp), p. 7 (1S90). [Panay, Philipp. Is., type in Br. Mus.]

Steere's Scrpent-Eagle.

Philippine

Is. (Panay

Guimares, Negros.)

Length ô $17.10 \mathrm{in.}$; wing $10.15 \mathrm{in.}$; tail 6.50 in. ; above drab eolour, with a slight coppery sheen; ear-coverts and checks grey; some of wing-feathers with narrow white tips and top of head and oeeipital feathers black; tail with 2 light bars; throat white with grey median stripe; breast buffy wood brown, beeoming much paler on abdomen; unspotted. [Not scen.]*

221. Spilornis hlossi Riehm., Pr. U.S.N. Mus., xxv., pp. 30t-5 (19(1) . [Gt. Nicobar I.]

Kloss's Serpent-Eagle.

Great

Nicobar:

Islancl.

\section{Gen. LIX. KAUPIFALCO BP. (1854). \\ [= Asturinula, anct. plur. $]$}

Size small; head not erested; nostrils eireular; tarsi unfeathered, transversely plated in front.

Length 우 13.5; wing 9.5 in. ; of length 12 , wing 8.9 in.; above slate grey, lighter on head; primaries blackish, tipped with white; rump black; lower upper tail-coverts white; tail black, tipped with white and with a median band of white; throat white with eentral stripe of blackish ; chest ashy grey; below white, finely barred with ishy brown.

222. Kanpifalco monogrammicus monogrammicus (Temm.), Pl. ('ol., i., pl. 314 (1S:4). [S'enegal.] One-lined Hawk.

Tropieal

Western, Central \& E. Afriea.

Smaller; wing 우 8.50; bands below mueh broader and darker, especially on the thigh feathers; white band on tail much narrower ; white of throat more extensive and dark throat stripe narrower.

* From the measurements, pale coloration, and locality this might be assumed to be an immature example of $s$. c. minimus. One other form of Spilornis, S. asturinus Meyer (S. B. Ges., Isis, Dresden, p. 13, 18st, Patr. ign.) I do not know the relations or distribution of, and so cannot place. 
222a. Kanpifalco monogrammicus meridionatis Hartl., P.Z.S., 1860, p. 109. [Ambriz, Angola, Damaraland type in Br. Mns.] to Angola on Southern One-lined Hawk. IT. anck to Nyasaland.

Gen. LX. BUTASTUR Hodgs. (1843).

[Head not crested], nostrils oval, with a superior membrane.

Length $\circ 18.5$; wing 12.2 in.; ô length 16 ; wing $11.7 \mathrm{in}$; above pale rufous brown (with darker shaft-stripes), darker on head; nape mostly white; wing-covents yaler and varied with white; tail tipped with buffy white, and with 6 or 7 nearly obsolete blackish bars, the subterninal broakest; throat yellowish white, with a line of black each side and down eentre; breast pale unfous brown with ycllowish white bars; abdomen nearly nuiform buffy white.

223. Butastur teesa (Frank!.), P.Z.S., 1831, pt. 1, 1. 115 (1832). [India, between Ganges and Nerbudda.]

White-eyed Buzzard-Hawk.

Buluchistan,

Kashmir,

Inctian

Peninsula,

Burmese

Provinces.

Size almost similar; above brownish ashy; clearer on head, hind neck and wing-coverts; quills rufous, extermally ashy grey, barred with ckark brown; tail rufous with 6 blackish bars; below ashy, with blackish shaft-stripes and a few whitish bars on tlanks.

224. Butastur liventer (Temm.), Pl. Col., i., pl. 438 (1827). [.Jave, type in L yd. Mus.] Ashy Buzzard-Hawk.

Indo-

Chinese

Provinces,

Greater

Sunda Is.,

Celebes.

Larger; wing 오 13.6; $\hat{o} 13.1 \mathrm{in.}$; above rufous brown, more ashy on head and mantle, and rufous on wings, rump and upper tailcoverts, which latter are barred and tipped with white; tail with 4 bands of blackish brow $n$; forehead and throat white, latter with mesial brown stripe; feathers of hind neck 
with white bases; below barred with white and pufous brown.

225. Butasturindicus (Gmel.), S.N., i., 1. 261 (17SS). [ex Lath.- Jara.]

Eastern Buzzand-Hawl.

Cisuri-land, Japan and E. China ; in winter to $\mathrm{S}$. China, Malay Peninsula, Philippine Is., Celebes, Borneo, ete.

lengtl ad. I6.5; wing 12.3 in.; abov cinereous bown with black shaft-stripes, and rufous margins to the feathers; head and neck darker; least wing-coverts and quills rufous; tail with 3 or 4 blackish bands, cxeept on centre feathers; throat creamy buff; below pale rufous, with narrow shaft strealss.

226. Butastur rufipennis (Sund.), (Etv. Vet. Akad. Förh. Stockh., 1850, 1). 131 (1S51). [near Khartoum, type in Stoclih. Mus.]

African Buzzard-Hawl.

N.T. Africa,

(Egypt,

Siuclan,

Abysininia,

Br. E. Africa,

"German"

E. Africa).

Gen. LXI. TERATHOPIUS Less. ('T'raité, livr. i., Febr., 1830).

$$
\text { [= Helotarsus, auct. plur.] }
$$

Head with a erest of rounded feathers; tail extremely short ; wings exceeding tip of tail by more than length of tarsis.

Length 9 25, wing 21.5, tail 5 in., ô length 21 , wing 21.2 , tail $4.5 \mathrm{in}$ : head and under parts glossy black; hind neck, mantle and tail rich maroon chestnut, lower back paler ; seapulars and quills black ; wing-eoverts palo bronze brown, whitish on shoulder: under wing-coverts white; axillaries black; bill black, feet coral red.

227. Terathopius ccaudutus Dand., Traité, ii., p. 54 (1S00). [Anteniquoi country. S. Africa.] Batalem Eagle. [T. leuconotus (Rüip].) is a synonym.]

Africa (Cap)e Colony to Egyptian Suclan and E. Africa ; Sencgal). 
Gen. LXII. HALIAËTUS Savigny (1809).

Size of, and with general charaeters of Aquila, but tarsus not feathered more than half way down; the front scutellated, sides and back reticulated; no membrane between the toes; head not crested, but feathers of neek long and lanceolate.

Length + $36-38$; wing $26 \mathrm{in.}$, o length 33 , wing $24 \mathrm{in.}$; general plumage brown, with paler greyish margins to many of the feathers above; head and neck much paler, nearly white in very old birds, with ashy brown streaks; quills black, shaded with grey externally; longer upper tail-eoverts and tail pure white; bill and feet yellow. Inmature: head and neck blackish brown; general plumage fulvous brown, mottled with dark brown; tail brown.

228. Haliceëtus albicilla (Limn.), S.N., i., p. 89 (1758). ["Europa, America"-latter errore-type loc. Sueden sugg. Harteit.]

White-tailed Eagle.

Europe, S. to

Mediterranean on E. side; Iceland, Greenland ;* Asia Minor, $\mathrm{N}$. and $\mathrm{E}$. Asia†; in winter S. to India.

Size similar ; wing 23-25 in.; head and neck all round, rump, upper tail-coverts and tail pure white. Immature; head and neek black and tail mingled white and black at first.

229. Haliceёtus lencocephatus leucocephalus (Linn.), S.N., ed. xii., i., p. 124 (1766). [ex CatesbyCarolina.]

Bald Eagle.

United

States, S. to

Lower

California \&

N. Mexico.

* The Greenland form may be separable, cf. Hartert, Vög. Pal. Fauna p. 1178 (1914) but material is lacking.

$\dagger$ Bishop records it from Alaska and Brit. Columbia: cf. Biol. Surv. U.S. Dept. Agric, xix., pp. 73-74 (1900); Auk, xxii., pp. $79-80$ (1906). 
Rather larger ; wing $025.50 ; 072.5 \mathrm{in}$.

229a. Haliceёtus lencocephalus alascanus C. H. Townsend, Proe. Biol. Soe. Wash., xi., p. 145 (1897). [Unalaska, type in U.S. Nat. Mus.]

Alaskan Bald Eagle.

Length ad. 41, wing 24.4 in. ; tail with 14 feathers; gencral plumage brown, with ashy streaks to head, neek and under parts, and whitish tips to feathers of npper parts; wingcoverts, rump, upper and under tail-coverts. tail and thighs white; immature has these latter parts only mottler with white.

230. Halicëtus pelagicus pelagicus (Pall.), Zoogr. Posso-Asiat., i., p. 343 (1827). [Islands between Kamtschatha and America: Bering Is.] Steller's Sea-Fagle.

Wing $\widehat{o} 21.62$; differs from $H$. pelagicus in the great height of its bill and also in having only the tail and upper and uncler tailcoverts pure white; rest of plumage blackish brown, the feathers on crown and neek with a fine central greyish line ; bill and feet orangevellow.

230a. Halicëtus pelagicus niger Heude, Naturaliste, 1S87, p. 95. [liorea.] [=H. branickii, Tacz.] Black Sea-Fagle.

Wing ô $24.4 \mathrm{in.}$; tail much longer (14.4 in.) and regularly graduated ; 5 primaries sharply emarginated, but distance between tips of innermost seeondaries and primaries large, 5.5. in. as against $2.5 \mathrm{in}$. in $H$. p. niger.

230b. Halicëtus pelagicus macrurus (Menzb.), Bull. B.O.C., xi., p. $4(1900)$. [Yakutsk, E. Siberia.] Long-tailed Sea-Eagle.

Smaller ; length 925 ; wing 23.2 in., ô wing $22.3 \mathrm{in.}$; entire under parts, as well as head and neck, white; above ashy grey, shaded with brownish; primaries blackish; tail black for basal two-thirds, terminal third white. Immature: whole plumage brown
N.IV. Alaska, Bering I., N.IV. Mackenzie \& N. Ungava, S. to Brit. Columbia \& Gt. Lakes.

N.E. Siberia, Kamtschatka, Sakhalin; in winter S. to Japan.

Korea, Ussuri.

Siberia. 
with whitish shaft-streaks; quills and tail barred with darker brown.

231. Malirëtus lencogaster (Gmel.), S.N., i., p. 257 (17SS). [ex Lath.- type loce sugg. N.S. Wales, Math.*]

White-bellied Sea-Eagle.

Indian

Peninsula, Indo-Chinese Provinces, S.E. China, Malay Pen. \& Arehipel., Australia, Oceania.

Larger ; length $q 33$, wing 24.4 in. ; ô length 30 , wing 22.2 in. ; above dark brown, more tawny on hind neck and sandy on head; rump purplish brown: tail white, with base and broad terminal band black; face and throat buffish white; below fulvous brown, with pale centres to chest feathers.

232. Halicëtus lencoryphus (Pall.), Reise d. Russ. Reichs., i., 1) 454 (1771). ["Iaiknm in Australioribus" = Lower Ural River, apud. W. L. Selat.]

Pallas's Sea-Eagle.

Smaller; length ㅇ 2.5; wing $20.5 \mathrm{in.;} \hat{o}$ length 22 ; wing $19.2 \mathrm{in}$.; head, neek, breast, interseapulary region and tail pure white; least wing-coverts rufons; primaries black; rest of upper surface blackish brown, and of lower surface deep chestmut.

233. Haliä̈tus vocifer (Daud.), Traité, ii., p. 65 (1800). [ex Levaill.-Keurboom R., Cape Col.] Vociferous Sea-Eagle.

Size similar'; general plumage blackish brown; tail buffy white; feathers of head, hind neck and throat with buffy margins: cheeks and sides of neck white; chest and under parts like upper parts, but with rufous stripes on ehest.

234. Halinëtus rociferoides Des Murs, Rev. Zool., Madagasear. 1845, p. 175. [Hadegascar, type in B.A.] Madagascar Sca-Eagle.

* No locality given by Latham, but stated to have been brought in " one of the last circumnavigating ships."
S.E. Pusssia, Asia Minor, Caspian, \& Central Asia to Mongolia ; India, Burma.

\section{Tropical}

Africa, S. to Cape Colony. 
Gen. LXI1T. GYPOHIERAX Riipp. (18.55).

Space above and around eye hare, as well as a line on either side of throat; front of tarsus reticulated ; claws with a groove below as in Haliceetus; head slightly crested.

Length ô $23 \mathrm{in.;}$ wing $17.2 \mathrm{in.;}$ general phmmage white; seapulars and secondaries black; primaries white with the tips blark and onter webs mottled with black; tail black with hroad terminal band of white; bare skin of face and feet flesh colour; cere bhuish grey.

235. Gypokiera. angolensis (Cmel.), S.N., i., p. 2.2 (1788). [Angola.] Angola Vulture.

Tropical

IV. Afriea, Angola to Senegambia ; E. Afriea.

Gen. LxIV. HALIASTUR Selby (1S40).

Nostrils eireular, with bony margin all round; presents affinities both with Aquilina and Hilvince.

Length ad. 20, wing $15-15.50$ in. reaching beyond end of tail*; tail 7.50-8 in.; head, neek, throat and breast white with distinet blackish brown shaft-stripes, narrowest and blackest in old birds; rest of plumage maroon ehestnut, paler on tail, which is whitish at tip: primaries brownish black; bill yellowish, the base blackish; feet light greenish yellow.

236. Haliastur indus indus (Bodd.). Tabl. Pl. Indian Enlum., 1).25(1783). [ex Buff.-Pourlicherry.] Peninsula, Brahminy Kite.

Ceylon, Bumese

Provinces ; S. China.

Wing o $16 \mathrm{in}$. ; reaching nearly 2 in. beyond end of tail; tail 8.50 in.; the black shaftstreaks on head, hind neek and breast rednecd to hair-lines and much less distinet.

* Ceylon birrls seem to have as a rule slightly shorter wings and longer tail than Indian birds, and to have the wings as a rule falling well short of end of tail. 
236a. Haliastur indus intermedius Gurney, Ibis, Indo-Chinese 1865, p. 28. [Java.]

Malay Brahminy Kite.

Provinces,

Nalay Pen.,

Java,

Sumatra,

Borneo,

Philippine

Is., Celebes :

Babber I.

Sizesimilar ; wing ô 14.2 ; ㅇ 15.3 in. ; head, neck, interscapulary region and throat and breast snowy white without any sign of black streaks; rest of plumage bright maroon; tail with a broad terminal bar of white ; eere and bill pale yellow, latter darker at tip and bluish at base; feet whitish yellow.

236b. Haliastur indus leucostermus (Gonld), P.Z.S., 1837, p. 138. [Australia=Moreton Bay, Queensl., apud Math., type in Philad. Acad.] White-lieaded "Sea-Eagle."

$[=H . i$.girrenera (Vieill. et Ond.)]

Pather larger, length ad. 22 ; wing 16.6 in. ; above ashy brown, more rufous on head and clarker and more chocolate on seapular's and wing-coverts; primaries bromlish black; tail greyish-brown, paler at tip, and at base of outer feathers; throat fulvous ; breast dull ochraceous, the feathers bordered with brown and streaked with white; flanks with black shaft-streaks; cere and bill greyish; feet bluish white.

237. Haliastur sphemurus sphenurus (Vieill.), N. Dict. d'Hist. Nat., xx., p. 564 (1818). ["Australia" = N.S. Wales, apud Math., type in Paris Mus.]

Whistling Eagle.

"Lighter and smaller" (Math.) ; "of a much lighter colour, especially on the upper portion of the head, neek and seapular's" (North). 237a. Haliastur sphenurus sarasini Math., Bols. Austral., v., p. 169 (1916). [New Caledonia.] New Caledonian Whistling Eagle.

Sub-Fam. VI. MILYINA.

Head usually closely feathered; loral bristles seanty or wanting; cere contracted ; nostrils oval,

Australia, New Guinea, Molneeas, Tenimber, Ceran, Aru Is.

Anstralia.

New

Caledonia. 
oblique, generally elosed in with a superior membrane; bill usually rather weak, straight at base, curved from cere to point, the eutting edge at most slightly festooned, but in two or three genera either toothed or serrated; wings usually long, more or less pointed; tail variable; feet small and weak; tarsi feathered for a variable distance.

Gen. LXV. ELANOIDES Vieill. (1S18).

Tail very long and deeply forked, onter feather much the longest; wings very long and pointed, but not reaching beyond next outermost pair of tail-feathers.

Head, neek all round, rump and entire under parts snowy white; back, wings and tail glossy black with purplish and green reflections, the former especially on the scapulars and wings; secondaries white on inner webs, except at tips.

238. Elanoides forficatus forficatus (Linn.), S.N., i., p. 89 (1758). ["America" ex Catesby $=$ Carolina.]

Swallow-tailed Kite

N. America, (breeds in S. United States, but winters $\mathrm{S}$. of them) ;

Mexico.

Wing of (Venez.) 16.60) outer tail-feathers 12.75 in. "Differs from N. Ameriean specimens in havmg [reflections on] the seapulars and to a lesser extent interscapulars rich bottle green instead of dark purplish maroon" (Chapman). [Doubtfully distinct.]

23Sa. Elanoides forficatus yetapa Bonn. et Vieill., Eney. Meth., iii., p. 1205(1823). [Paraguay.] Southern Swallow-tailed Kite.

C. America (Costa Riea) S. to Pern, Bolivia \& Paraguay.

Gen. LXVI. NAUCLERUS Vig. (1825).

Tail much shorter; wings long. but not greatly exceeding length of tail. 
Length 14.5; wing 9.95; tail 7.8 in.; above cinereous, darker on interseapulary region; wing and tail quills ashy grey, the seeondaries white at tips ; forehead and indistinct eycbrow whitish; cheeks and under pasts pure white.

239. Nauclerus riocouri (Vicill. et Ond.), Gal. Ois.. i., p. 43, pl. 16 (1823). [Sencgal, type in Br. Mrus.]

Cinereous Kite.

N.E. Africa ; IV. Africe (Senegambia to Hausaland).

Gen. IXVII. MIINUS Iacep. (I799).

Tail forked, but difference between longest and shortest feather less than differenee between tips of primaries and tips of secondaries.

Length ad. about 24 in., wing $19-20.75$; tail 14-15 in.; plumage above brown with rufous margins, the wing-eoverts paler; primaries black ; rmmp dark brown ; upper tail-coverts rufous; tail rufous, tipped with fulvous, the outer feathers partly barred with dark brown on inner webs; head, face and throat whitish streaked with dark brown ; chest pale rufous, with dark central streaks and paler edges; below bright rufous, with dark central streaks; bill hom colour; cere and feet yellow.

240. Milvus milous milvus (Limn.), S.N., i., p. S9 Eirope, (1758). [Europe, Asia, Africa-type loc. S. breeding Sweden, apud Hartert.]

Common Kite.

from S.

Sweden S. to Spain, also Mloroceo, Asia Minor, Canary Is ; in Brit. Is. confined to Wiales.

Wing ad. 18.20-19.30; tail less forked, depth of fork only about half as great; all the feathers, including central pair, barred.

240a. Milvus milvus fasciicauda Hart., Bull. B.O.C., Cape Verd Is. p. 89 (1914). [ô Santo Antao, Cape Verd, (resident). in Tring Mus.] Cape Verch Kite. 
Length of (Caucasus) 24, wing 18.5; tail $10.5 \mathrm{in.}$; above dark brown, much paler and greyer on head and hind neck and throat, which are much streaked with dark brown; tail with very indistinct darker bars; below dull rnfous brown, brighter on abdomen, with blackish shaft-lines: cere orange, bill black, feet yellow.

241. Milvus migrans migrans* (Bodll.), Tabl. Pl. Enl., p. 28 (1783). [ex Diub., pl. 472, Buffon ete., type loe. France, amud Hart.] Black Kite.

E., C. \& S. Gurope, N. to Finland, $\mathrm{S}$. to Mediterranean and N.W. Africa ; Asia Minor, C. Asia ; in winter to Tropical Africa ; cas. Brit. Is.

Size nearly the same; tail more rufous brown, with 7 or 8 more distinet blackish bands; head and hind neck browner; car-coverts darker ; below rather more rufous, especially on abdomen, thighs and under wing- and tail-coverts; bill, as well as eere and feet, bright yellow.

24la. Milvus migrans regyptius (Gmel.), S.N., i., p. 261 (1.78s). [Egypt.]

Yellow-billed Kite.

N. \& E.

Africa,

Palestine,

Arabia; cas.

in S.E.

Europe.

Slightly smaller; wing 17 in.; less rufons, more cinnamon-brown below; bill yellow.

241 b. Milvus migrans parasitus Daud., Traité, ii., p. $150(1800)$. [Ex Levaill. South Africa.] Parasitic Kite.

Africa, S. of

Sahara to Cape Colony ; Madagasear \& ('omoro Is.

Length $\hat{\text { A }} 20$; wing $19 \mathrm{in}$; head and hind neck slightly rufescent, with distinet ecntral stripes of black; scapnlar's and wing-coverts

* Gmelin's name korschum (1771) should never have boen used for this bird: it does not seem to have been a form of Milvus ho described at all. 
edged with buff ; tail distinctly barred with blackish; below dull rufous brown; the breast feathers with pale fulvons stripes next the dark shaft-streaks; vent and under tail-coverts more buffish ; cere and feet yellow, bill blackish.

241c. Milvus migrans govinda Sykes, P.Z.S., 1832, p. 81. [Deccan, type in Brit. Mus.] Indian Kite.

India ;

Ceylon ;

Burma;

Russian

Turkestan.

Rather smaller; wing 16.5 in.; above blackish brown, paler on wing-coverts, with blackish shaft-stripes ; tail dark brown, with remains of dark bars on centre feathers; head and hind neek pale brown, washed with rufons and with blackish shaft-streaks; below dull rufous brown, more dusky on chest and flanks, with distinct black shaft-streaks; cere and feet yellow, bill blackish.

241d. Mitvus migrans affinis Gould, P.Z.S., 1837, Australia, p. 140 (1838). [Australia $=$ New S. Wales, Celebes, apud. Math.]

Allicd Kite.

Larger, length 025.5 ; wing 21 ; tail 13.2 in. ; above dark chocolate brown; head, hind neck and wing-coverts more rufons and with black shaft-streaks; tail paler brown, more rufous on central feathers and distinetly barred with darker brown; lores, foreh ad and eheeks white with black shaft-lines; earcoverts brownish black; below deep rufous brown, clearer on abdomen, with broad black central stripes, especially on chest; cere and feet greenish yellow; bill black.

242. Mitvus lineatus (Gray) in Hardw., Ill. Ind. Zool., i., p. 1, pl. 18 (1832). [China.] $[=M$. melanotis, anct. plur.]

Black-eared Kite.

Lesser Sunda Is.

Japan, N. China, Mongolia, to Cent. Asia \& Himalayas, IV. to Ural ; in winter $\mathrm{S}$. to Burma, N. India \& Hainan. 


\section{Gen. LXVIII. LOPHOICTINIA Kaup (1847).}

Heat erested ; bill moderate, the tip not prolonged ; tail even.

Length 19; wing 18 in.; above blackish brown, wing-eoverts paler and slightly rufous with dark centres; wing quills and tail dark brown, externally greyish, banded with black, the subterminal band very broad; head dull rufous, and forchead, checks and throat whitish, with black centre streaks; ear-foverts grey ; below rufous ; chest with broad black eentres to all the feathers, becoming narrow shaft-streaks below; cere and feet greyish white; tip of bill blackish.

243. Lophoictinia isure (Gould), Nyn. Bds. Austr., Australia, pt.iii., pl. 47 (1838). [New s'. Wules.] E. \& W. Square-tailed Kite.

\section{Gen. LAIX. RostrhHAIU's Less. (1830).}

Heat not crested; bill very long and slender, the upper mandible hooked almost into a siekle-shape, the cutting edges not festooned; nostrils narrow ovals, horizontal; tail about half as long as wing, nearly even.

Length ad. 13.5; wing 11.7 in.; general colour lead grey, the wings blackish; tail grey with a broad terminal band of black; eere, lores, gave and feet orange yellow ; bill black ; iris reel.

244. Rostrhamus sociabilis (Vieill.), N.D., xriii., p. 318 (1817). [s. America: Corrientes et Rio de la Plata.]

Everglade Kite.

S. Ameriea

from

Argentina

and Peru to

Colombia ;

Central

Ameriea,

E. Hexico ;

Cuba aud

Florida.

Larger and blacker; length ad. 1s; wing $14.1 \mathrm{in}$. ; entirely slaty black, with a bromnish shade on wings ; base of tail and upper and under coverts white ; tail black, tipjed with white, with a subterminal bar of ashy brown; bill black; eere and feet yellow. 
245. Rostrhamus hamatus 'Temm., Pl. Col., i., pl. N. Brazil, 61, 231 (1823). [Brazil.] $[=R$. leucopygus Guiana? (Spix) of Sharpe.] Colombia ? Slender-billed Kite.

\section{Gen. LXX. PEGERHINUS Kaup (1845). \\ [=Leptodon, Sudev. of Sharpe.]}

Tail rounded, outer feather shorter than middle one ; loral space bare; upper mandible without a tooth.

Length ad. ㅇ 17 ; wing 11.7 ; tail 7.5. in. ; above and below blnish slate, with narrow irregular bars of white below; primaries blackish shaded with slate grey; secondaries whitish below, barred and tipped with black; tail ashy grey with 2 bands of black; under tail-eoverts buff; bill black. First mature plumage generally browner, with a rufous collar round hind neck; below banded with tawny rufous and ochraceous buff.

246. Regerhinus uncinatus uncinatus (Temm.), Pl. Col., i., pl. 103-5 (1824). [Brazil=Rio Janeiro, apud Chubb, type in Leyd. Mus.] Hook-billed Kite.

Larger (wing 0 12.6) and with a larger bill (culmen $2-2.5$ in. against $1.55-1.65$ in. in typical form).

246a. Regerhinus uncinatus megarhynchus (Des Murs), in Casteln., Voy., Ois., p. 9, pl. i. (1855). [Sarayacu, type in Paris Mus.] Large-billed Kite.

Wing ad. 9.70-10.50 in.; tail black with 4 light bands, the 2 anterior ones white, other's light ash grey; below white, barred with pale grey anteriorly and umber posteriorly (Ridgway).

246b. Regerhinus uncinatus wilsoni (Cass.), Jnl. Cuba. Acad. Philad., i., p. 21, pl. 7 (1847). [Cuba.] Wilson's Kite.

Gen. LXXI. LEPTODON Sundev. (1535).

The upper mandible with a single more or less pronounced tooth. 
Length + 21)-22 in.; wing $12.25-13.25 \mathrm{in}$; above glossy blaek; head slaty grey; wing quills black, banded with slate grey; tail black with 3 bands of asliy grey and tipped with same; below white; bill blackish; feet yellow.

247. Leptodon palliatus (Temm.), Pl. Col., i., pl. Brazil, Peru, 204 (1823). [Brazil, type in Brit. Mus.] Guiana to [=L.cayennensis, anct. plur.] Cayeme Kite.

\section{Gen. LXXII. GYPOICTINIA Kaup (1847.}

Bill not toothed; head crested; loral space feathered ; wings reaching to end of tail ; greater part of tarsus bare in front.

Length 24: wing 19; tail 8.5 in.; general plumage above and below blackish, browner on scapulars and more rufoms on rump ; crest and nape tawny rufous with black centres to the feathers: thighs and under tail-coverts rufons, with black shaft-lines; tail ashy grey above, whitish near base and below ; lesser wing-coverts and sccondaries margined with ashy grey; primaries ashy white at base.

248. Gypoictinia melanosterna melanosterna (Gould), P.Z.S., 1840, p. 162 (1S41). [N.S. IFales, type in Mus. Philad. Acad.]

Blackbreasted Buzzard.

"Differs from G. m. melanosterna in lacking the black on head and breast."

248a. Gypoictinia melanosterna decepta Math., Nov. Zool., xviii., 1. 250 (1912). [Pury's ('reek, N.H. Australia.]

Northern Buzzard.

Interior of N.S. Wales, S. Australia.

IV. Australia, Northern Territory.

Gen. LXXIII. ELANU'S Savigny (1809).

Tarsus feathered for nearly two-thirds of its length in front; claws without groove on under surface.

Sexes nearly similar in size; length ad. about 13 ; wing $10.15-11.20$; tail 5.16 in. ; above ashy grey', lighter on head; forchead, eyebrow, and face white; feather's round eye black; 
lesser and median wing-eoverts and a patch on onter edge of wing black ; tail whitish, the 2 centre feathers ashy grey; below silky white; sides of breast pale silvery grey, wing quills dark or blackish slate below; cere and feet yellow; bill blackish ; iris carmine. Immature browner above and streaked with rufous on chest and flanks.

249. Elanus caruleus cceruleus (Desf.) Mém. Acad. R. des Sciences, 1787, p. 503, pl. xv. (1789). [near Algiers.]

Black-winged Kite.

Africa N. to

Mediter-

ranean ;

Palestine,

S.W. Asia, India, Ceylon*;

Burma; cas. in S. Europe.

Slightly larger; wing 11.60-12; tail $6 \mathrm{in.} \mathrm{;} \widehat{o}$ wing $11.75 \mathrm{in}$.; above ashy grey ; primaries slate; wing-coverts black, the shoulder white on edge; black patch on outer edge of wing nearly absent; 2 centre tail-feathers paler grey, rest white; fore-part of headand entire under parts silky white, including under wingcoverts; wing quills white on basal half below. Immature: head and nape white, streaked with brown; above browner, with white margins to all the feathers, including wingcoverts and quills.

249a. Elanus caruleus hypolencus Gould, P.Z.S., 1550, p. 127. [Hacassar, type in Norwieh Mus.]

White-breasted Kite.

Philippine

Is., Java, Borneo, Celebes.

Size similar ; wing ad. 11.50-12.30 in. ; tail 5.75-6.30 in.; above paler, more silvery grey; tail whitish ; primaries darker below, nearly blackish; outer under wing-coverts black, forming a conspicuous patch below; axillaries white.

250. Elanus axillaris axillaris Lath., Ind. Orn. Suppl., i., p. ix. (1S01). [New S. Wales.] Black-shouldered Kite.

* Ceylon birds have the smallest wing measurement and the primaries are darkest below, right to the base of the feathers. 
"Differs from E. a. axillaris in heing lighter above."

250a. Elanns axillaris parmi Math., Nov. Zool., xviii., p. 251 (1912). [Parry's ('reek, N.H'. Anstralia.]

Western Black-shouldercel Kite.

Rather larger, with longer tail; wing 1213.30 ; tail 6.4-7.4 in. : ahove darker bluish ash, inner wels of secondaries paler, nearly white; back shoulder patch above variable, but not generally so large: black pateh below smaller usually and confined to the onter greater under wing-eorerts.

250h. Elanns axillaris lencums (Vieill.), N.D., xx., p. 563 [етr. 560] (1818). [Paraguay.]

White-tailed Kite.

\section{Whole of}

S. America,

Sonthern

United

States.

Size similar ; wing 11 ., in. ; ahove paler, ashy white, with the black patches on wing-coverts and edge of wing; axillaries as well as under wing-coverts black, except bend of wing which is white.

251. Elanus scriptus Gould, P.Z.S., 1842, p. S0. [S. A ustralia.]

Letter-winged Kite.

N.S. Wales,

Victoria,

S. Australia.

\section{Gen. LXXIV. GAMPSONTX Vigors (1825).}

Wings falling nearly an inch short of end of tail ; tail feathers rounded, nearly even; tarsus short, feathered about half way down in front.

Size small, length ${ }^{t} S$; wing 5.8 ; tail 3.9 in. ; O wing 6.15 in.; above leaden black with a brownish shade on back ; secondaries broadly tipped with white; tail below mueh paler; forehead and sides of face orange buff ; sides of neck and a collar encireling latter white, below which is an interseapulary patch of vinons red; below white, with small patch of black on each side of upper breast; the thighs pale buffish rufous, as also inner nuder wing-coverts, but not breast or flanks.

252. Gampsonyx suainsoni surcinsoni Vigors, Zool.Jnl., ii., p. 69. (1825). [near Bahia.] Paraguay. Swainson's Pearl-Krite. 
Size nearly similar ; wing $\hat{0}$ (Merida) 6 ; tail $3.75 \mathrm{in.}$; 옹 wing 6.20 ; tail 4 in.; wing 0 (Gniana) 5.90-6; 우 wing 6.20-6.40 in.; below with the sides of breast and flanks chestmut rufous [pure white in Bahia birds]; thighs darker rufous in Venezuelan birds [but hardly more so in Guianan birds] ; forehead and sides of face slightly yellower and paler.

252a. Gampsonyx swainsoni meridensis subsp. nov. [o Nevada, Merida, Nov. 15, 1903, alt. 3,000 metres, in coll. H. K. Swam and Merida and Guiana examples in Tring Mus. and Brit. Mus.]

Northern Pearl Kite.

"Upper surface darker and more strongly shaded with slaty grey; forehead and sides of face straw colour instead of orange buff " ; total length 9.10 in.; wing 6.20 ; tail 3.75 in. ; [sides of breast and flanks mfous.]

252b. Gampsonyx sicainsoni leonce Chubb, Bull. B.O.C., xxxix., p. 22 (1918). [Leon, Nicaragua, W. B. Richardson, Dee. 1892, type in Br. Mins.]

Nicaraguan Pearl Kite.

Largest ; " liffering from G. s. suainsoni only in the larger wing and tail measurements" ; o total length 9.65; wing 6.95 ; tail 4 in.; o wing $6.9 \mathrm{in.}$ [Differs from $G$. s. swainsoni also in having sides of breast and flanks rufous.]

252e. Gampsonyx swainsoni magnus Chubb, Bull. IV. Peru B.O.C., xxxix., p. 21 (1918). [Amotape, Peru, and WV. July 22, 1899, P. O. Simons, type in Br. Mus.] Eenador ; Western Pearl Kite.

Venezuela

(S. to

Orinoeo*),

British

Guiana.

Nicaragna.

\section{Gen. LXXV. ICTINTA Vieill. (1816).}

Upper mandible with the cutting edge lobed, but without a true tooth; bill short and deep, and

* Examples from the Orinoco are more or less intermediate. Of those in Tring Mus. two have the sides strongly rufous, others only slightly.

+ An example in Tring Musenm from Prov. of Sara, Bolivia, ơ has wing measurement of $6.65 \mathrm{in}$. and presmmably belongs to this form: another, $f$, from Calama River, Rio Madeira, has the wing 6.50 and is intermediate. 
strongly arched, resembling that of Falco; cere short; tail square; wings reaching about $1.25 \mathrm{in}$. beyond end of tail.

Size small ; wing ad. 11.5-12.5; tail 6 in. ; above leaden black; wings and tail blacker; head lighter grey, nape a little darker; primaries pale chestnut on inner webs, conspicuous below; under parts slate grey; tail with 3 bars of white on inmer webs below, the basal one concealed and sometimes wanting.

253. Ictinia plumbea (Gmel.), S.N., i., p. 283 (1788). [ex Lath.-Cayenne.]

Plumbeous Kite.

Size similar ; wing $\hat{o} 10.5-11.5$; ㅇ $11-12.5$ in.; above leaden black, paler on secondaries and blacker on primaries and tail, but latter without white bars below; head, neek and under parts clear grey; base of primaries chestnut on inner webs; bill black, feet orange red.

254. Ictinia mississippiensis (Wils.) Amer. Orn., iii., p. 80, pl. 25, fig. I (1811). [Natchez, Mississippi.]

Mississippi Kite.

Central and

S. Amer. to

Brazil and

Paragnay.

Southern

United

States ;

S. in winter

to Mexico

and cas.

Gnatemala.

Gen. LXXVI. HARPAGUS Vigors (1824).

Head not erested; nostrils oval with eentral tuberele; bill with 2 distinet teeth; tarsus slender with broad transverse scales; fect small and weak; wings very shott, hardly reaching to middle of tail ; size small.

Wing ad. 8.1 ; tail 6 in.; above slaty grey, head darker and wings browner; tail dark brown, with narrow bands of greyish white; below pale grey, the throat and under tailcoverts white; thighs bright ferruginous.

25.5. Harpagus diodon (Temm.), Pl. Col., i., pl. 198, 1824. [Brrtzit.]

Red-thighed Hawk.

South

Brazil (Rio

Grande do

Sul to Bahia). 
Size similar; above [oldest dress] much darker, slaty black; tail with 2 bromnish white bands; throat white, with median black streak; upper ehest greyish, below banded with grey and white; less old birds have tail browner, with 3 narrow whitish bands and another aeross upper tail-coverts; below chestmut rufous, irregularly barred, except on ehest, with whitish and indistinct darker bars.

256. Harpagus bidentalus bidentams (Lath.), Ind. Orn., i., p. 38, 1790. [Cayenne.]

Donble-toothed Hawk.

Size slightly larger, wing ad. 8.8 in.; above browner; below banded as in less old stage of last form.

256a. Harpagus bidentatus fasciatus Lawr., Pr. Phil. Acad., 1868, p. 429. [Guatemala.]

Perm,

Guiana,

Venezuela,

Colombia.

Central

America

(Guatemala,

to Panama).

Gen. LXXVII. BAZA Hodgs. (1 $\$ 36$ ).

Size moderate, length under $20 \mathrm{in}$; head with occipital erest; bill with 2 teeth (sometimes appearing as serrations); nostrils linear ovals, without tubercles; wings reaching to or beyond end of tail.

Wing ad. 9.50-9.85; tail 5.7 in. ; crest long; above glossy greenish black, browner on sides of head and throat; secondaries white, except at edges and tips, chestnut subterminally [except in very old birds]; chest white, followed by a band of black across upper breast, more or less mixed with chestnut; lower breast and flanks ereamy white, banded with chestnut; vent, thighs and moler wing-and tail-coverts greenish black. Immature: much more chestnut in secondaries and less barred below.

257. Baza lophotes (Temm.), Pl. Col., i., pl. 10 (1824). [Pondicherry.]

Crested Cuckoo-Faleon.

India (subHimalayan dist. to ('eylon); Tenasserim ; Indo-China ; Malay Pen. 
Larger; wing $\hat{\jmath} 12.5$, tail 8 in. ; 9 wing 13 , tail y in, ; general colour hrown, darker on mantle, most of the feathers with paler margins, those of head with rufous margins and white bases; erest dark brown; primaries ashy brown, banded with darker brown ; tail ashy grey with 3 bands of dark brown : throat with median and moustachial blackish stripes: below white, npper breast and sides longitudmally marked with rufous brown, lower flanks alnost uniform.

258. Baza madagascariensis (Nmith), S. Afr. Q. Marlagascar. .Jnl., ii., p. 285 (I835). [Malagascar.]

Madagasear Cuckoo-Faleon.

Smaller; wing ad. $11.6 \mathrm{in.}$; above ashy brom ; head, crest and interseapulary region darker, inclining to slaty black; quills brown above and ashy white below, barred with dark brown on inner webs, the subterminal band broad; upper tail-coverts tipped and barred with white; tail ashy grey, tipped with white, with broad subterminal and 3 other bands of black ; throat and chest clear grey; below buffy white, barred with tawny rufous ; under wing-coverts nuiform tawny rufous.

259. Baza ruculoides cuculoides (Swains.), Bds. IV. Africa W. Africa, i., p. 104, pl. 1 (!8:37). [" W. (Senegal to Africa" = Senegral?, type in (amb. Mus.] Cold Coast). IV. African Cuckoo-Falcon.

Wuch darker above, uniform slaty black; throat and chest pale grey, the barrings below confined to upper breast and of a much darker brown colour; belly, Hanks, thighs and under tail-coverts pure white, with little trace of buff ; under wing-coverts uniform rusty rufous.

2592. Baza cuculoides batesi, subs]). nov. [ô River IV. Africa Ja, Cameroon, coll. G. L. Bates, Feb. 5, (Cameroon 1907. Isit. Mfus. Reg., No. 1911. 5.31.60.] to Aruwhimi

P., Upper

Congo).

[Not secm.]

2.59b. Baza cuculoides emini Reichenow, J.f.O., Equatorial 1594, p. 163. [Albert Nyanza.]

Africa. 
Slightly larger; wing of 12.7 in.; above rather dark ashy grey, shaded with brown; crown and erest blacker ; upper tail-coverts ashy grey with brown tips; under wingcoverts barred with palc rufous and fulvous; fo browner above and more strongly barred below

259e. Baza cuculoides verreauxi (Lafr.), Rev. Zool., 1846, p. 130. [Port Natal.]

Verreaux's Cuckoo-Falcon.

S.E. Africa

(Natal to

Zambesi).

Wing ô 12.75 , ㅇ 13.10 in. ; culmen 1.4 in. ; crown and nape pale fulvous, with blackish central streaks: nape nore tinged with rufous ; erest long, black tipped with white; throat white with distinct central streak of black; foreneck and chest streaked with pale rufous; below white, with broad bands of pale rufous; oldest birds very much darker above and below, the bars below rufous brown, age apparently accounting for the light and dark forms of this species.

260. Baza jerdoni jerdoni (Blyth), Jnl. As. Soc. Beng., xi., p. 464 (1842). [Halacea, type in Mus. As. Soe. Beng.]

Jerdon's Cuckoo-Falcon.

Slightly smaller; wing ad. 11.7 in.; crown black, edged with rufous; crest black, tipjocd with white ; chin and throat buff with broad mesial black streak; chest tawny einereous, with brownish shaft streaks; below white irregularly banded with pale rufous.

260a. Baza jerdoni ceylonensis Legge, Stray Feath., iv., p. 247 (1876). [Natab, Ceylon.]

Ceylon Cuckoo-Falcon.

Wing ô 11.5 ; culmen 1.05 in. ; "sides of face and neck dull rufous; chest white, the feathers edged with rufons and with triangular black centres; under wing-coverts rufous with paler edges; :ufous bars on flanks broader and inclining to dark brown."

260b. Baza jerdoni borneensis Sharpe, Ibis, I893, p. 557. [Baran dist., Borneo, type in Sarawak Mus.]

Bornean Cuckoo-Falcon.

E. Himalayas

(Sikkım);

Burmese

countries;

Malay Pen.,

Sumatra.

Ceylon ;

S. India

(Wynaad cas.).

Borneo 
Wing ad. 12.3, bill stouter, culmen $1.5 \mathrm{in.}$; above purplish brown; crown and crest black; throat and chest grey, former with broad black central stripe; below white, banded with pale rufours; sides of face . greyish, washed with rufous.

260e. Baza jerdoni magnirostris (Gray), Cat. Accip. B.M., p. 19 (1844, nom. nud.), (Kamp), Lsis, 1847, p.343. [ex Gray, Manila.]

Philippine Cnekoo-Faleon.

Wing ad.11-12 in.; culmen $1.25 \mathrm{in}$; above darker brown; ear-coverts dark cinereous instead of grey ; chest rufous ; below banded with darker rufous brown.

26al. Baza jerdoni erythrothorax Sharpe, P.Z.S., 1873, 1. 695 (June 1573). [Celcbes.]

Pufous-chested Cuckoo-Faleon.

Smaller; wing (imm. o) 10.8 in.; below white without median black line on throat; breast and abdomen washed with ereamy buff, sides and flanks with slight spots of pale tawny buff.

260e. Baza jerdoni lencopias Sharpe, Ibis, 188s, p, 195. [Palawan 1.]

Wing ô 12.8.5-12.95: ᄋ 13.15-13.60 in.; above brown, slaty black on wings; head, ncek and chest ashy grey; with small occipital crest black; tail ashy brown, with broad subterminal and 3 other black bands; breast buffy white, banded with ehestnut brown [blaekish in oldest birds] ; thighs and under wing and tail-coverts buffy rufous.

261. Baza subcristata subcristate (Gould), Svn. Bds. Austral., pt. iii., pl. 46 (183s). [News'. Hales.

Australian Cuckoo-Falcon.

Smaller; wing ô 11.65-12.10; † 12.5-12.85 in.

261 a. Baza subcristata timorlaocnsis Mever, Abhandl. Ber. Zool. Mus. Dreseden, 1892-3. No. 3, p. 5 (1893). [Timorlant.]

Tenimber Gnekon-Faleon.
Plrilippine Is.

Celebes; Sula ls.

Palawan

Island (Philippines).

Austrablia (N.S. Wales, Queensland); S.E. New Guinea.

Tenimber Island. 
Seareely smaller; wing ô $11.30-11.65$; 우 11.85-12.35 in.; fore neck and chest very pale grey; bands on under parts narrower, as also those on under surface of quills.

261b. Baza subcristata pallirla Stresemann, Nov. Kei and Zool., xx., ]. 307 (1913). [ô Tual, Kei Is., Goram Is. Kühn coll., Tring Mrss.]

Wing ơ $11.25-11.90$, $911.25-12.10 \mathrm{in}$; head, neck all round, interseapulary region and chest ashy grey; crest blackish ; seapulars and immer secondaries chocolate brown; breast and flanks buffy white, with blackish brown erossbars; vent, under tail-coverts and under wing-eoverts orange buff.

261e. Baza subcristata reinwardi (Müll. \& Sehl.), Moluccas Naturl. Versch., Av., p. 35, tab. 5 (1843). (Ceram, ["Celebes, Borneo," errore-type loc. subst. Amboina, Stresemann: Amboina.] Reinwardt's Cnckoo-Faleon.

Bonru, Aru Is. Tisol) ;

New Guinea.

[Said to be larger.]

261d, Baza subcristata megala Stresem., Nov. Zool., Fergusson 1.* זx., p. 307 (1915). [Fergusson I., D'Entrecasteaux Archip.]

Size almost the same; under wing-eoverts paler isabelline colour .

261e. Baza subcristata gurncyi Ramsay, Jnl. Limn. Solomon Soc. Zool., xvi., ]. 130 (1881). [Solomon Is.] Islands. Solomon Islands Cuckoo-Falcon.

Slightly larger; wing ô 12.25-12.35; ㅇ 12.50$13.05 \mathrm{in}$.

261f. Baza suberistata bismarcki Sharpe, in Gonld's Bds. New Guinea, i., pl. 4 (188s). [Bismarck Archip.]

Bismarek's Cuckoo-Falcon.

New 1reland, New Guinea, Duke of York I. \& New

Hanover.

Wing ad. $12.50 \mathrm{in.}$; hind neek much darker grey; throat and chest light ashy grey, but chest with broad tips of rusty rufous, obseuring the grey; below elosely and broadly

* Said to be a synonym (c). Ogilvie Grant. Tbis, Suppl.. ii., p. 270, 1915), and $B$. s. stenozona Gray, from Aru Is., seems non-separable. 
barred with light misty rufous; under taileoverts buffy rufous.

261g. Baza suberistata mfa Schl., Tög. Ned. Ind. N. Molueca Valkrög., p). 41, 78 (1866). [Halmahera, ete.] Islands Rufour ('nekoo-Faleon.

(Halmahera, Morotai, Batchian, Ternate, ete.).

\section{Gen. IXXVIII. HENICOPERNIS Gray (1859).}

Wings falling mueh short of end of tail; tail very long, more than five times !ength of tarsus ; head slightly crested.

Size large ; wing 우 17.30 ; tail 11.5in.; ô wing 14.20-14.50 in.; above ashy brown, broadly barred with black, exeept on lower back and mimp; head and hind neek streaked with hlackish and much varied with white; tail with 5 broad black bands; below creamy white, with broad streaks of dark brown on throat and breast, narrowing below; cere and bill bluish white, tip of latter blackish; feet vellowish white; iris orange vellow.

262. Henicopernis Tongicanda longicanda "(Garnot), Toy. Coq., i., p. 58s, pl. 10 (1:26). [Dorey, Dutch. Neu Guinea, type in Paris Mus.] Long-tailed Kite.

New Guinea, Salawati, Misori I., Waigion, Aru Is.

Size similar ; wing ô 14.-14.20 in.; much darker; wing-coverts and upper seapulars dark bromn instead of banded with light and dark brown ; dark bands broader and light bands narrower on wings; tail with 4 dark bands; below blackish brown witl pale edgings.

262a. Henicopernis longicanda infuscata Gurney, New Britain. Ibis, 1882, p. 128. [Blanche Bay, New" Britain, eo-type in Brit. Mus.]

Gurney's Long-tailed Kite.

Gen. IXXIX. MACHERHAMPHUS Westerm. (1851).

Head strongly erested ; bill weak and slightly keeled; loral plumes produced above half the nostril. 
Length at. 18.5; wing 14.2 ; tail 7.8 in.; black, with a chocolate brown shade; a welldefined spot above and below cye white; throat and centre of chest white : chin and a broad streak down throat, as well as sides of latter, and a tew spots on lower parts black.

263. Machcerhamphus alcinus Westerm., Bigd. tot d. Dierk., i., pt. 2, p. 29, pl. 12 (1.8.51). [Malacea, type in Leyd. Mus.]

Nalacea Pern.

Puather smaller; wing ad. 13.9 : tail 7.3 in.; above ehocolate brown; white bases of feathers conspicnous on nape; above and below eye a broad white line; throat white, with dark brown moustachial line each side below gape and a faint ecentral streak ; wing quills dark brown, banded with white below ; tail chocolate brown above, banded with pale brown, white below ; under parts white; mpper breast streaked with dark brown, lower breast and flanks dark brown mottled with white; bill bluish, black at tip; feet bluish white.

264. Machorhamphus anderssoni Gumey, P.Z.S., 186.5, p. 618 [Otjimbinque, Damaraland, type in Norw. Mus.]

Anderson's Pern.

[Not seen, doubtful form.]

264a. Macherhamphus [anderssoni] revoili Oust., Bibl. Hantes Etudes, xxxi., art. 10, p. 2 (1866). [Somaliland.]

Gen. LXXX. PERnIS Cuv. (1817).

Size large; head usually only slightly crested ; bill stouter; basal plumes not produced beyond posterior margin of nostril ; wings and tail long; tarsus short, feathered about half way down.

Wing o $15.75-16.75$; tail 11 in.; plumage variable; normaily above brown, with paler margins and black shaft-stripes; head ashy grey; nape mottled with white; wing quills darker at tips and with 2 basal dark bars, conspicuous on whitish under-side; upper

S.IV. Africa, Madagascar, B. E. Africa, Uganda, Brit. Centr. Africa.

Somaliland. 
tail-coverts barred and tipped with white; tail paler brown, tipped with white, and with 3 dark bands; below white, with brown streaks on throat, large blotehes on breast and smaller spots on Hanks and abdomen ; $f$ larger and with much less grey on head and more barred below. Imm. : head dark brown, rufous on sides and hind neck; tail more banded; below rufous brown, with distinct black shaft-streaks; later under parts become barred with white.

265. Pernis apivorus apivorus (Limn.), S.N., i., p. 91 (1758). [Europe-restr. type loc. Sweden apud Hart.]

Honey Buzzard.
Enrope, N. to Lapland, S. to Spain, N. Italy and Greece, E. to Ural and Asia Minor ; in winter S. to Africa, cas. Canaries.

E. Siberia ; in winter to S. China.
Larger; wing $918.75 \mathrm{in}$. ; head, nape and band round lower throat black, the nape mottled with white bases to all the feathers.

266. Pernis orientalis Tacz., Fame Orn. Sib. Or., i., p. 50 (in Mem Ac. St. Petersb., xxxix., 18!)1). [E. Siberia, type in Warsaw Mus. (W. Sclat.)]

Siberian Honey Buzzard.

Slightly smaller; wing (Java) ô 17.2.) in.; crest of long feathers; general colour deep chocolate brown, with black shaft lines below ; erown black ; sides of head grey and scaly-iooking: an imperfect line across lower throat black; tail with very broad central band of pale ashy brown and broad terminal and less broad sub-basal black bands, the base brown mottled with ashy and white. Immature : buffish to white below, with broader shaft-stripes.

267. Pernis cristatus cristatus Vieill., Tabl. Ene. Meth. Orn., p. 1225 (1823). [Java, type in Paris Mns. $][=P$. ptilonorhynchus and $P$. tweeddalei.]

crested Pern.
Java,

Sumatra, Malay Pen., Siam; Borneo ; Philippines 
Wing ad. (av.) 16.5 in.; erown and sides of head ashy grey; general colour chocolate brown; tail with broad terminal black band and another narrower one nearer base, the wide interspaee and basal band ashy brown; below with distinct black shaft-stripes.

267a. Pernis cristatus ruficollıs Less., Traité, p. 76 Indian (1831); Des Mlurs, Icon., pi. 14. [Bengal, Penmsula, type in Paris Mus.] $[=P$. c. ellioti. $]$ Ceylon, Indian Crested Pern.

Assam, Burma?

Smaller; length ad. 21.5; wing 14.7 ; tail $10.5 \mathrm{in}$; above chocolate brown, the head blackish; feathers of hind neek margined with rufous; lores and feathers romd eye grey; throat white, with distinct black shaft-stripes, and black monstachial and central streaks; chest tawny rufous, with broad central streaks of black; below white, barrecl with blackish brown; tail brown with 5 bars of darker brown and remains of other bars on the interspaces, the tip whitish.

265. Pernis celebensis celebensis IValden, Tr. Z.S., Celebes viii., p. 111 (IS72) [Celebes, type in $\mathrm{Br}^{\circ}$ Mus.]

Celebes Pern.

"Resembling P.c.celebensis, but with a long crest composed of one or two elongated feathers, usually measuring about $2.5 \mathrm{in}$. and colourcd black with white bases; as a rule, not so richly coloured. . the transverse banding on belly and under tail-eoverts brown and white, not black and white, and black on nnder wing-coverts also paler.'

268a. Pernis celebensis steerei W. Sulat., Bull. B.O.C., xl., p. 41 (1919). [San Antonio, Negros, type in Brit. Mus.]

Philippine

Is. (1)

Samar,

Negros,

Mindanao,

Basilan.) 




\section{SYNOPTICAL LIST OF THE}

\section{ACCIPITRES}

(Diurnal Birds of Prey)

\section{PART IV.}

(Falconine and Pandiones)

Comprising described Species and Subspecies, with their Characters and Distribution

BY

\section{H. KIRKE SWANN, F.Z.S., M.B.O.U.}

Corresponding Fellow of Amer. Orn. Union.

\section{LONDON :}

John Wheldon \& CO., 38, Great Quenn Street, KINGSWAY, W.C.2 

A

\section{SYNOPTICAL LIST \\ OF THE}

\section{ACCIPITRES}

(DIURNAL BIRDS OF PREY)

\section{PART IV.}

Sub. Fam. VII. FALCONINE.

Bill short, eurved from the base, with one distinct tooth near the end of cutting edge of upper mandible; nostrils usually circular with central tubercle; feet strong; tibia much longer than tarsus; toes long, talons curved and sharp: tarsus short, usually reticulated ; wings long and pointed; size moderate, or small.

Gen. LXXX. MICROHIERAX Sharpe (1874).

Nostrils perpendicular ovals, without central tubercle; tarsus covered with broad scales in front and feathered nearly half way down; wings proportionately shorter than in Falco.

Size very small ; length 5.5 ; wing o 3.90 4.25 ; 우 $4.10-4.40$ in.; above greenish black; forehead, broad stripe above eye and down sides of neck, as well as collar on hind neck, white; primaries barred with white on inner webs; tail with 5 or 6 white bars on inner webs, basal one concealed and subterminal one either obsolete or a tiny spot; below entirely ferruginous, darkest on throat, vent and thighs and 
paler on chest; sides of breast greenish black. Immature with stripes on sides of head rufous, instead of white, and throat, chest and breast white.

265. Microhierax cremlescens carulescens* Linn., S.N. i., p. 88 (1758) [ex. Edwards-"Asia" = Bengal]

Himalayas to Bhutan. Red-breasted Pigmy Falcon.

Wings shorter ; 3.75 ; $\$ 4.10$ in. ; throat vent and thighs only ferruginous, chest and breast silky white, the latter slightly washed with ferruginous; tail with the subterminal white band in the form of two fair-sized spots of white, much larger than in last form.

265a. Microhierax ccerulescens burmanicus subsp. nov. [othayetmyo, Burma, E. IV. Oates, Hume Coll. 1871. Brit. Mus. Reg. No. 85, $8,19,2195$ ] White-breasted Pigmy Falcon.

Burma, Siam, Cambodia, S. Annam.

Size of $M$. c. carulescens; wing ô 3.50 , 우 4 in.; without the white collar on hind neck; no white eyebrow but sides of neck with a white patch; cheeks and ear-coverts forming a large rounded patch of black; chest white; abdomen and under tailcoverts pale chestnut, the longer under tailcoverts and whole flanks glossy black ; tail with 5 or 6 white bars on inner webs, first one concealed; wing quills spotted rather than barred on inner webs.

* This is quite certainly the correct name for this species. Edwards's plate accurately represents the Indian form except for the white neck bancl, a point which has given rise to much discussion, but there is no doubt this is an accidental variation, as in the Brit. Mus. coll. such a bird actually exists, without a trace of white collar, from Riocour's collection. (B. M. Reg. No. 89, 5. 30, 48) marked "Malaisie," and although not of the Indian race it proves the possibility of the collar being lost. The Indian form, it should be remarked has the under parts white (except vent and thighs) when immature, but nearly uniform ferruginous when adult. The eastern form on the other hand has, when adult, only a small throat patch and the vent and thighs ferruginous, with a wash of same on breast. In a large series a good deal of variation is found in the width and purity of the white collar, and Indian examples in particular often show a strong shading of black on it. 
266. Microhierax fringillarius Drap., Dict. Class. Malay

d'Hist. Nat. VI., p. 412. pl. 5 (1824). Peninsula, ["Indes"-type loc. sugg. Malacca] Java, Malayan Pigmy Falcon.

Slightly larger; wing ot 4.30, o 4.75 ; above glossy black; forehead, narrow line above eye and down side of neck as well as entire under parts white; cheeks and ear-coverts as well as sides of breast black ; thighs white; wing quills broadly banded with white on inner webs; tail with 5 or 6 white bars on inner webs.

267. Microhierax melanoleucus melanoleucus Blyth, Jnl. As. Soc. Beng. XII., pt. 1, p. $179 *(1843)$. [Assam.]

Black and White Pigmy Falcon.

Sumatra, Sarawak.

Assam, Cachar to IndoChina?

Size similar; wing ad. 4.25 ; similar, but having an irregular white nape band and with more black on sides of body. [See pl. 8 Oiseaux de la Chine, David èt Oustalet. 1877].

267a. Microhierax melanoleucus sinensis Sharpe, Ibis, 1875, p. 254 [new name for $M$. chinensis, David, Bull. Soc. Philom. Séance 27 Fevr. 1875, (Kiangsi)].

Size of $M$. fringillarius; (wing ad. $t$ in.): greater part of crown as well as forehead white; region round eye black; cheeks white; no white stripe on sides of neck; below paler than in $M$. fringillarius; but sides and thighs black.

268. Microhierax latifrons Sharpe, Ibis 1879, p. 237 [Lawas River and Lumbidan], type in Brit. Mus.

White-headed Pigmy Falcon.

Size similar; wing o 4 , $q 4.25$ in. ; above greenish black; primaries barred with white on inner webs in $\hat{\sigma}$, uniform black in +; cheeks, ear-coverts, sides of neck

China.

N. Borneo. 
and under surface silky white, the sides, flanks, thighs and lower under tail-coverts black; tail entirely black.

269. Microhierax erythrogenys erythrogenys Vigors, P.Z.S. 1831, p. 96 [Luzon, type in Brit. Mus.]

Luzon Pigmy Falcon.

Larger; wing ô 4.30-4.45; iq 4.60-4.80 in. ; under wing-covests and inner webs of primaries uniform black in $\hat{\sigma}$; belly, vent and under tail-coverts washed with pale fulvous.

269a. Microhierax erythrogenys meridionalis Ogilvie Grant, Ibis, 1897, p. 220 [ơ Zamboanga, S. Mindunao, q Samar, types in Brit. Mus.] Samar Pigmy Falcon.

S. Philip pine Is. (Samar, Cebu, Mindanao).

\section{Gen. LXXXI. POLIOHIERAX Kaup (1847).}

Nostrils as in Microhierax; tarsus less feathered in front.

Size small; length of 7.5 ; wing 4.6 in. ; wing 94.8 in. ; + above bluish grey ; head darker; forehead, sides of face and hind neck pure white; quills and tail brown, spotted on outer and barred on inner webs with white; upper tail-coverts white, as well as entire under parts; $\mathrm{F}$, interscapulary region and scapulars deep vinous chestnut.

270. Poliohierax semitorquatus semitorquatus Smith, Rep. Expl. Centr. Afr., p. 44 (1836). [Near Latakoo, Bechuanaland]. African Pigmy Falcon.

Above with head and neck darker slaty grey; below with white bars on under surface of wings and tail broader; wings rather longer; feet stronger and stouter;

S. Africa, N. to Damaraland. 
[back chestnut brown in both sexes according to Heuglin].

270a. Poliohierax semitorquatus castanonotus Heugl., Ibis, 1860, p. 407. [Méré Belenia, White Nile].

Abyssinian Pigmy Falcon.

Larger; wing ô 5.7 in. ; ô above slaty blue with black shaft lines; no white collar on hind neck; rump and upper tailcoverts white; tail with 3 bands of white, except on central feathers; below white, with black sliaft lines, the flanks washed with grey; o head and mantle bright ferruginous red.

271. Poliohierax insignis Walden, P.Z.S., 1871, p. 627. [Tongoo, Upper Burma, type in Walden Coll.]

Burmese Pigmy Falcon.

Abyssinia.

Burma, IndoChinese Provinces.

Gen. LXXXII. SPIZIAPTERYX Kaup (1851).

Nostrils round with central tubercle; outer toe longer than inner; middle toe very short; distance between tips of primaries and tips of secondaries less than half length of tail.

Length ad. 11.5 ; wing 6.35 ; tail 5.7 in. : above ashy brown, the head blackish brown; rump and upper tail-coverts creamy white; wing-coverts with blackish central streaks and spots of white on each web; quills blackish with large spots of white; tail black, all but central feathers spotted on outer and barred on inner web with white; sides of face, eyebrow and hinder part of cheeks white; below ashy white, with blackish central streaks.

272. Spiziapteryx circumcinctus Kaup, P.Z.S., 1851, p. 43. [Chile, errore = Argentina]. Spot-winged Falcon.

Argentina. 
Gen. LXXXIII. HARPA Bp. (1855).

Size much larger ; middle toe very long. Length 우 18.5; wing 10.8-11.4; tail 8.3 ins. ; ô wing 9.8-10.3 in. ; above blackish brown, narrowly barred, except on head, which is blackish, with pale rufous; quills and tail barred with greyish white; the tail bands $\&$ in number; ear-coverts and moustachial streak black; below buffy white, the breast and abdomen with central streaks of dark brown, broader on sides, which are also ocellated with large white spots; thighs and under tail-coverts bright rusty red with dark brown shaftstreaks.

273. Harpa nova-zealandia nova-zealandia (Gmel.) S.N., i., p. 268 (1789). [ex. Lath. -New Zealand.]

New Zealand Quail-Falcon.

Smaller ; wving ô 9-9.2; ; 9.7-10.1 in. ; plumage similar; [scarcely distinguishable except by sexing].

273a. Harpa nove-zealandice pottsi, * Math. and Iredale, Ibis, 1913, p. 420. [Puroah Bay, Zealand.

N. Island.]

Bush Falcon.

New

Zealand ; Auckland Islands.

\section{Gen. LXXXIV. FALCO Linn. (1758).}

Distance between tips of primaries and tips of secondaries more than half length of tail; first and third quills equal, second longest; feet large and powerful; tarsus short, reticulated; toes long with curved and sharp claws, the outer toe rather longer than inner.

* H. australis (Hombr. \& Jacq.) being not tenable, the small form has been re-named by Mathews and Iredale. 
Length $q$ about 18 in. ; wing 13.85-14.60, ô wing 12-12.75 in. ; head, hind neck and wing-coverts blackish, as also cheeks, earcoverts and short moustaclial stripe; forehead and sides of neck behind earcoverts white; rest of upper parts bluish slate, barred or arrow-headed with blackish ; tail broadly barred with black and tipped with white; below white, with a buff tinge on breast, the chest with narrow black shaft stripes, breast spotted and belly and under tail-coverts irregularly barred with black ; bill bluish ; feet yellow. Immature blown above, with paler margins, including head; tail barred with pale rufous ; immature also without the black head and longitudinally marked below.

274. Falco peregrinus peregrinus Tunst., Orn. Brit., p. 1 (1771). [Ex Pennant-Gt. Britain.]

Peregrine Falcon.

Europe,

N. of

Mediter-

ranean ; in winter to

Africa ; cas.

Greenland.

With the black of cheeks and ear-coverts reduced to a narrow stripe and the white band behind much increased.

274a. Falco peregrinus calidus Lath., Ind. Orn. 1., p. $41(1790)$. [India.] Siberian Peregrine Falcon.

N. Asia, IV. Siberia ; in winter to India, Ceylon, China, Egypt, Cyprus, N. Africa, and Malay Archipel.

Very slightly larger; wing of 13-13,15, ? 14.60-14.80 in.; chest with a more 
reddish buff tint, and with few or no markings.

274b. Falco peregrimus anatum Bp., Geogr. and Comp. List, p. 4 (1838). [ex. Aud. pl. 16 -New Jersey.]

American Peregrine Falcon.

N. America (except N.W.) ; wintering in Southern U.S. and W. Indies ; Southern S. America ; England (cas.)

Size similar; darker above and below; the head not so black but more miform with the dark plumbeous npper parts; below more heavily and broadly banded with blackish.

274c. Falco peregrims pealei Ridgw., Bull. Essex Inst., v. p. 201 (1873). [Oregon, type in U.S. Nat. Mus.] Peale's Falcon.

Pacific

Coast of N.W.

America, from Oregon to Aleutian, Commander and Kuril Islands.

Smaller than F. p. peregrimus and with more slender feet; wing ô 11.05-11.85, 우 12.60-13.40 in. ; less heavily marked below and with the ground colour more ruddy.

274d. Falco peregrinus brookei Sharpe Ann. and MediterMag. N.H. (4) xi., p. 21 (1873). [Sardinia, ranean type in Brit. Mus. $=F$. punicus, auct.] countries Lesser Peregrine Falcon. and islands, from S. Spain to Greece, Cyprus and Asia Minor, N. Morocco 
Slightly smaller; wing ô 10.65-11.20, ㅇ 11.05-11.35 in.; duller in colour than $F$. p. peregrinus and with the dark bars on abdomen closer together.

274e. Falco peregrimus minor Schleg., Abh. Geb. Zool. \& Vergl. Anat., heft iii., p. 20 (1844). [Mtns. of Cape of Good Hope.]

$\mathrm{S}$. African Peregrine Falcon.

Africa, from Cape Colony to the

Blue Nile.

Smaller than F. p. peregrinus; wing of 12.0-13.1) in. ; below tawny ferruginous, paler on throat and sides of neck, marked on flanks, thighs and under tail-coverts with a few spots and cross bars of black.

274f. Falco peregrimus peregrinator Sund., Physiogr. Sällskapets Tidsskr. Lund. i., p. 177, taf. 4 (1837). [Indian Ocean, off Nicobar Is. 1

Indian Peregrine Falcon.

Wing ô 11.65-12 in. ; क 13.25-13.50 in., $\hat{o}$ head and nape deep black, including sides of face, cheeks and ear-coverts; interscapulary region blackish, with obsolete bars of bluish grey; rest of upper parts bluish ashy, barred with black; tail blackish tipped with white, with broad subterminal and 11 other bars of black; thioat and chest deep creamy buff, latter with a few black shaft stripes; below buffy white closely and narrowly barred with black, the sides and thighs tinged with grey; more ferruginous below and with the cross bars more irregular.

$274 \mathrm{~g}$. Falco peregrimus macropus Swains., Anim. in Menag., p. 341 (Jan. 1838). [Tasmania] $[=F$. p. melanogenys Crould. $]$

Indian

Peninsula ;

E. to $S$.

China.

E. and $\mathbf{W}$. Australia, Tasmania. Black-cheeked Falcon.

Size similar; wing ô 11.6 in. ; darker above; chest much more rufous; under wing-coverts and axillaries more closely 
bared with black, the white inter-bars more rufous ; under tail-coverts and thighs barred with bluish grey and black, instead of whitish and black.

274h. Falco peregrinus ernesti Sharpe, Ibis, 1904, p. 545. [Mt. Dulit, type in Brit. Mus.] Hose's Falcon.

Borneo,

Greater

Sunda Is.

Philippine

Islands,

NewGuinea

Fiji Islands

Slightly larger; wing o* 12 , ㅇ 13.5 in. ; entire head, including cheeks and earcoverts, hind neck, interscapulary region and least wing-coverts deep black; rest of upper parts dark bluish ashy, barred and spotted with black; tail with the apical quarter black, rest bluish ashy, barred with black; under parts marked much as in $F$. p. macropus, but the bars broader and the lower parts with a pronounced grey shade.

274i. Falco peregrimus cassini Sharpe, Ann. \& Chile, Mag. N.H. (4), xi., p. 223 (1873). [Maggellan Str. and Falkland Is.]

Cassin's Falcon.

Falkland Islands.

Immature ô [Tring Mus.]. Wing 9 in. ; above black with remains of rufous edgings: an indistinct collar on hind neck pale rufous; upper tail-coverts with broad ashy margins; tail slate, tipped buffy white and indistinctly barred with black; throat white, sides of head and moustachial patch black; below rufous fawn, narrowly striated with black.

275. Falco fasciinucha Reichen. and Neum., Orn. M.B. iii., p. 114 (1895). [Teita, E. Africa.]

Kilimanjaro Falcon.

E. Africa (Kilimanjaro district). 
Smaller than F. p. peregrimus; wing $\hat{o}$ 10.95-11.40, o $11.10-11.60 \mathrm{in}$. ; above much paler bluish grey, the cross bars fainter; crown dusky brown instead of black, the fore part tinged with rufous; entire hind neck rusty red, with some dusky mottlings; fore part of ear-coverts and cheek stripe blackish; throat and sides of neck buffish white; below pale buffy fawn, breast unspotted, but sides with a few blackish spots, becoming bars on under wing and tail-coverts. Younger birds dark brown above, with rufous margins; hind neck creamy white, tinged with rufous; below creamy white, breast and flanks streaked with brown, more broadly on the latter.

276. Falco pelegrinoides pelegrinoides Temm., Pl. Col. 479 (1830?) [Nubia] |=F. barbarus Linn.? and F. punicus Levaill. jun.] Barbary Falcon.

N. Africa

(N. of the

Sahara)

from W.

Morocco

to Esypt;

in winter

S. to

Khartoum.

Said to be darker above. [Doubtful form.]

276a. Falco pelegrinoides arabicus Erlanger, J.f.O. 1903, p. 293 [Lahadsch, type in Berlin Mus.]

Larger; wing o 12 , o 13 in. ; above lighter bluish grey; fore part of crown more rufons ; hind part of crown greyish black ; nape and hind neck clear rufous, with darker centres to many of the feathers; below buffy white, with arrow-head brown spots on centre of belly and bars on the sides; throat and chest unspotted. 
276b. Falco pelegrinoides babylonicus Gurney, Ibis, 1861, p. 218, pl. vii. [Oudh, type in Norwich Mus. $]$

Red-capped Falcon.
C. Asia,

from

Turkestan and E.

Persia to

Afghani-

stan and

N.W.India ;

Mesopo-

tamia ; in

winter S. to

India ; also

to Sudan

in Africa.

Size similar; wing $\widehat{0} 12$, ㅇ 14 in. ; forehead whitish; fore part of crown black; rest of crown and nape brick-red, with black shaft stripes; moustachial stripe, feathers round eye and band down side of neck black; above dark brown, barred, except on interscapulary region, with bluegrey, inclining to fulvous on scapulars and secondaries and more regular and paler grey on rump; tail regularly barred with fulvous grey and blackish brown; below vinous buffish, warmer on breast ; streaked on chest and slightly spotted on sides with blackish in most birds, but nearly unspotted in oldest examples.

277. Falco biarmicus biarmicusTemm., Pl. Col. livr. 55, pl. 324 (1825). [Kaffirland and Cape Colony.]

South African Lanner.

S. Africa,

N. to

Angola and

E. Africa.

Slightly larger; wing $\hat{o}$ 12.35-12.85, f 14-14.75 in.; above darker and more uniform ; nape less rufous; slightly more spotted below, but with the ground colour more buffish white, and the chest as a rule free from markings. 
277a. Falco biarmicus tanyplerus Schleg., Krit. Nubia, Uebers. ii., p. 11 (1844). [Nubia and Egypt, Abyssinia; restricted type loc. Nubia.] Arabia, Nubian Lanner.

Palestine.

Very slightly larger ; wing ô 12.90-13.60 ; o 14.35-14.85 in.; lower parts more heavily spotted with black.

277b. Falco biarnicus abyssinicus Neum., J.f.O. 1904, p. $369 . \quad$ [Shoa ; type in Tring Mus.] Abyssinian Lanner.

Abyssinia, Shoa, Gallaland, Blue and

White Niles, Sudan to Hausa land \& Togoland

Similar to $F . b$. feldeggii, but paler and less marked with blackish on crown, also slightly smaller; wing of 12.20-12.80, 오 13.35-14.25 in.

277c. Falco biarmicus erlangeri Ḱleinschm., Aquila, viii., p. 33 (1901). [Tunis and Tangier, N. Morocco, types in Kleinschmidt's coll.]

North African Lanner.

N. Africa

(Atlas

district

from Tunis

to $\mathrm{W}$.

Morocco).

Size about the same ; wing of 12.20-12.90; of 13.65-14.10 in. ; with the under parts much more heavily spotted than in $F . b$. biarmicus and the ground colour more creamy white; crown and nape creany rufous.

277d. Falco biarmicus feldeggii Schleg., in Vögel Europas von Susemihl, tafl. 8a (1843 or 1844); idem Abh. Geb. Zool. iii., p. 2-3 (1844). [Dalmatia.] European Lanner.

S. Europe (Balkan countries [not extending to Russia], S. Italy.

Larger ; wing ô 13.85-14.70, \& 15.45-16.60 in.; head pale rufous to rufous white, 
with narrow blackish shaft stripes; above earthy brown, all the feathers margined with rufous; quills with the white bars on inner webs uniting on the margins; tail barred with rufous white on the inner webs and with oval spots on the outer webs; sides of face and throat white, with dusky streaks on ear-coverts, but little indication of a blackish moustache; below whitish, the chest slightly and breast and belly thickly marked with blackish brown, more in form of bars on flanks. Immature: very little rufous on head; moustache stripe more apparent ; tail with the central feathers generally unmarked; below more heavily and longitudinally marked.

278. Falco cherrug cherrug Gray, in Hardw. S.E.

Ind. Zool. ii., pl. 25 (1833-34). [India] Europe Saker Falcon.

(Balkan

Penin. and

S. Russia);

Cyprus

(cas.)

C. Asia ; to

N.W. India and China in winter.

Size similar; more barred above with pale rufous; tail regularly and closely barred across centre feathers, not marked with oval spots.

278a. Falco cherrug milvipes Hodgs., Gray's High plaZool. Misc., p. 81 (1844) [nom. nud.]; teaux of Jerdon, Ibis, 1871, p. 240. [Umballa, Central India.]

Asia :

Hodgson's Saker.

Thibet ; Mongolia ;

Nepal ; Baluchis$\tan$; China ; in winter $\mathrm{S}$. to India. 
Smaller ; wing o 12.50-13.0, q 14-14.60 in.; feathers of crown dull rufous, with blackish brown centres; nape rather paler and mottled with black; above ashy brown, with pale fulvous margins; rump paler and clearer grey; tail ashy grey, tipped with white; the outer feathers barred on inner web with whitish ashy; below white, with narrow black moustachial stripe ; lower breast with a few dark shaftstreaks, flanks and thighs ashy brown.

279. Falco jugger Gray, in Hardw. I1l. Ind. Zool. ii., pl. 26 (1833-4). [India.] Laggar Falcon.

Indian

Peninsula ;

Baluchis-

$\tan$;

Assam.

Size similar ; wing of 12-13, o 13-14 in. ; above brown, with paler fulvous margins; crown and nape with whitish margins; tail tipped with white and all but the centre pair of feathers barred on inner webs with whitish, but outer webs scarcely spotted; below white, chest streaked and breast and belly spotted with brown, more in form of bars on flanks.

280. Falco mexicanus Schleg., Abh. Geb. Zool. heft iii., p. 15 (1844). [ex. Licht.--Mexico] Prairie Falcon.

IV. North

America,

from

S. Brit.

Columbia

to

S. Mexico.

Size small ; wing o 10.6 in. ; above ashy, with indistinct fulvous margins and blackish shaft-stripes, especially distinct on head and nape, latter of which is whitish tinged with rufous; tail with broad fulvous tip, and some obsolete black bars at apical end; below white, tinged with buff on flanks and vent, and with narrow blackish shaft-streaks, except on throat. 
$2 S 1$ Falco hypolencus Gould, P.Z.S. 1840, p. 162 (1841). [60 miles from Swan River, IV. Australia.]

Grey Falcon.

Size large ; wing ô14.3, q $\mathbf{1 5 . 8}$ in. ; general colour blackish brown; forehead and sides of head and neck and under tailcoverts mottled with white: throat white, streaked with brown; breast slightly spotted with buff; tail barred.

282. Falco subniger subniger Gray, Ann. Mag. Australia. N.H. xi., p. 371 (1S43). [Tictoria.]

Black Falcon.

Without bars on tail.

282a. Falco subniger minnie Math., Austr. Av. Rec. ii., p. 127 (1915). [Queensland.] land. Queensland Black Falcon.

Size large ; wing ô13.60-14.80, o 15.25-16 in.; head blackish grey; above dark slate grey barred with pale bluish grey: wings and tail browner, latter barred with bluish grey and tipped with white; below white with a broad slate brown moustachial stripe, the breast and abdomen with drop-shaped stripes and flanks barred; bill bluish, tip black ; feet yellow.

283. Falco rusticolus rusticclus Limn., S.N. i., p. 88 (1758). [Sweden.]

Norwegian Gyrfalcon.

N. Sweden \& Norway ; Lapland ;

N. Russia ;

$\mathrm{S}$. in winter

to middle

Europe.

Larger ; wing ô 14.5, q 16 in. ; above dark slate, barred with greyish white, the head streaked with dusky slate and buffish white; chin and throat white; below white, chest streaked and belly and sides spotted with slaty black. 
283a. Falco rusticolus islandus [partim] Brünnich, Orn. Bor., p. 2 (1764). [Iceland.] Iceland Falcon.

Iceland and S. Greenland, S. in winter to Brit. Isles, Europe and N.E.

America.

Size similar ; much darker above and below; above more sooty and with transverse markings darker; rump uniform without markings; thighs dark slaty, with buffy white transverse spots. Immature: very much darker; uniform dusky brown above.

283b. Falco rusticolus obsoletus Gmel., S.N. i., p. 268 (1789). ["Freto Hudsonis"] [ $=F$. labradorius, auct.」

Labrador Falcon.

Very slightly larger; wing ô 14.35-14.90, 우 16-17 in.; general colour white, the feathers above marked with a slaty black spot towards tip; tail pure white and head nearly so; below with slight striations on flanks only. lmmature: markings much heavier and browner; head with dark stripes and tail with transverse dark markings.

283c. Falco rusticolus candicans* Gmel., S.N. i., p. 275 (1789). ["Islandia et Scotia," errore, type loc. subst. Hartert-Greenland.] Greenland Falcon.

Labrador Newfoundland.
Greenland \& Arctic America ; in winter to Brit. Isles ; N.IV.

Europe ;

Northern

United

States.

* The Gyrfalcons visiting Canada and the Northern United States in winter appear to be dark immature birds of this form, and not F. r. rusticolus as stated in the A.O.U. Cneck List (1910). 
[Not seen]. Size slightly larger and tail longer than in F.r. rusticolus; wing of 14.7-15.5; 우 15.8-17 in. ; (Sewertz).

283d. Falco rusticolus uralensis (Sewertz. and N. Asia Menzb.) Orn. Geogr. Europ. Russl., i., from the p. 288, tab. 3 (1882). [Ural Mtns. Ural Mtns. Russia.]

Ural Gyrfalcon. to Kamtschatka and Bering Is. $\uparrow$

Wing ô 14.6; differs from $F . r$.rusticolus in having upper parts reddish brown washed with ash, under parts ochraceous with tear-shaped dark brown stripes; tail brown, tipped with pale ochreous, the two middle feathers unbarred, rest with indistinct oval transverse reddish brown spots; tarsus bare for more than half its length. (Dresser). [Not seen.]

284. Falco altaicus (Menzb.), Orn. Turkestan, i., p. 272 (1892). [Altai and Minusinsk.] Altai Gyrfalcon.

[F. lorenzi (Menzb.) a synonym.]

Mountain

ranges of Central Asia ; West

Siberia.

Size small ; wing ô 10-10.50, 우 10.75-11 in.; above dark slate grey, darker on head and paler on rump ; hinder part of cheeks and sides of neck buffy white, with well-defined black moustachial stripe below; nuchal collar reddish white; tail slate grey, all but middle pair of feathers barred on inner webs with ferruginous; below creamy white, striped on breast and flanks with black; thighs and under tail-coverts rust-red.

+ Hievofalco grebnitzkii Sewertz. and Menzb., described from Bering Island, is probably synonymous with this form. 
285. Falco subbutco suhbutco Linn., S. N., i., p. 89 (1758.) ["Europe" =Sreeden.] Hobby.

Europe ;

from Scandinavia and Brit. Isles to Mediterranean ;

W. Siberia ; in winter $\mathrm{S}$. to Africa \& N.W. India.

Size scarcely larger; above paler; below with the stripes rather smaller.

285a. Falco subbutco jugurtha Hart. and Neum., Tunis, J.f.O., 1907, p. 591. [Tangier.] $[=F$. gracilis auct.]

North African Hobby.

Algeria, Morocco:

Paler above and with slightly longer wings than F. S. subbuteo; wing of $\hat{o}$ nearly equal to wing of $q$ of typical form.

285b. Falco subbutco centralasice (Buturl.) Orn. Mitt. ii., p. 175 (1911). [Baimgol, Tianshan] $[=F$. s. cyanescens Lonnberg.]

Central Asian Hobby.

Central

Asia, S. to

Chinese

Turkestan and Assam.

Slightly larger than F. s. subbuteo; wing o about 10.75 in.; darker and more heavily marked below.

285c. Falco subbuteo jakutensis (Buturl.), Nascha Ochota, 4. 6, p. 71 (1910). [New name for his F. saluratus, type loc. TschuktschenBezirk, N.E.Siberia.]

Kamtschatkan Hobby.

E. Asia and Kamtschatka ;

$\mathrm{S}$. in winter to Japan \& N. China.

Similar to F. s. subbuteo, but smaller ; wing oै 9.40-9.75, 9 9.85-10.15 in.

285d. Falco subbuteo streichi Hart \& Neum., J.f.O., 1907, p. 592. [S. China-Swator'] Chinese Hobby.

China, from Kwangtung Prov. N. to Shensi. 
[Not seen.]

285e. Falco subbuteo erkutensis Johansen, Orn. Siberia ; Jahr., xxv., p. 83 (1915). [Irkutsk Go\%.? Irkutsk Siberian Hobby.

Govt.

Wing ô 9.60-10, o 9.75-10 in. ; sexes dissimilar; ô above dark plumbeous; tail black; below blue-grey with faint blackish shaft-stripes; thighs, vent and under tailcoverts chestnut; under wing-coverts greyish black; cere and feet brownish red; + head and neck rufous; above ashy grey, barred with darker grey; primaries barred with reddish white on inner webs; throat and cheeks reddish white; below rufous.

286. Falco vespertinus vespertinus Linn., S.N. ed. xii., i., p. 129 (1766). ["Ingria" =Prov. St. Petersburg.]

Red-footed Falcon.

E. and C. Europe, N. to Sweden and

Archangel ; IV. Siberia* Asia Minor; cas.

Brit. Isles ; in winter $\mathrm{S}$.

to Africa.

Smaller ; wing ô 9.25-9.70 in. ; $\hat{o}$ under wing-coverts pure white, instead of greyish black; feet orange; $q$ head browner and below paler rufous, the breast white broadly streaked with black, becoming bars on the flanks.

286a. Falco respertimus amurensis Radde, Reisen S. von O. Sibir., ii., p. 102 (1863). [Amur.] Eastern Red-footed Falcon.
S.E.

Siberia ; Mongolia, N. China ; in winter to India and E. Africa.

* Hartert considers F. vo obscumus Tschusi from IV. Siberia to be a synonym. 
Larger ; wing ô 12.40-12.90; 우 12-9013.35 in.; sexes dissimilar; $\hat{o}$ general colour blackish slate, browner on upper parts; outer tail-feathers slightly barred with blackish; below with a trace of rufous, but the thighs dark slate; dark slate brown above, tail barred with rufous and blackish ; hind cheeks and throat deep buff, with a conspicuous black moustachial stripe; breast buffish, becoming rufous on abdomen, striped with black ; thighs deep chestnut.

287. Falco eleonorce Gené, Rev. Zool., 1839, p. 105. [Sardinia.]

Eleonora's Falcon.

lslands of Mediterranean; $\mathrm{IV}$. Canaries ; N. Africa, Algeria to Norocco ; in winter $\mathrm{S}$. to Madagascar.

E. Africa (coast from Red Sea to Madagascar) :

Arabian

Coast.

Wing ô 8.5 , q 9.1 in. ; above slaty black ; head, cheeks and ear-coverts deep black ; throat and sides of neck creamy white, washed with ferruginous; below chestnut, 
immaculate in old birds; in younger birds heavily marked with drop-shaped spots of black.

289. Falco severus severus Horsf., Trans. Linn. Soc., xiii., p. 135 (1822). [Java.] Indian Hobby.

Burma, Malay Peninsula \& Archipel. ;

French

Indo-China.

Wing o 8.50 , क 9.0-9.50 in. ; chest usually with black shaft-stripes; above darker; tail nearly black; below darker chestnut ; quills and tail below either banded or unbanded in New Guinea birds, not always unbanded.

289a. Falco severus papuamus A. B. Meyer \& Wiglesw. Abhandl. Ber. Mus. Dresden, 1892-3, No. 3, p. 6 (1893). [S.E. Nero Guinea.]

New Guinea Hobby.

New

Guinea ; Celebes? Solomon Is. ?

Above paler; wings and tail browner slaty; inner webs always barred below with pale cinnamon, chestnut of lower parts paler, without black markings in adults. 289b. Falco severus indicus A. B. Meyer and Wiglesw. Bds., Celebes, i., p. 84 (1S98). [Calcutta.]

Central Indian Hobby.

India ;

cas. Ceylon

Wing 99.6 in. ; above sooty ; primaries and tail-coverts with rufous bars on inner webs; throat buffy white; below black, with remains of chestnut edgings; thighs chestnut, streaked with black; younger bird chestnut below, streaked with black.

289c. Falco severus religiosus Sharpe, Cat. Bds. Brit. Mus., p. 397 (1874). [Ceram, type in Ceram, Halmahera. Leyden Mus.] Moluccan Hobby. 
Wing ot 9.7, + 10.5 in. ; above slaty blue, darker on head and lighter on rump; primaries and tail barred on inner webs with rufous; hind neck tinged with rufous, forehead white; throat and sides of neck reddish white; below pale dull rufous, with a few dark shaft-stripes on breast and obsolete grey bars on flanks.

290. Falco longipennis longipennis Swains., East Anim. in Menag., p. 341 (1838). [Tasmania] Australia ; $[=F$. lunulatus Lath.]

Little Falcon.

Tasmania.

Smaller.

290d. Falco longipennis murchisoniamus Math., South and Nov. Zool., xviii., p. 252 (1912.) [E. Mid. West Murchison.]

Murchison Falcon.

Australia.

Larger than last form, and differs from typical form in its blue-grey upper surface and paler under surface.

290b. Falco longipennis apsleyi Math., Austral. Av. Rec. i., p. 33 (1912). [Melville Island.]

Northern Little Falcon.

Northern

Territory ;

N.W.

Australia.

[Not seen.]

290c. Falco longipennis hanieli Hellmayr, Avif. Timor.

Timor, p. 100 (1914). [Timor.]

Timor Little Falcon.

Wing o 8.5 in. ; above dark slate grey, blackish on interscapulary region: primaries and tail feathers dark brown, latter barred with fulvous on inner web; forehead buffy white; throat and sides of neck white, washed with rufous; below rusty red, with central streaks of black on breast and sides; under wing-coverts buff, streaked with black. 
291. Falco cuvieri Smith, S. Afr. Q. Jnl., i., p. 392 (1830). [Cafferland, near Kai River.] African Hobby.

S. and W.

Africa ;

cas. in

Egyptian

Sudan.

\section{[Not seen.]}

292. Falco pyrrhogaster Reichenow, Orn. M.B., Cameroon. xxiii., p. 25 (1915). [Cameroon.]

Wing ot 9.45 , 우 11 in. ; above black, most of the feathers bordered with slate grey; tail with 3 bars of greyish white; throat white; below chestnut, except lower breast and under wing-coverts which are black, tipped and spotted with rufous buff.

293. Falco deiroleucus Temm. Pl. Col. i., pl. 348 (1825). [Brazil.] $[=F$. aurantius Gmel., auct. 1

Orange-breasted Falcon.

South and

Central

America ;

Brazil to

Guatemala.

Size small; length ot 9-10 in.; wing ô 7.3 , ㅇ 8.9; above slaty black; tail black, tipped with white, and with 3 or 4 narrow bands of greyish white; throat and sides of neck orange rufous to white with a tinge of rufous; breast black, finely barred with white; abdomen, thighs and under tailcoverts chestnut.

294. Falco rufigularis rufigularis Daud., Traité, ii., p. $131(1800)$. [Cayenne.]

[F. albigularis Daud., a synonym.]

White-throated Bat Falcon.

South and Central America, from

Argentina to Mexico.

Wing ơ 7.85 in. ; "upper surface dark slate grey instead of black; below with breast and sides of body dark brown, not black, and much more broadly banded with white."**

* A larger series is necessary to show if this form is really separable. Paraguayan birds ( $F$. ophryophanes Salvad.) appear to me indistinguishable from typical birds, 
294a. Falco mfigularis pax Chubb, Bull. B.O.C., Bolivia. xxxix., p. 23 (1918). [Charuplaya, Bolivia, type in coll. Brit. Mus.]

Bolivian White-throated Falcon.

Wing o 7.45, ㅇ 8.45 in. ; differs from F. $r$. rufigularis in being slate colour above, with black sliaft-lines, instead of black with slightly paler margins; bend of wing white varied with buff; breast and sides of body blackish brown, instead of black, and the white bars broader.

294b Falco rufigularis petoensis Chubb, Bull. Yucatan. P.O.C., xxxix., P. 22 (1918). [Peto, Yucatan, April 1888, Salv.-Godm. coll., types in Brit. Mus.?

Size moderate; length $q$ abont 15.5: wing ô 10, o $10.5 \mathrm{in.}$; ô above dull slaîy, greyer on crown and lighter on rump; upper tail-coverts barred and tipped with whitish; tail blackish brown, with about 6 white bands; a band from behind eye round hind neck white, below which is a line of black on sides of neck; throat, chest, eår-coverts and sides of neck buffy white ; sides of breast black, barred with white narrowly; belly and vent tawny, buff ; \& larger and more richly coloured; sides of head and under parts richer tawny.

295 Falco fusco-carulescens fusco-carulcscens Vieill., N. Dict., xi., p. 90 (1817). [Paraguay.]

Aplomado Falcon.

S. and C. America, from Argentina to Mexico.

\section{[Not seen.]}

295a. Falco fusco-canulescens septentrionalis Arizona. Todd, Proc. Biol. Soc. Wash., xxix., p. 98 (1916). [Arizona.] Arizona Falcon. 
Size small; length $\hat{\jmath} 11.5$; wing of 8.25 , q 9 in. ; head and hind neck chestnut red ; above bluish slate, with remains of blackish cross bars, except on back and scapulars; tail narrowly barred with black, with a broad black subterminal band and white tips; eyebrow and moustachial stripe black; forehead, sides of head and neck, throat and chest white, with a few black shaft-lines on latter; below white thickly barred with black.

296. Falco chicquera chicquera Daud., Traité, ii., p. 121 (1800). [ex. Levaill., Bengal.] Red-headed Merlin.

Size similar ; wing ô 8.6 , 99.45 in. ; paler, more barred above, especially on back and scapulars, and with bars on breast rather closer together.

296a. Falco chicquera ruficollis Swains., Bds. W. Afr., i., p. 107, pl. 2 (1837). [Senegal.]* African Rufous-necked Falcon.

Tropical Africa to South Africa.

Size small; length of about 11 in. ; wing 8 , ㅇ wing 8.5 in. ; o above dark to pale slate colour, with distinct black shaftstripes, the head and wing-coverts darker : hind neck mottled with rufous buff ; upper tail-coverts paler grey; tail tipped with fulvous and crossed with 3 black bands, and broad subterminal one; forehead, cheeks and throat fulvous, with narrow streaks of black, except on latter; below ochraceous buff, with dark brown shaftstreaks, broadest on the flanks; $q$ much browner above; tail umber brown with 4 buffish white bands.

* Falco horsbrughi, Gunning and Roberts, Ann. Tra:ıs., Mius. iii., p. i Io (I9II), [Pretoria], is a synonym of this species, a fact ascertained from a drawing made by Lt. Finch Davies from the type and examined by Dr. Hartert and myself. 
297. Falco columbarius columbarius Linn., S.N., i., p. 90 (1758). ["Ancrica," ex. Catesby = Carolina.]

Pigeon Hawk.
N. America

in winter

S. to

W. Indies and North. S. America.

Darker form.

297a. Falco columbarius sucklcyi Ridgw., Bull. Essex Inst., v., p. 201 (1873). [Shoalwater Bay, Washington.]

Suckley's Merlin.

N.IV.

America, Sitka to N. California.

Size similar ; wing ô 7.65-8, q 8.50-8.85 in. ; o above rather lighter slate blue, with the black shaft-lines; below rather more rufous; tail slaty blue, tipped with white and with broad subterminal band, the other black bands nearly obsolete; o above dark brown, tail with 5 narrow pale bands; below dull white streaked with brown.

297b. Falco columbarius cesalon Tunst.,Orn. Brit. p. 1 (1771) [ex. Pennant, British Isles.] Common Merlin.

N. Europe to Brit.

Isles and Central Russia ; in winter S. to N. Africa.

Size similar; wing of 7.75-8.10 in. ; o above lighter grey ; $q$ above paler brown ; much less heavily striped below.

297c. Falco columbarius insignis (Clark), Pr. Asia ; U.S. Nat. Mus., xxxii., p. 470 (1907). Turkestan [Fusan, Korca.]

Asiatic Merlin. to China, Japan and Ussuriland; in winter to Cyprus, Syria, India, S. China. 
Slightly larger; wing ô 8.25 in.; above still paler grey and below with smaller and paler stripes; $q$ paler generally.

297d. Falco columbarius pallidus (Suschk.) Bull. B.O.C., xi., p. 5 (1900). [W. Kivghissteppe.] Pallid Merlin.

Kirghis-

steppe ; in winter to Turkestan and N.W. India

Larger ; wing ơ 8.90, ㅇ 9.85 in.

297e. Falco columbarius lymani Bangs, Bull. M.C.Z., liv., No. 16, p. 465 (1912). [Tschegan-Burgazi Pass, Altai Mtns.] Altai Merlin.

Wing o 7.70 , 99 in. ; ô above earth brown, with greyer centres and black shaft-lines to all the feathers; tail with 5 bands of ashy white and tipped with the same; below buffy white, striped with ochraeous brown, broadest on the flanks; o more similar to $\hat{0}$, but the feathers of upper parts with ochraeous spots.

297f. Falco columbarizs richardsoni Ridgw., Gt. Plains Proc. Acad. Nat. Sci. Philad., 1870, p. 145 (1871). [Mouth of Vermilion River, $S$. Dakota.] Richardson's Merlin.

E. Asia,
(Altai
Mitns.) of W.North America ; Saskatchewan Valley to N. Dakota, in winter to N.IV.

Mexico.

Gen. LXXXV. IERACIDEA Gould (1837).

Distance between tips of primaries and tips of secondaries less than half length of tail; tarsus transversely plated bear base of toes, and appreciably longer than in Falco. 
Size moderate; wing ô $13 \mathrm{in.,} \mathrm{of} 14 \mathrm{in.}$; above sandy brown, most of the feathers edged with rufous; head with blackish shaft-stripes; tail ashy brown, tipped with white and barred with rufous; below creamy white with brownish shaftstreaks, and a dark brown moustachial stripe; thighs, axilliaries and inner lower wing-coverts chestnut.

298. Ieracidea berigora berigora Vigors \& Horsf., Trans. Linn. Soc., xv., p. 184 (1827). [New South J'ales, types in Brit. Mus.] Striped Brown Hawk.

Interior of S. Queensland and N.S. Wales.

Less rufous above, more uniform darker brown, without shaft stripes; below without shaft-stripes, the sides blackish brown, often uniform blackish brown.

298a. Icracidea berigora orientalis Sharpe Cat. Bds. Brit. Mus., i., p. 422 (1874). [New S. W'ales, ex. Schl. Naum. 1855, p. 254.]* Brown Hawk.

Coastal districts of S. Queensland and N.S. Wales, Whole of Victoria.

Smaller; wing (sex ?) 12.85 in. ; above brown with buffy tips.

298b. Ieracidea berigora tasmanica Math., Bds. Tasmania. Austr., v., p. 276 (1916). [Tasmania.]

Tasmanian Brown Hawk.

Smaller.

298c. Ieracidea berigora occidentalis Gould, P.Z.S. 1844, p. 105. [Perth.] S. IV.

Western Brown Hawk.

Wing + 14.50 in. ; dark phase; above and below smoky black or fuliginous brown.

* For the forms of this group, all very doubtfully distinct, see Mathews's Birds of Australia. 
298d. Ieracidea berigora kempi Math., Bds. Cape York, Austr., v., p. 277 (1916). [Cape York]. North Kemp's Brown Hawk.

Australia.

Above dark rusty brown; cheeks black.

298e. Ieracidea berigora melvillensis Math., Austral. Av., Rec., i., p. 34 (1912). [Melville Is.]

Northern Brown Hawk.

Northern

Territory,

N.IV.

Australia.

Very pale race.

298f. Ieracidea berigora centralis Math., Bds. Central Austr., v., p. 277 (1916). [Central Aus- Australia. tralia.]

Central Australian Brown Hawk.

[Not seen.]

298g. Ieracidea nova-guinea A. B. Meyer, J.F.O., S.E. New 1894, p. 89. [S.E. New Guinea.] New Guinea Brown Hawk.

\section{Gen. LXXXVI. CERCHNEIS Boie (1826).*}

With the general characters of Falco, but wings not so long and 3rd primary nearly equal to 2 nd ; outer and inner toes equal. (Plumage always rufescent ; sexes usually dissimilar).

Size small ; wing of 9.10-9.75, tail 6.256.50 ; wing 우 $9.65-10.25$, tail $6.50-6.75$ in. ; to above brick-red, with a few arrow-head black markings, especially on the inner secondaries; head and neck blue-grey,

* Against the opinion of many systematists I feel it desirable to separate this group from Falco, not only because they form a natural group, distinctive in colouration, but also because this group contains within it certain groups of species, closely connected, but having many ramifying forms, which it seems undesirable to treat of under Falco. 
with narrow black shaft lines; primaries dark brown, notched with white; lower back, rump and tail blue-grey, the tail with broad subterminal band of black and tipped with white; below pale rufous fawn, chest with black streaks, becoming spots on flanks; thighs rufous buff, throat and under tail-coverts buff, unspotted; ? above entirely rufous, banded with black, with only a bluish shade on rump; tail rufous barred with black; below paler.

299. Cerchneis tinnuncula timnuncula Linn., Europe, S.N., i., p. $90(1758)$. ["Europe" =Sweden.] from $68^{\circ} \mathrm{N}$. Common Kestrel.

in Scandinavia and $61^{\circ} \mathrm{N}$. in Russia to Mediterranean and N.W. Africa ; Brit. Isles ; W. and $\mathrm{C}$. Asia ; in winter to Africa and India.

Below deeper and warmer than in typical form; which it quite equals in size.

299a. Cerchneis timnuncula mpicolaformis Brehm, Vogelfang, p. 29 (1855). [ex. Württemberg Egypt, Nubia. MS.- "Egypt and Germany"; restricted type loc. Egypt.]

Egyptian Kestrel.

Larger and averaging paler above and below; wings and tail longer, the latter especially much longer than in other forms; wing क 9.85-10.10, q 10.20-10.50; tail ơ 6.75-7.75, q 7.0-8.0 ins. 
299b. Cerchneis tinmuncula dörriesi subsp. nov. [ô Sidemi, E. Siberia, Dörries coll. June 2nd, 1884, Tring Mus. ; q Amur River, E. Siberia, Dörries coll., Mar. 27, 1894, Brit. Mus. Reg. No. 97, 10, 30, 258.]* Siberian Kestrel.

Siberia

(AmurRiver to Yeneisei) and

Mongolia ;

S. in winter

to India,

Ceylon,

Assam,

Burma and

China.

Smaller; wing ơ 8.50-8.90, ㅇ 8.90-9.50 in.; much darker above and below.

299c. Cerchneis tinnuncula canariensis Koenig, J.f.O., 1889, p. 263. [Canary Is.] Canarian Kestrel.

W. Canary

Islands

(Tenerife,

Gran

Canary,

Hierro,

Palma,

Gomera) ;

Madeira.

Size similar ; wing ô 8.8 , ㅇ 9 in. ; a dark form approaching the last.

299d. Cerchneis tinnuncula neglecta Schleg., Mus. Pays-Bas, Rev. Accipitres, p. 43 (1873).

Cape Verde [St. Vincent.]

Cape Verde Kestrel.

Wing o 8.40-8.90, o $8.90-9.90$ in. ; above as pale as in C.t. timnuncula, below deeper rusty.

299e. Cerchneis tinmuncula dacotice Hart., Vög. Canary Is. Pal. Faun., p. 1086 (1913). [Lanzarote.] East Canarian Kestrel.

(Fuertaventura, Lanzarote.)

* Material from Siberia being very meagre, I have principally determined this form from the considerable number of large and long-tailed birds, always on the pale side, existing in collections from Ceylon, India, Assam, etc., which are obviously migrants from the north, and have no connection with the smaller and darker form breeding in N. India (C.t. saturala), with the rather darker but nearly typical bird breeding in W. Asia, or with the darker but large race breeding in Japan $(C, \ell$. japonica). A large immature of bird in my collection from Ceylon has a tail measurement of 7.75 in. and there are birds in the Tring collection with nearly the same measurement. 
Larger ; wing ô 9.5()-9.75, क 10.(1)-10.55 in. ; head darker than in C.t. tinmuncula ; dark spots on mantle larger and with broad dark shaft-marks to the feathers; below darker than C. c. timmuncula.

299f. Cerchncis timmucula japonica Temm. and Schleg., in Siebold's Fauna Jap. Aves, p. 2, pl. 1, and 1b. (1844). [Japan.] Japanese Kestrel.

Japan :

$\mathrm{S}$. in winter to China \& Hainan.

Rather smaller ; wing of 9.10-9.50, tail 6; wing o 9.50-10 in.; smaller and much darker than C.t. timmucula; much deeper rufous above and more heavily spotted; head and tail showing a great tendency to a rufous wash, and tail more generally with remains of black bars even when adult; chest more heavily striped and breast with larger spots.

299g. Cerchneis timnuncula saturata (Blyth) Jnl. As. Soc. Beng., xxviii., p. 277 (1859). [Tenasserim.] Himalayan Kestrel.

Mountains of N. India

to China ; in winter S. to Travancore ; cas. Ceylon?

Smaller than C.t. timmuncula; wing o 8.709-45 in. ; dark form approaching saturata. 299h. Cerchneis tinnuncula carlo Hart \& Neumann, J.f.O., 1907, p. 592. [Bissidino near Harrar, type in Tring Mus.]

Central African Kestrel.

Tropical Africa (Somaliland, Abyssinia and Blue Nile to Victoria Nyanza \& Tanganyika) ; S. Arabia. 
Size of C.t. timmuncula; wing ô 10 in. ; similar in general colouration, but with sides of face dull blue-grey like head; q tail blue-grey banded with black, instead of rufous.

299i. Corchneis timnuncula rupicola Daud., Traité, ii., p. 135 (1800). [ex. Levaill.—Cape of Good Hope.] South African Kestrel.

S. Africa, (Natal,

Cape

Colony, Damaraland).

Smaller ; wing ot 8.70-9.20, $q$ 9-9.60 in. ; ot above deep bay, with broad arrow-head markings of black; head and hind neck uniform, streaked with black; rump, upper tail-coverts and tail bluish grey, latter with broad black subterminal band and white tips; throat rufous white; below bay colour, streaked on breast and arrow-headed on flanks with black; 우 more banded above; tail with extra dark bars, besides the subterminal one.

300. Cerchneis molucconsis moluccensis Hombr. \& Jacq., Voy. Pole Sud. Zool. Atlas, pl. 1., f. i. (1842) et texte iii., p. 46 (1853). [Moluccas?]

Moluccan Kestrel.

[C.t. orientalis a synonym.]

Molucca Is. (Amboyna, Bouru, Ceram, Goram, Peling Is., Halmahera, Morotai, Ternate, Batchian).

Smaller; wing ô 7.85 (Celebes) -9.20 (Java), 우 (Flores) 9 in. ; paler, with more greyish cheeks and ear-coverts, much whiter under wing-coverts and lighter underside.

300a. Cerchneis moluccensis occidentalis A. B Celebes, Meyer \& Wiglesw., Abhandl. Ber. Mus. Lesser Dresd. 1896-7, No. 2, p. 8. [Celebes.] Javan Kestrel.

Sunda Is. to Kangean; Java. 
Size similar; wing ô 9.3 , ㅇ $9.8 \mathrm{in.} \mathrm{;} \hat{o}$ above pale rufous, almost unspotted; head pale bluish grey, washed with rufous, and with black shaft-lines; rump and tail blue-grey, latter with broad subterminal black band and white tips; sides of face greyish white; below buffish white, the chest tawny buff, that and sides with black shaft-stripes; under wing-coverts white; o head and tail like back, the tail barred with black.

301. Cerchneis cenchroides cenchroides Tig. and Horsf., Trans. Limn. Soc., xv., p. 183 (1827). [N. S. Wales.]

Nankeen Kestrel.

301a. Cerchneis cenchroides milligani Math., Nov. Zool., xviii., p. 253 (1912). [Parry's Creck, N.W.Australia.]

Dusky Nankeen Kestrel.

N.IV.

Australia, Nortliern Territory.

Smaller; below darker, decided cinnamon pink ; tail rusty cinnamon.

301b. Cerchneis cenchroides unicolor Milligan, Emu, iv., p. 1 (1904). [Yalgoo.] Westralian Nankeen-Kestrel.

East

Australia.
S.W. and Mid. W'. Australia.

Larger; wing ô 11, +11.4 in. ; tै above tawny rufous, with broad cross-bars of black; head uniform, but streaked with black; rump and upper tail-coverts black ish, barred with fulvous; tail ashy rufous, banded with black, the subterminal band broad, followed by a white tip ; primaries blackish brown, the inner ones mottled with rufous on inner webs and spotted on outer webs; below dull tawny rufous, breast streaked with brown, flanks more heavily marked; under wing-coverts white; $q$ similar, but flanks more barred. 
302. Cerchneis rupicoloides rupicoloides Smith, S. Afr. Q. Jnl., i., p. 238 (1830). [Groene River, Little Namaqualand, type in Brit. Mus.]

Larger African Kestrel.

Smaller, much paler above.

302a. Cerchneis rupicoloides fieldi Elliott, Field Somaliland. Columb. Mus. No. 2 Orn., p. 58 (1897). [Somaliland.]

Somali Kestrel.

Rather darker, tail with narrower black bars, the pale ones more blue grey.

302b. Cerchneis rupicoloides arthuri (Gurney). Brit. E. List Diurn. Bds. Prey, p. 156 (1884). Africa [Mombasa.]

East African Kestrel.

Wing ô 10.6 in. ; plumage above and below fox red; head narrowly and back and wing coverts more broadly streaked with black; the greater wing-coverts with remains of bars; primaries black, margined and tipped with paler red; tail darker red, witl about 15 bars of black; throat unmarked, but rest of under surface with narrow central streaks of black.

303. Cerchneis alopex alopex (Heugl.) Syst. Uebers., p. 10 (1856), and Ibis, 1861, p.69, pl. iv. [prov. Galabat.] Fox-coloured Kestrel.

South

Africa.

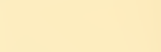


Smaller ; wing ô 7.4, o 8.2 in. ; ô above, including head and neck, light rufous, streaked on head and neck and arrowheaded on scapulars and wing-coverts with black ; rump and upper tail-coverts dark bluish grey with more or less of black arrow-head markings; tail bluislı grey banded with black, the subterminal band very broad; forehead, sides of head and under parts creamy white, tinged with rufous on chest, which is marked with elongated black spots, becoming more oval on breast and flanks; under wing-coverts white, streaked with black; o similar.

304. Cerchneis newtoni Gurney, Ibis, 1863, p. 34, pl. 11. [Madagascar.]

Madagascar Kestrel.

Size similar; wing 07 , +7.6 in. ; above dull foxy rufous, with rather broad bars of black; head with blackish shaft-stripes; tail deep bay, with 6 bands of black; below white, with large oval spots of brownish black, smaller and more longitudinal on flanks; q similar.

305. Cerchneis punctata Temm., Pl. Col., i., pl. 45 (1823). [Isle de France.]

Mauritius Kestrel.

Smaller; wing ô 5.6, o 6.3 in. ; ô above maroon-chestnut, with a few black shaftlines and spots, chiefly on wing coverts and scapulars; rump, upper tail-coverts and tail bluish grey, latter with broad subterminal and 4 other black bands; head dark bluish grey; sides of face paler ; below isabelline fawn colour, unspotted; o scarcely differs.

306. Cerchneis gracilis (Less.) Traité, p. 93 Seychelles (1831). [Seychelles].

Seychelles Kestrel.
Madagascar.

Mauritius. Is. 
Size small ; wing of 9.10-9.70, ㅇ 9.10-9.80 in. ; ot head, hind neck, rump, upper tailcoverts and tail blue grey, latter tipped with white and with broad subterminal black band ; rest of upper parts cinnamon rufous, unspotted; greater wing-coverts and inner secondaries blue grey, shaded with rufous externally; primaries dark brown; throat whitish ; chest and breast pale cinnamon, marked with small black spots, larger on the flanks, abdomen and under tail-coverts yellowish white; 우 more like that of $C$. $t$. tinmmincula, but smaller and distinguished by its white claws.

307 Cerchneis naumanni naumammi Fleischer, Sylvan, 1817-18, p. 174 (1818). [S. Germany and Switzerland.]

Lesser Kestrel.

Mediter-

rannean

countries, from Spain

to $\mathrm{S}$.

Russia, also N.W.

Africa :

Asia Minor, Cyprus and S.W. Asia ; in winter to Africa ; cas. in Central Europe and Brit. Isles.

Size similar ; wing ô 9.6 in. ; darker above and below, and without spots below when adult, or with minute spots on sides when less mature ; wing-coverts almost entirely blue-grey, only innermost ones slightly washed with rufous.

307a. Cerchneis nanmanmi pekinensis Swinh., N. China ; P.Z.S., 1870, p. 442. [Pekin.] Himalayas? Chinese Lesser Kestrel. 
Slightly smaller; wing ô 9 in.; above with red of mantle very much paler; below paler fawn colour and uniform without spots, except a few on sides in less mature birds.

307b. Cerchneis nammanni turkestanicus Zarudny, Mess. Orn., 1912, p. 114. [Russian Turkestan.]

Turkestan ;

$\mathrm{S}$. in

winter to

Somali-

land.*

Length ad. 10-11, wing 7.50-8.00 in., tail 5-6 in.; head slaty, crown usually rufous; above rufous, more or less barred with black (according to age); tail with subterminal band of black and white tips; outer feathers more or less white, with one or more extra partial bands of black on inner webs (according to age); below buffish white, the chest pale cinnamon fawn, more or less finely spotted with black on sides of body (according to age). [Specific distinctions: crown generally rufous; chest washed with rufous; sides spotted.] $\dagger$

* I have described this form from a presumed typical ô from Samarkand, May Ist, 1908 , alt. 2,000 ft., D. Carruthers coll., in the Brit. Mus. coll. An example in the Brit. Mus. coll. from Somaliland, very pale and unspotted below, is as pale above as the Samarkand bird and is evidently referable to this form ; the line of migration to N.E. Africa being a quite natural one. Examples from Central and S.E. Africa are however $C$. n. namanni.

+ Opinions differ greatly as to the specific and subspecific value of the American Kestrels, but I think it desirable to give specific rank to the typical race of each of the three groups of forms, and I have pointed out the principal characters on which I base these species. Some ornithologists appear to me to have failed to grasp the most important factors in determining the subspecies of these groups of forms, and to have attached undue importance to tail markings and the spotting of under parts, characters which vary with maturity and require to be considered with great caution. The spotting below is common to the less mature birds of all three groups, but disappears with age entirely in the isabellina group and varies in the other two, while the rufous on crown is likewise common to all three when immature, but disappears in the isabellina and cinnamomina groups, yet is usually retained in the sparveria group. The markings of the onter pair of tail feathers and the width of the subterminal tail band are most unreliable characters in themselves, as a series of old and young of both sexes in my collection from one district in Venezuela shows. 
308. Cerchneis sparveria sparveria Linn., S.N., United i., p. 90 (1758). ["America," ex. Catesby =- States, Carolina.]

American Kestrel.

E. of Rocky Mtns.; S. in winter to Florida and Gulf States.

Smaller; wing ô 7.50, tail 5.25 in. ; appreciably paler; tail relatively longer and paler; wing-coverts less spotted; rufous crown patch appreciably larger; below with larger, rounder and more numerous black spots; chest cinnamon fawn.

308a. Cerchneis spareria phalana (Lesson), Echo du Monde Savant, Ann. 12, June 19, p. 1086 (1845). [Mexico.]

Western Kestrel.

Western

North

America, from

E. Brit.

Columbia

and $\mathrm{W}$.

Montana to

N.II.

Mexico ; in winter S. tc. Mexico and Guatemala

Southern

Lower

California.

Smaller; wing ơ 7-7.50 in. ; under parts nearly immaculate in old birds, the ground colour either cinnamon fawn or nearly white; throat white. 
30Sc. Cerchneis spareria paulus Howe and King, Contr. N. Amer. Orn., i., p. 28 (1902). [Florida.]

Florida Kístrel.

Florida, Peninsula ; Bahama Islands.?*

Size small ; wing ad. 6.9 in. ; above more heavily banded with black, the tail barred broadly with black even when mature, but bars obsolete on central feathers in some examples; bclow creamy white, chest washed with fawn, with large black spots on breast and sides.

308d. Cerchneis spareria carribbaram Gmel., S.N., i., p. 284 (1788). [ex. Briss. "Antilles," type loc. sugg. Dominica.] Antillean Kestrel.

\section{Lesser}

Antilles

(St. Lucia,

Dominica,

Guada-

loupe,

Antigua,

Montserrat,

Anguilla,

Virgin

Gorda, St.

Thomas) to

Porto

Rico.†

Wing ò 6.80 in.; head slate, usually wihout rufous on crown, and black bands on back nearly absent; below white, unspotted in oldest birds, or with a few black spots on sides in less mature; inner webs of primaries white, the black bars nearly obsolete; q with bands above narrower than in typical form; below much whiter, slightly streaked on sides of breast with pale brown.

* I am unable to say definitely what race inhabits the Bahama Islands, not having seen examples.

+ I am unable to separate the Porto Rico race [Cerchneis sparveria loquacula Riley, Smith. Coll., xlvii., p. 284, I904; I'ignes I.] as so far as the scanty material available shows it is not distinguishable from caribb a amm.

+ Almost dead white in Cuban birds, with scarcely any colour on chest, but two San Domingo examples seen have a strong cinnamon shade on chest; as they show one or two spots on sides they are apparently younger birds. 
308e. Cerchneis sparveria dominicensis Gmel., S.N., i., p. 285 (1788). [S. Domingo]. St. Domingo Kestrel.

Wing o 7.25 ; tail 5.25 in. ; above darker than C. s. phalana, especially tail; back more heavily banded with black; tail band slightly broader; head darker slate, either without rufous, or with a small and indistinct nape patch; below creamy white, including the chest, and much more heavily striped on chest and spotted on breast and sides with large black spots; thighs and vent unspotted.

308f. Cerchneis sparveria guatemalensis* subsp. nov. [ơ Capetillo, Guatemala, J. J. Rodriguez, in coll. H. Kirke Swann ; o Huehuetenango, Guatemala, June, 1897, W. B. Richardson, in coll. Brit. Mus., Reg. No. $98,12,1,91$.

Central American Kestrel.

Central
America :
Guatemala,
Brit.
Honduras,
Honduras,
Nicaragua,
Costa
Rica ;
Mexico
(cas. ?).

Larger; length ad. about 11 in. ; wing $\hat{o}$ av. 7.80 , tail 5.50 in. ; ot with no rufous on crown; q usually with partial crown patch ; o tail with one narrow (av. $13 \mathrm{~mm}$.) black subterminal band and white tips mixed with rufous; the tips of central pair and inner webs of outer pair of feathers rufous; below white, chest with decided tinge of fawn, and with large black rounded spots on sides; $q$ with much narrower (almost linear) bands on

S. Domingo and Cuba. 
tail-coverts and tail, which is much paler; below whiter with narrower and paler stripes [Specific distinctions: $\hat{\sigma}$ slate crown without rufous, pale chest, and spotted under parts ; o narrower and more regular bars on tail-coverts and tail.]

309. Cerchneis cinnamomina cimnamomina Swains., Animals in Menag., p. 281 (1838). [Chile.]

Cinnamon Kestrel.

Southern

S. America :

Chile ;

Argentina

(except

N.E. $)^{*}$;

S. Peru,

IV. of

Andes (?) ;

Patagonia

to Straits

of Magellan

Slightly smaller; wing o av. 7.10, tail 5 in.; tail with the subterminal black band appreciably wider (av. $22 \mathrm{~mm}$.); sides moderately spotted with black; q tail darker red, and with broader, straighter and more complete cross-bars, the subterminal one broader ; below with broader and darker brown stripes.

309a. Cerchneis cinnamomina anstralis Ridgw., Pr. Acad. Nat. Sci. Philad., 1870, p. 149. [Paraguay, type in U.S. Nat. Mus.; new name for Falco gracilis (nec Lesson) Swains., Anim. in Menag., p. 281, 1838, Bahia, Braz., type in Brit. Mus.] Brazilian Kestrel.

Brazil,

N. to

Amazon

River (?),

S. to N.

Argentina.

E. to

Paraguay

and the

eastern

slopes of

Andes in

Bolivia and

Peru.

* Line of demarcation in Paraguay, Bolivia and S. Peru uncertain. 
Size similar ; wing o $7-7.50 \mathrm{in.} \mathrm{;} \mathrm{tail} 5.25$; ㅇ wing 7.25-7.5 in. ; o head much darker, blackish slate; above darker rufous; tail band $18.22 \mathrm{~mm}$. (central widest, northern and southern narrowest) ; below much deeper cinnamon; spots on sides fewer (except in less mature birds); q above (including tail) and below much darker cinnamon rufous; wing quills washed with rufous on inner webs, the black bars much narrower and white interspaces $6 \mathrm{~mm}$. wide; tail bands narrow and regular as in C. s. cimamomina, but underside much less white and bars appearing much narrower, with no black terminal band.

309b. Cerchneis cimnanomina equatorialis Mearns, Auk., 1892, p. 269. [ơ"Gmayaquil,", errore =interior of Equador, type No. 101, 309 in coll.•U.S. Nat. Mus.]

[C. c. canca Chapm. and C. c. andina Cory, synonyms.]* Andean Kestrel.

Ecuador.

N. to West Colombia (IV. slope of central and northern Andes).

Slightly larger; wing ot 7.50 in.; more deeply coloured and more heavily marked; vent and under tail-coverts clear buff;

* I think that the absence of exact locality for Mearns's type cannot be held to disqualify his name, as it seems certain the example came from some part of Ecuador, and I accept "interior of Ecuador" as a sufficient locality, since $1 \mathrm{am}$ unable to distinguish four (?) separate races for Ecuador as set forth by Cory (Field Mus. Pub. Orn., Ser. i., pp. 319-23). C. c. canc a appears to me to be a northern extension of this dark form, reducing in size slightly ; C. c. andina appears to rest on the largest and darkest birds, with fewest spots on sides, and presumably the most mature, judging by the description and by presumed examples I have seen. His $C$. c. permviana, being the paler southern examples, is in my opinion untenable, as most Peruvian birds can be referred either to cimmamomina or australis. There are only two groups of forms in South America, the larger cinnamomina and the smaller isabellina. If a bird is of fair size and has spotted sides when quite adult it must belong to the former, and if small, with unspotted sides when adult, it must belong to the latter. To treat both as forms of sparveria, as Cory does, is confusing. It cannot be too strongly emphasised that the spotting in the isabellina group is immaturity ; in cinnamonina it remains in the adult, but must vary as we get away from the typical race. Andina by its size appears to belong to the cimnamomina group, and according to Cory's description the spots are not entirely absent. 
spots below larger and more numerous; ? under parts (except throat) much deeper, in some specimens dull rufous, obscurely streaked and spotted with blackislı; vent and thighs clear buff.

309c. Cerchncis cinnamomina fomandensis Chapm., Bull. Am. Mus. N.H., xxxiv., p. 379 (1915). [Masaticrra I., Juan Fernandez Is., type in Am. Mus. N.H.] Juan Fernandez Kestrel.

Smaller and paler ; ô length 9.50; wing 7 ; tail 5 in.; head and nape bluish slate, without rufous when fully ad. ; above rufous, with only one or two small specks of black; wing-coverts slate blue, slightly spotted with black; primaries with black bars more or less obsolete, not extending across webs; tail with black subterminal band 15-25 mm. wide, and white tips; outer web of outer feather white, inner rufous; below light pinkish cinnamon, unspotted (except in less mature birds); thighs and vent white; $q$ below isabelline, with a few fine'streaks and spots of pale brown on chest and sides of breast; nape often with rufous patch or tinge. [Specific distinctions: small size, slate crown, and unspotted under parts.]

310. Cerchncis isabcllina isabcllina Swains., Anim. in Menag., p. 281 (1838). [Demarara, type in Brit. Mus.]

Isabelline Kestrel.
Juan

Fernande $z$ Islands, off Cliile
Guiana and $\mathrm{E}$.

Venezuela

(E. to

Caracas,?

S. to Rio

Branco,

N. Brazil).

Length ô 9 in. ; wing 7-7.25; tail 5 in. ; q wing 7.50-7.70, tail 5.25 in. ; ô above darker rufous, with only a few black spots and bars; head blackish slate with no rufous patch when adult; primaries 
barred right across inner webs; tail with broader black subterminal band (25-30) nmm.) ; below decided rufous cinnamon, unspotted in ad. (less mature with a few black spots on sides); + and juv. $\hat{o}$ isabelline rufous below with dark brown streaks and spots; crown with more or less rufous.

310a. Cerchneis isabellina ochracca Cory, Field Mus. Pub. Orn. Ser., i., p. 298 (1915). [Colon, Tachira, W'. I'cnez., type in Field Mus.]

Venezuelan Kestrel.

Venezuela, (Merida,

Colon,

Valle,

Ohama,

Montana de

la Sierra,

Cutata,

Margarita

I.) ; N.E.

Colombia ;

Andes

region of

Colombia.*

Wing shorter; o⿱ av. 6.50, क 6.90 in. ; similar to last form but with a greater tendency to banding above and.to heavy black spotting below in less mature birds; ad. of below isabelline rufous unspotted; tail band av. $25 \mathrm{~mm}$. [Barely separable form.]

310b. Cerchneis isabellina brevipennis Berl., J.f.O. 1892, p. 91. [Curacao.]

Curacao Kestrel.

Curacao,

Bonaire, Aruba Is., off

Venezuela.

* C. i. intermedia Cory (Field Mns. N. H. Orn., i., p. 325 (19I5), seems to be non-separable. The average wing of his examples is the same as the measurement of his type of ochracea; the narrower band on the tail scems scarcely a reliable distinction, while the white spotting on outer webs of primaries is a very variable character. C. i. margaritensis Cory (T. c., p. 297), $1 \mathrm{am}$ also unable to distinguish, as examples with the paler under parts occur in the Merida district along with the darker birds. His C. i. perplexa (t. c., p. 327) I am unable to distinguish, dark and pale-breasted birds occurring together as I have before pointed out; while C. $i$. distincta (t. c., p. 297) is most certainly typical isabellina, the principal character, the obsolete bass on inner webs of primaries, being present in Brit. Guiana examples. 
Wing of 7.7-7.25, \& 7.40-7.55 in. ; head, neck, back and wing-coverts slaty blue; with a tinge of rufous on interscapulary region; rump, upper tail-coverts and tail deep bay, the tail tipped with white and with a broad subterminal bar of black; throat and sides of face whitish; below chestnut-fawn, paler on vent, and shaded with greyish on flanks, with one or two spots of black.

311. Cerchneis sparverioides Vig., Zool. Jnl., iii., p. 436 (1828). [Cuba]. Cuban Kestrel.

Cuba; cas. Florida?

Gen. LXXXVII. DISSODECTES Sclat. (1864).

With the characters of Cerchneis but with a more or less constant double-toothed mandible, and plumage not rufescent.

Wing ô 8.9 ; general plumage slaty grey (paler below) with dark shaft-lines to the feathers; tail with whitish bands on inner webs; throat and sides of face whitish.

312. Dissodectes ardosiacus Bonn. et Viell., Enc. Meth., iii., p. 1238 (1S23). [Senegal.] Slate-coloured Kestrel.

\section{W. Africa \\ (Sene- gambia to Angola) ; \\ N.E. \\ Africa, Equatorial Africa.}

Smaller; wing ô 8.3; head and neck whitish ashy, with distinct blackish shaftstripes; rest of upper parts blackish brown, the primaries darker and banded on inner webs with white; rump and upper tail-coverts white, shaded with grey; tail greyish white, banded with black, the subterminal band broad; throat whitish; under parts ashy brown. 
313. Dissodectes dickinsoni Sclat., P.Z.S., 1864, p. 248. [Shivé River.]

Dickinson's Kestrel.

(ambi

River, Nyasaland, Angola.

Wing ô 8.75, ㅇ 9.1 in. ; above ashý grey with black shaft-stripes, paler and bluer grey on rump and upper tail-coverts; scapulars and wing-coverts barred with greyish black; primaries blackish, barred with rufous or whitish on inner webs ; tail black, all but the 2 central feathers barred with greyish white; forehead and throat whitish, streaked on throat and barred below with ashy brown.

314. Dissodectes zoniventris (Peters), Sitz. k. MadaPr. Akad. Wiss. Berl., 1853, p. 7. [Mada- gascar. gascar.]

Madagascar Grey Kestrel.

Sub. Order III. PANDIONES.

Gen. LXXXVIII. PANDION Savigny (1809)

Plumage very close and compact, wanting the accessory plumule; no facial disk ; eyes placed laterally in the head; nostrils generally not concealed by bristles; tarsus reticulated; toes devoid of feathers, the under surface rough, covered with small pointed scales; the outer toe reversible.

Size large ; length ad. about 24 in. ; wing 19-20.90 in.; head white, the crown striped with blackish brown; nape feathers elongated and lanceolate; ear-coverts and stripe through eye blackish brown; above dark brown, with paler margins to most of feathers; tail dark brown, inner webs barred with dark brown and whitish ; below white, the breast varied with pale brown centres to the feathers; bill black ; feet blue. 
315. Pandion haliaëtus haliaëtus (Linn.), S.N., Europe, i., p. 91 (1758). [Europe =Sweden.] from LapCommon Osprey. land (and formerly Scotland) to the Mediterranean and Coasts of $\mathrm{N}$.

Africa and Red Sea ; S. Arabia ; N. Asia to Japan and Kamtschatka.

Size similar; dark markings of head blacker; above darker and richer brown ; less marked on under side.

315a. Pandion haliaëtus carolinensis Gmel., S.N., N. America i., p. 263 (1789). [Carolina.] American Osprey.

N. to Newfoundland and Alaska; S. in winter to Central America ;

S. America.

S. to Peru and

Paraguay.

Similar to typical race, but smaller ; wing ad. 16.50-18.25 in.; head much whiter; feet bluish white.

315b. Pandion haliaëtus cristatus (Vieill.), N.D., Australia; iv., p. 481 (1816). [Tasmania.] Whiteheaded Osprey.

Tasmania ; Moluccas ;

New

Guinea ;

Philippines;

Sunda Is. 
[Not seen]. Smaller.?

315c. Pandion haliaëtus microhaliaëtus Brasil, New Rev. Franc. Orn., 1916, p. 201. [New Caledonia. Caledonia.]

\section{Gen. LXXXIX. POLIOAETUS Kaup (1850).}

Wing ô 18, ㅇ 20.4 in. ; above brown, darker on wings, the primaries blackish; head and neck all round ashy grey; tail white, with broad terminal bar of brown ; breast brown; belly white ; under side of wing leaden brown, with a white spot at base of primaries; feet yellowish white.

316. Polioaëtus ichthyaëtus ichthyaëtus Horsf., Indian

Tr. Linn. Soc., xiii., p. 136 (1822). [Java.] Peninsula; White-tailed Fishing Eagle.

Ceylon ;

Burma ;

Peninsula

Malay

and

Archipel.

Smaller; wing 우 16.2 in.; above ashy brown, back and wings darker: tail pale brown at base, blackish brown subterminally, the tip white; throat, breast and under wing-coverts ashy brown ; belly white; feet bluish white.

316a. Polioaëtus ichthyaëtus humilis Müll. and Burma; Schl. Nat. Gescl. Zool. Aves, p. 47, pl. 6 Malay (1839-44). [Sumatra.] Malayan Fishing Eagle.

Peninsula ;

Sumatra ; Borneo; Java ; Celebes. 


$$
\text { - }
$$










\section{3 \\ 3 .}

1 $3,3,3,3$ 3,$3 ; 3$ III, 3 ,

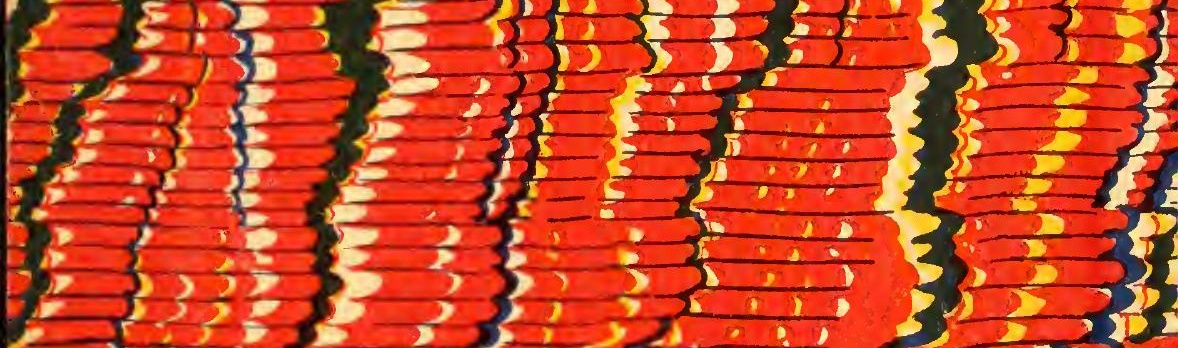
$\{, 3\}, 3,3,, \ldots, 3,3,3$ (3) $\begin{array}{ll}3 & 35 \\ 3 & 3 \\ 3 & 3\end{array}$ $\{3\}\{35=3\{3\}$ ? $3:$ \{3 $3\left\{\begin{array}{l}3 \\ 1\end{array}\right.$

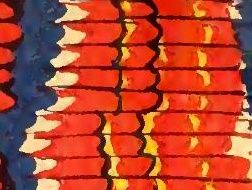
सा \}? 3,253
$3=35$

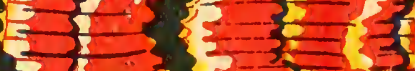
3ा: 35 ? 3

3 हर . 
